MARCELLO MACHADO

VEGF e vascularização ao longo do desenvolvimento e involução do timo em suínos 
MARCELLO MACHADO

\section{VEGF e vascularização ao longo do desenvolvimento e involução do timo em suínos}

Tese apresentada ao Programa de PósGraduação em Anatomia dos Animais Domésticos e Silvestres da Faculdade de Medicina Veterinária e Zootecnia da Universidade de São Paulo para obtenção do título de Doutor em Ciências

\section{Departamento:}

Cirurgia

Área de Concentração:

Anatomia dos Animais Domésticos e Silvestres

Orientador:

Prof. Dr. Pedro Primo Bombonato 
Autorizo a reprodução parcial ou total desta obra, para fins acadêmicos, desde que citada a fonte.

DADOS INTERNACIONAIS DE CATALOGAÇÃO-NA-PUBLICAÇÃO

(Biblioteca Virginie Buff D’Ápice da Faculdade de Medicina Veterinária e Zootecnia da Universidade de São Paulo)

T.2240

Machado, Marcello

VEGF e vascularização ao longo do desenvolvimento e involução do timo em suínos / Marcello Machado. -- 2010.

146 f. : il.

Tese (Doutorado) - Universidade de São Paulo. Faculdade de Medicina Veterinária e Zootecnia. Departamento de Cirurgia, São Paulo, 2010.

Programa de Pós-Graduação: Anatomia dos Animais Domésticos e Silvestres.

Área de concentração: Anatomia dos Animais Domésticos e Silvestres.

Orientador: Prof. Dr. Pedro Primo Bombonato.

1. Timo. 2. Vascularização. 3. VEGF. 4. Desenvolvimento. 5. Involução. I. Título. 


\section{FACULDADE DE MEDICINA VETERINARIA E ZOOTECNIA Comissno Bioetica.}

\section{CERTIFICADO}

Certificamos que o Projeto intitulado "VEGF e vascularização ao longo do desenvolvimento e involução do timo em suínos", protocolado sob o n $1510 / 2008$, utilizando 25 (vinte e cinco) suínos, sob a responsabilidade do Prof. Dr. Pedro Primo Bombonato, está de acordo com os princípios éticos de experimentação animal da "Comissão de Ética para uso de animais" da Faculdade de Medicina Veterinária e Zootecnia da Universidade de São Paulo e foi aprovado em reunião de 25 de novembro de 2009.

São Paulo, 30 de novembro de 2009

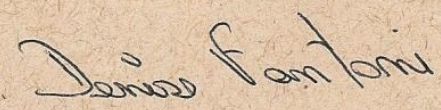

Profa Dra Denise Tabacchi Fantoni

Presidente 


\section{FOLHA DE AVALIAÇÃO}

Nome: MACHADO, Marcello

Título: VEGF e vascularização ao longo do desenvolvimento e involução do timo em suínos

Tese apresentada ao Programa de PósGraduação em Animais Domésticos e Silvestres da Faculdade de Medicina Veterinária e Zootecnia da Universidade de São Paulo para obtenção do título de Doutor em Ciências

Data:

\section{Banca Examinadora}

Prof. Dr.: Instituição:

Assinatura: Julgamento:

Prof. Dr.:

Instituição:

Assinatura:

Julgamento:

Prof. Dr.:

Instituição:

Assinatura:

Julgamento:

Prof. Dr.:

Instituição:

Assinatura:

Julgamento:

Prof. Dr.:

Instituição:

Assinatura:

Julgamento: 
Esta pesquisa foi financiada pelo CONSELHO NACIONAL DE DESENVOLVIMENTO CIENTíFICO E TECNOLÓGICO - CNPq, sob processo n० 141995/2007-6. 
À minha mãe, Ednamar Zandoná, mãe zelosa e amorosa, presente em todos os momentos da minha vida, a quem tudo devo;

Ao meu pai, Silvio Machado, exemplo de dedicação profissional;

À minha avó paterna, Angelina Machado (in memorian), minha segunda mãe;

Aos meus avós maternos, Dóris e Edmar Zandoná (in memorian), exemplos de dedicação e amor à família, luta e vitória na vida. 


\section{AGRADECIMENTOS ESPECIAIS}

\section{Ao Prof. Dr. Pedro Primo Bombonato,}

Orientador, mestre, amigo e espelho. Ao depositar em mim toda a confiança necessária para que eu seguisse sempre em frente, encontrei em ti os alicerces necessários para pintar o teto da minha capela.

À Profa. Dra. Paula de Carvalho Papa,

Professora e pesquisadora exemplar, personificação do verdadeiro cientista. Sem a sua dedicação e o seu comprometimento, constantes em todas as fases deste trabalho, a concretização e o sucesso desta pesquisa não seriam possíveis. Obrigado por iluminar os caminhos provedores desta conquista. 
À minha noiva, Andressa lurck Zonato, por serenamente compreender os motivos da minha constante ausência, mas principalmente pelo seu amor, que tanto me fortalece e me motiva, especialmente por me fazer acreditar na realização dos meus sonhos. 
À minha irmã Luciana e meu afilhado Lucas, por fazerem parte do que dá sentido à minha vida.

\section{À Família Zonato,}

pelo carinho, acolhimento, apoio e incentivo. 


\section{AGRADECIMENTOS}

Ao Prof. Dr. Anibal de Sant'Anna Moretti, por gentilmente conceder as matrizes iniciais desta pesquisa, inseminá-las e disponibilizar todo o suporte necessário para os procedimentos de coleta das amostras. Sua colaboração foi essencial para a realização deste trabalho.

Ao Prof. Dr. Carlos Alberto Mandarim-de-Lacerda, pela receptividade em seu laboratório, bem como por toda a atenção e paciência dispensadas, mas principalmente pela oportunidade de experiência com a Estereologia e pela preciosa colaboração neste trabalho.

Ao Prof. Dr. José Roberto Kfoury Júnior, pelos ensinamentos, amizade e gentil disponibilização do seu laboratório, como também pelos valiosos apontamentos e sugestões na ocasião do Exame de Qualificação e em diversas outras ocasiões.

À Profa. Dra. Maria Angélica Miglino, pelos ensinamentos e oportunidade de ingresso no Programa de Pós-Graduação em Anatomia dos Animais Domésticos e Silvestres da FMVZ-USP.

Ao Prof. Dr. Francisco Javier Hernandez Blazquez, pelos ensinamentos e pela sempre cordial concessão de materiais de seu laboratório quando eventualmente precisei.

Ao Prof. Dr. Hildebrando Gomes Benedicto, pela amizade e apoio no decorrer desse trabalho, como também pelos valiosos apontamentos e sugestões na ocasião do Exame de Qualificação. Especiais foram os dias de acolhida em sua casa, quando do meu primeiro contato pessoal com o Prof. Dr. Carlos Alberto Mandarim-deLacerda, no Rio de Janeiro;

À Profa. Dra. Telma Zorn, pelas preciosas elucidações histológicas e imunohistoquímicas, assim como pelo auxílio na escolha do anticorpo anti-laminina para imunomarcação dos vasos a serem quantificados neste estudo.

Ao Prof. Dr. Ruy Gastaldoni Jaeger, pela concessão da alíquota de anticorpo antilaminina que foi testada no material desta pesquisa.

À Profa. Dra. Tatiana Carlesso, pela amizade e auxílio com os primers.

A todos os professores de Pós-Graduação, pelo profissionalismo e pelo conhecimento compartilhado. 
À equipe do Laboratório de Pesquisa em Suínos da FMVZ-USP-Pirassununga, especialmente ao pós-graduando Felipe Horta, por toda a atenção e auxílio que dispensou à nossa equipe durante as coletas dos fetos.

Aos funcionários do abatedouro-escola da FMVZ-USP-Pirassununga, pela cooperação e paciência durante os procedimentos de coleta das amostras.

A Marina Moreira, Patricia Rossi Moriconi, Samia de Oliveira e Ana Caroline Ericeira, pelo especial auxílio nos procedimentos de coletas.

À empresa PenArLan Brasil Ltda., na pessoa da Sra. Sandrine Dufeu, gerente da Granja Semesa e do Sr. Gabriel Moreira Salum, médico veterinário do Departamento Técnico, pela disposição em conceder informações pertinentes aos animais empregados neste experimento, bem como aos locais e datas de abate de leitões e fêmeas de descarte.

Ao frigorífico Frigogil, na pessoa do Sr. Gilmar, e a todos os funcionários da empresa, pela especial atenção dispensada à nossa equipe durante os trabalhos de coleta.

Aos motoristas da FMVZ-USP, pela dedicação e suporte durante as viagens para coleta.

Aos queridos amigos do Laboratório para Estudos Morfofuncionais e Endocrinologia (LEME), pós-graduandos e alunos de iniciação científica, pelo companheirismo e extraordinária cooperação durante todos esses anos de intensas atividades laboratoriais, coletas e atividades acadêmicas. Não me vejo capaz de listar a contribuição de cada um nesta pesquisa, pois mais do que agradecimentos a auxílios práticos e técnicos, considero que devo-lhes agradecer a sua participação na minha formação científica. À Liza Margareth Medeiros de Carvalho Souza, Luciana Alves de Fátima, Mariana Nunes La Paz, Alex Sander Dias Machado, Joana Mona e Pinto, Nathia Nathaly Rigoglio, Laura Pacheco Artoni e Adriano Savoia Morales.

Aos professores, alunos e funcionários do Laboratório de Morfologia e Morfometria Cardivascular (LMMC) da Universidade Estadual do Rio de Janeiro (UERJ), pela receptividade, acolhimento e toda atenção a mim dispensada durante os trabalhos de quantificação vascular, especialmente à Profa. Dra. Marcia Barbosa Aguila, aos pós-graduandos Geraldo Silva-Júnior e Thiago da Silva Torres, pelas pacientes explicações e orientações técnicas, teóricas e práticas, como também a Milton Vieira Costa, Júlio César Fraulob Aquino, Isabele Bringhenti Sarmento, Mariana CattaPreta, Sandra Barbosa da Silva, Nayara Peixoto Silva, Alini Schultz Moreira, Leonardo de Souza Mendonça, Fernanda Amorim M. Nascimento, Caroline Fernandes-Santos, Vanessa de Souza Mello, Bianca Martins Gregório, Ana Maria J. 
Volpato, Eliete Dalla Corte Frantz, António ludgero C. Jr, Alessandra da Rocha Pinheiro, Tatiane da Silva Faria, Thatiany Marinho e Marcela Anjos Martins.

Às amigas Fernanda Rodrigues Agreste e Camila Ercolini Barroso, minhas "amigas do timo", pelo agradável convívio e companheirismo de todos esses anos, como também pelo compartilhamento de conhecimentos e experiências técnico-científicas, sobretudo, pela amizade.

Aos amigos pós-graduandos, pelos momentos de descontração e pelos momentos de seriedade, pelas alegrias compartilhadas e pelas tristezas consoladas, enfim, pela prazerosa convivência e sincera amizade, em especial à: Carlo Magenta Cunha, Marcelo Mendes Alves, Matheus Tajra Feitosa, Evander Bueno, Thiago Aloia, Carlos Alberto Sarmento, Caio Biasi, Marina Moreira, Simone Machado Pereira, Renato e Alida Gerger, Leandro Fadel, Guilherme Burzon, Miryan Alva, Juliana Passos, Juliana Plácido Guimarães, Ana Paula Silva, Elizângela dos Anjos Silva, Claudia Kanashiro, Fabiana Matsumoto, Rafael Agopian, Miller Rodrigo Pereira, Yuri Karacas, Maria Monteiro de Araújo, Fernando Garbelotti, Carlos Eduardo Cruz, Flavio Ribeiro, Karla Patrícia, Cristiane Wenceslau, Marina Pandolphi Brolio, André Franciolli, Gerlane de Medeiros, Dulcinéa Gonçalves Teixeira, Marina Brito, Angélica Oliveira, Alvaro Galdos, Maria Cecília, Cristiane Macedo Del Rio do Vale, Lilian Kamikawa, Adriana Morini, João Carlos Morini Jr., Gisele Saviani, Josy Alvarenga Cal, Andrea Bogoslavski, Fernando Ladd, André Gati, Alexandro Rodrigues, Regina Bolina, Linda e Victor Hugo Vieira.

Ao amigo Edinaldo Ribas Farias, técnico do Laboratório de Anatomia Macroscópica (LAM), que logo nos primeiros dias de convívio se mostrou um camarada e tanto. Obrigado por toda a dedicação, prontidão, auxílio, paciência e confiança durante todos esses anos em que precisei, usei e abusei do LAM e dos seus serviços.

Ao amigo Ronaldo Agostinho da Silva, técnico do Laboratório de Histologia e Embriologia, por toda a dedicação, atenção, auxílio e confiança durante as muitas horas de trabalho no laboratório, sempre menos penosas devido às prazerosas prosas e cômicos acontecimentos.

Aos amigos João do Carmo Freitas e Raimundo Leal de Sousa, técnicos do Museu de Anatomia Veterinária (MAV) Prof. Dr. Plínio Pinto e Silva, por toda a atenção, dedicação, prontidão e auxílio nas atividades curriculares e extra-curriculares, como também pelas valiosas trocas de experiências técnico-anatômicas. Sua receptividade no dia do meu primeiro contato com o Setor de Anatomia dos Animais Domésticos e Silvestres, quando cheguei muito cedo pela manhã e a única porta aberta que encontrei foi a do MAV, me assegurou que ali eu acabara de conhecer pessoas formidáveis, apaixonadas pelo que fazem e que me proporcionariam momentos especiais durante os anos que viriam. 
Às amigas Sandra e Maíse, técnicas do Laboratório de Microscopia Eletrônica, por todo o suporte e apoio.

Ao amigo, Diogo Palermo Neto, técnico do Laboratório de Anatomia Microscópica e Imuno-histoquímica, pelo sempre prestativo auxílio nos momentos de necessidade, pelos grandes momentos de descontração extra-laboratoriais e pelos sempre empolgantes debates musicais.

À Sra. Fátima de Lourdes Minari, secretária do MAV, por toda a dedicação e suporte.

Aos amigos Jaqueline Martins de Santana e Maicon Silva, secretários do Setor de Anatomia dos Animais Domésticos e Silvestres da FMVZ-USP, por toda a prestatividade e paciência que dispuseram durante esses anos que tiveram seus serviços intensamente por mim requisitados.

Aos funcionários da Biblioteca Virginie Buff D'Ápice, pela prestatividade, profissionalismo, paciência e amizade, especialmente à Helena, Fernanda Cezar, Elza Faquim e Solange A. Santana.

Aos funcionários da secretaria de Pós-Graduação da FMVZ-USP, Joana Ferreira Dias de Vasconcelos, Carlos Alberto da Silva Vasconcelos, Dayse Maria Alves Flexa, especialmente à Cláudia Lima, pela enorme paciência e amizade.

Ao amigo Dermeval Garcia Costa Junior, pela convivência, apoio e incentivo.

À amiga Profa. Dra. Elizabeth Moreira dos Santos Schmidt, pessoa de fundamental importância na minha vida científica e particular, profissional dedicada e exemplar, amiga incondicional.

Ao amigo Prof. Dr. Fabiano Montiani-Ferreira, pelas inspirações científicas e realizações profissionais, como também pelo apoio e incentivo durante todos esses anos. Agradeço-Ihe, ainda, toda sua paciência e compreensão, quando por muitas vezes precisei deixar um pouco de lado nossos trabalhos.

Aos amigos Prof. Dr. Rogério Ribas Lange e Prof. Dr. Ricardo Guilherme D’Otaviano de Castro Vilani, pelo exemplo, apoio e incentivo.

Ao amigo Prof. Dr. Gilberto Valente Machado, exemplo de dedicação à docência e à ciência anatômica, o maior entusiasta na anatomia veterinária que já conheci, pessoa em quem encontrei motivações a mais para continuar entusiasmado pela anatomia e pela sacrificante, mas prazerosa e recompensadora, tarefa de aprender, aprimorar e divulgar o conhecimento; obrigado, meu guru, pelo exemplo, amizade, incentivo e apoio. 
À Universidade do Contestado (UnC), na pessoa dos professores Dr. Argus Gumbowski, Dr. Luiz Mário Fedalto, Hamilton Wendt, Simone Wendt e Dra. Daniela Pedrassani. Seu suporte, incentivo e cooperação foram fundamentais neste processo de doutoramento.

Aos estimados professores, colegas de trabalho na UnC, Luimar Carlos Kavinski, Luiz Alberto Rincoski Faria, Waldir Hamann, Celso Pilati, Dodani Celino Machado, Joanele Lourence Corato, Osdival Pacheco, Paulo Roberto Barreto Piekarski, Ronaldo Flemming, Rui Branco, Simone Machado Pereira, Tânia Dello Monaco Martins Bona, Priscilla Ricabone Muradas e José Francisco Ghignatti Warth.

À Profa. Dra. Itaíra Susko, pelo apoio e pelas sempre sábias palavras de conforto e incentivo.

Ao Prof. Dr. João Caetano Fortes, pela amizade, apoio e enorme incentivo.

A todos os funcionários da UnC, pelo suporte e incentivo, especialmente a Solange, Luci Sardá, Gabriela Soares, Elaine Cristina Scheuer, Juliana A. Becker, Jeverson Cechinel da Silva, Dário, Milton Finta, Edinho e Fernando Kutelak.

Aos animais que involuntariamente doaram seus corpos para a realização desta pesquisa, minha eterna dívida, também em nome dos seres que um dia possam vir a ser beneficiados com a sua contribuição.

Por fim, àqueles que por meio da música embalaram, impulsionaram, animaram e reanimaram o meu doutoramento durante todos esses anos de pesquisa; sem 0 trabalho dessas pessoas, certamente o meu seria muito mais difícil. Portanto, meus agradecimentos a estes senhores e seus parceiros, especialmente a Steve Harris \& Iron Maiden, Lemmy Kilmister \& Mortörhead, Angus e Malcon Young \& AC/DC, Joey Ramone (in memorian) \& The RAMONES, Eddie Spaghetti \& Supersuckers, Eddie Vedder \& Pearl Jam, Blaime \& Nashville Pussy, Mike Ness \& Social Distortion, James Hetfield \& Metallica, Tommy Yommi \& Black Sabbath, Tom Araya \& Slayer, Blind Marky Felchtone \& ZEKE, Marcello Nova \& Camisa de Vênus e, finalmente, ao cunhado Fábio Pohlman \& Circo Voador, pela especial participação neste último ano. 


\section{RESUMO}

MACHADO, M. VEGF e vascularização ao longo do desenvolvimento e involução do timo em suínos. [VEGF and vascularization during thymus development and involution in pigs]. 2010. 146 f. Tese (Doutorado em Ciências) Faculdade de Medicina Veterinária e Zootecnia, Universidade de São Paulo, São Paulo, 2010.

O timo é um órgão essencial para a maturação, diferenciação e seleção de linfócitos $\mathrm{T}$, consequentemente fundamental para 0 desenvolvimento da imunidade do organismo. Além do papel na manutenção da integridade tecidual, os vasos sanguíneos tímicos desempenham função no processo de migração de células precursoras de linfócitos para o interior do órgão. Sua arquitetura típica é caracterizada por grandes vasos localizados na junção corticomedular e uma fina cadeia de ramificações e anastomoses no interior do córtex, porém são pouco conhecidas as bases moleculares que induzem a formação desta particular vascularização, bem como os exatos mecanismos que desencadeiam a involução do órgão, evento relacionado a alterações nos padrões vasculares. Entretanto, tem sido demonstrado que as interações entre o estroma, que inclui o endotélio vascular, e o compartimento hematopoiético tímico desempenham papéis cruciais na funcionalidade do órgão. Sendo o VEGF um fator angiogênico essencial na formação do leito vascular tecidual e na modulação de funções diretamente relacionadas à vascularização, objetivamos neste estudo avaliar a expressão gênica e protéica deste fator de crescimento durante estágios de desenvolvimento e involução do órgão. Foram utilizadas amostras de timo suíno em 3 diferentes estágios de desenvolvimento fetal (65, 85 e 111 dias) e 2 estágios de vida pós-natal, um compreendendo fase de maturação (5 meses) e outro de involução do órgão (2 anos), compreendendo um total de 25 animais, divididos em 5 grupos $(n=5)$. A análise da expressão relativa do mRNA do sistema VEGF-A, acessada por meio de PCR em tempo real, apresentou modificações tempo-dependentes significativas $(P<0,05)$ em relação ao controle endógeno GAPDH. Também foram observadas diferenças significativas $(P \leq 0,05)$ na quantificação vascular por meio de estereologia entre as idades. A imunolocalização da proteína do VEGF e de seus receptores Flt-1 e KDR foi identificada no timo de todos os grupos experimentais e variou entre os grupos pré e pós-natais, com expressão mais rara nestes últimos, o que sugere diferenças temporais na modulação do mRNA no órgão. Assim como as células endoteliais, as células epiteliais tímicas demonstraram modulação pelo sistema VEGF-A, indicando ação parácrina e/ou autócrina deste fator de crescimento no timo. Os valores das variáveis estereológicas $S_{v[m]}$ e $V_{v[m]}$ do timo fetal em período próximo ao nascimento mantiveram-se maiores do que no córtex e se correlacionaram positivamente com a expressão do mRNA do KDR e negativamente 
com a do Flt-1 até a idade adulta. Ao contrário da expressão protéica, a expressão gênica do sistema VEGF-A pode se correlacionar negativamente com aspectos quantitativos da vascularização do timo pós-natal, como observado para o mRNA do VEGF e seu receptor Flt-1 a partir dos 5 meses de idade, quando os valores das variáveis $V_{v[v a s o s, t i m o]}, S_{v[v a s o s, t i m o]}$ e $L_{v[\text { vasos,timo] }}$ diminuíram significativamente $(P \leq 0,05)$, o que sugere uma resposta de compensação ou manutenção de uma condição hipóxica instalada no órgão.

Palavras-chave: Timo. Vascularização. VEGF. Desenvolvimento. Involução. 
ABSTRACT

MACHADO, M. VEGF and vascularization during thymus development and involution in pigs. [VEGF e vascularização ao longo do desenvolvimento e involução do timo em suínos]. 2010. 146 f. Tese (Doutorado em Ciências) Faculdade de Medicina Veterinária e Zootecnia, Universidade de São Paulo, São Paulo, 2010.

Crucial for maturation, differentiation and selection of $\mathrm{T}$ lymphocytes, the thymus is an essential organ to the development of immunity. In addition to its role in the maintenance of tissue integrity, thymus blood vessels play a role in migration of T-cell precursors into the organ, and show a typical architecture characterized by the presence of large blood vessels at the corticomedullary junction and fine network of branching vessels and anastomosing arcades extending into the cortex. The molecular basis of this typical vasculature and the exact mechanisms that trigger thymus involution are both not well understood. However, it has been shown that the interactions between thymus stroma, including vascular endothelium and the hematopoietic compartment play crucial roles for normal organ function. Thus, because VEGF is an essential angiogenic factor for induction of the vascular bed and modulation of functions directly related with vascularization, the aim of this study was to assess the temporal protein and mRNA expression of VEGF and its receptors Flt-1 and KDR in the thymus during early stages of its development and involution. Samples of thymus from 3 different stages of fetal development $(65,85$, and 111 days) and 2 stages of postnatal life of pigs, including one stage of maturation (5 months) and another of involution (2 years) comprising a total of 25 animals that were divided into 5 groups $(n=5)$. Relative mRNA expression of VEGF-A system, accessed by real-time $P C R$, showed temporal significant changes $(P<0.05)$ compared to endogenous control GAPDH. Quantification of blood vessels by means of stereology also showed significant differences $(P \leq 0.05)$ between ages. Positive immunostaining for VEGF and its receptors Flt-1 and KDR was identified in the thymus of all groups and it varied between the pre and postnatal groups with rare expression in the latter, suggesting temporal differences in the modulation of mRNA. Endothelial and epithelial cells showed modulation by the VEGF-A system, suggesting paracrine or alternatively autocrine activity of this growth factor. The values of the stereological parameters $S_{v[m]}$ and $V_{v[m]}$ of the thymus in fetal period around the birth remained higher than in the cortex and upregulated with mRNA expression of KDR and downregulated with mRNA expression of Flt-1 until adulthood. Unlike protein expression, gene expression gene expression of VEGF-A system can be downregulated with quantitative aspects of the postnatal thymus vascularization as observed for the mRNA of VEGF and its receptor Flt-1 from the

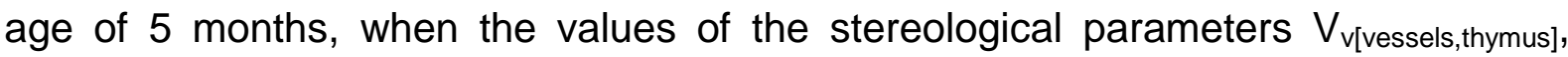


$\mathrm{S}_{\mathrm{v} \text { [vessels,thymus] }}$ and $\mathrm{L}_{\mathrm{v} \text { [vessels,thymus] }}$ decreased significantly $(\mathrm{P} \leq 0.05)$, which suggests a compensatory or maintenance response to an hypoxic condition in the organ.

Key words: Thymus. Vascularization. VEGF. Development. Involution. 


\section{LISTA DE ABREVIATURAS E SIGLAS}

3D

AF

ANOVA análise de variância

APTES 3-aminopropil-trietoxy-silano

CD

cDNA

CE

CET

CETc

CETm

$\mathrm{cm}^{3}$

$\mathrm{CN}$

$\mathrm{Ct}$

CT

DAB

DEPC

DN

DNase

dNTP

DP

DTT

Flt-1

três dimensões

arco faríngeo

grupo de diferenciação

célula endotelial

célula epitelial tímica

centímetro cúbico

crista neural

ciclo de amplificação

corpúsculo tímico

diaminobenzidina

dietil pirocarbonato

duplo negativo

desoxirribonuclease

duplo positivo

ditiotreitol ácido desoxirribonucléico complementar

célula (s) epitelial (ais) tímica (s) do córtex

célula (s) epitelial (ais) tímica (s) da medula

desoxirribonucleotídeo fosfatado

receptor 1 de tirosina-quinase semelhante a fms (peptídeo deformilase) 


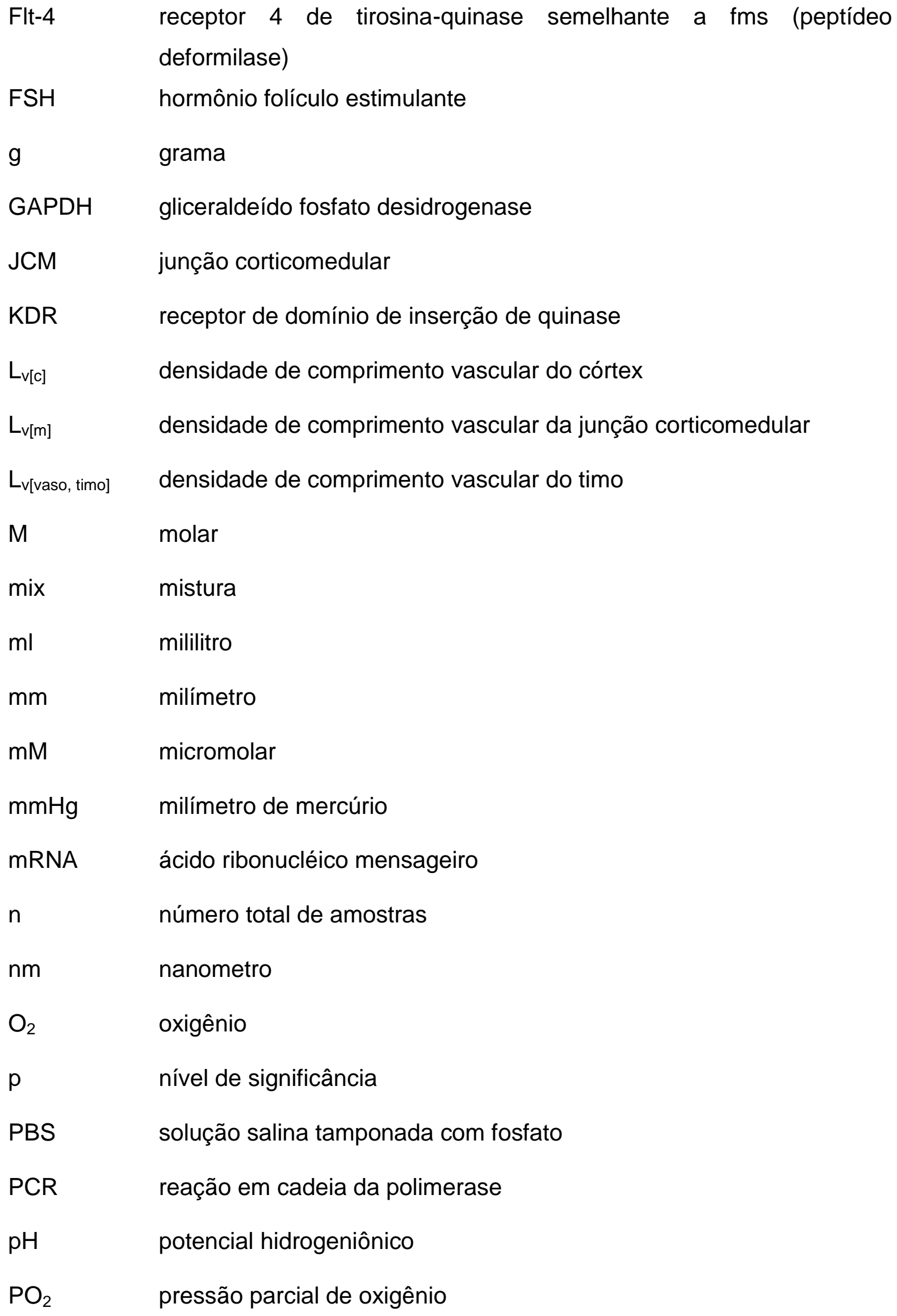


RANKL ligante do ativador do receptor do fator nuclear kbeta

RS região subcapsular

RN rendimento nápole

RNase ribonuclease

RT transcrição reversa

SAS sistema de análise estatística

$\mathrm{S}_{\mathrm{v}[\mathrm{c}]} \quad$ densidade de área vascular do córtex

$\mathrm{S}_{\mathrm{v}[\mathrm{m}]} \quad$ densidade de área vascular da junção corticomedular

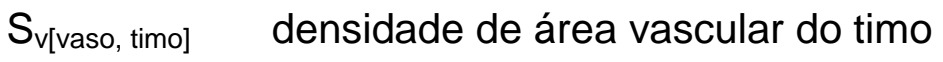

TBF terceira bolsa faríngea

$\mu \mathrm{g} \quad$ micrograma

$\mu \mathrm{l} \quad$ microlitro

UNG uracil glicosilase

VEGF fator de crescimento endotelial vascular

VEGFR-1 receptor 1 do fator de crescimento endotelial vascular

VEGFR-2 receptor 2 do fator de crescimento endotelial vascular

VEGFR-3 receptor 3 do fator de crescimento endotelial vascular

VPF fator de permeabilidade vascular

$\mathrm{V}_{\mathrm{v}[\mathrm{c}]} \quad$ densidade de volume vascular do córtex

$V_{v[m]} \quad$ densidade de volume vascular da junção corticomedular

$\mathrm{V}_{\mathrm{v}[\text { vaso, timo] }}$ densidade de volume vascular do timo 


\section{LISTA DE SÍMBOLOS}

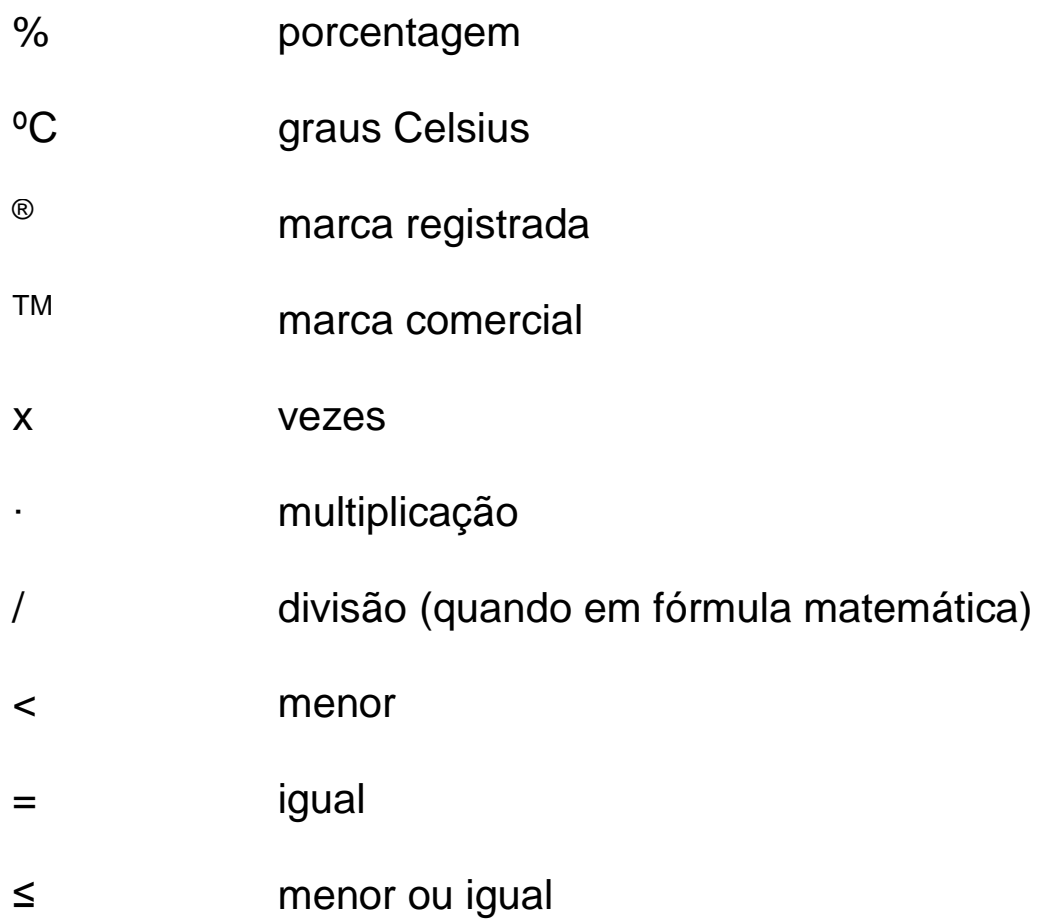




\section{LISTA DE FIGURAS}

Figura 1 - Timo de feto suíno com 65 dias de idade gestacional.........................42

Figura 2 - Representação esquemática do conceito de planos e cortes verticais.

Figura 3 - Representação esquemática da sequência de processamento de material para obtenção de cortes verticais.

Figura 4 - Sistema-teste utilizado para a quantificação vascular do timo de suínos em idades pré e pós-natais.

Figura 5 - Fotomicrografias da junção corticomedular (ם) e região profunda do córtex $(\square)$ do timo de suínos.

Figura 6 - Fotomicrografias da expressão da proteína VEGF no timo suíno. Reação imuno-histoquímica realizada com anticorpo policlonal antiVEGF (Santa Cruz sc 152) diluído 1:300. Amostras dos grupos prénatais: 65 (A e B), 85 (C e D) e 111 (E e F) dias de gestação.

Figura 7 - Fotomicrografias da expressão da proteína VEGF no timo suíno. Reação imuno-histoquímica realizada com anticorpo policlonal antiVEGF (Santa Cruz sc 152) diluído 1:300. Amostras dos grupos pós-natais: 5 meses (A e B) e 2 anos de idade (C e D).

Figura 8 - Fotomicrografias da expressão da proteína VEGF no timo suíno. Reação imuno-histoquímica realizada com anticorpo policlonal antiVEGF (Santa Cruz sc 152) diluído 1:300. A) Região interlobular de um feto de 85 dias. B) Córtex (crt), medula (m) e junção corticomedular (jcm) de um feto de 111 dias. C) Ampliação da JCM de B. D) JCM de um animal de 5 meses de idade...

Figura 9 - Fotomicrografias da expressão da proteína Flt-1 no timo suíno. Reação imuno-histoquímica realizada com anticorpo policlonal antiFlt-1 (Santa Cruz sc 316) diluído 1:500. Amostras dos grupos prénatais: 65 (A e B), 85 (C e D) e 111 (E e F) dias de gestação..

Figura 10 - Fotomicrografias da expressão da proteína Flt-1 no timo suíno. Reação imuno-histoquímica realizada com anticorpo policlonal antiFlt-1 (Santa Cruz sc 316) diluído 1:500. Amostras dos grupos pósnatais: 5 meses (A e B) e 2 anos de idade (C e D)...

Figura 11 - Fotomicrografias da expressão da proteína Flt-1 no timo suíno. Reação imuno-histoquímica realizada com anticorpo policlonal antiFlt-1 (Santa Cruz sc 316) diluído 1:500. A) Região interlobular de um feto de 65 dias. B) Região interlobular de um animal de 5 meses. C) JCM de um feto de 111 dias. D) JCM de um animal de 2 anos de idade. 
Figura 12 - Fotomicrografias da expressão da proteína KDR no timo suíno. Reação imuno-histoquímica realizada com anticorpo policlonal antiKDR (Santa Cruz sc 315) diluído 1:500. Amostras dos grupos prénatais: 65 (A e B), 85 (C e D) e 111 (E e F) dias de gestação..

Figura 13 - Fotomicrografias da expressão da proteína KDR no timo suíno. Reação imuno-histoquímica realizada com anticorpo policlonal antiKDR (Santa Cruz sc 315) diluído 1:500. Amostras dos grupos pósnatais: 5 meses ( $\mathbf{A}$ e $\mathbf{B})$ e 2 anos de idade ( $\mathbf{C}$ e $\mathbf{D})$.

Figura 14 - Fotomicrografias da expressão da proteína KDR no timo suíno. Reação imuno-histoquímica realizada com anticorpo policlonal antiKDR (Santa Cruz sc 315) diluído 1:500. A) JCM de um feto de 85 dias. B) Região interlobular de um feto de 85 dias. C) JCM de um animal de 5 meses. D) Córtex de um animal de 5 meses 


\section{LISTA DE GRÁFICOS}

Gráfico 1 - Densidade de volume vascular ( $\left.\mathrm{V}_{\mathrm{v}[\text { vasos,timo] }}\right)$ no córtex (C) e junção corticomedular $(\mathrm{M})$ do timo suíno nos grupos experimentais pré e pós-natais

Gráfico 2 - Densidade de superfície vascular ( $\left.S_{v[v a s o s, t i m o]}\right)$ no córtex (C) e junção corticomedular $(\mathrm{M})$ do timo suíno nos grupos experimentais pré e pós-natais.

Gráfico 3 - Densidade de superfície vascular $\left(S_{\text {v[vasos,timo] }}\right)$ no córtex (C) e junção corticomedular (M) do timo suíno nos grupos experimentais pré e pós-natais

Gráfico 4 - Expressão relativa do mRNA do VEGF (A), Flt-1 (B) e KDR (C) no timo suíno ao longo do seu desenvolvimento (65, 85 e 111 dias de gestação), maturação (5 meses de idade pós-natal) e em fase de involução (2 anos de idade).

Gráfico 5 - Relação entre a expressão gênica temporal do VEGF e seus receptores (Flt-1 e KDR) e a variável estereológica densidade de volume vascular no córtex $\left(\mathrm{V}_{\mathrm{v}[\mathrm{c}]}\right)$ e na medula $\left(\mathrm{V}_{\mathrm{v}[\mathrm{m}]}\right)$ do timo de suínos em idades pré-natais (65, 85 e 111 dias) e pós-natais de 5 meses (150 dias) e 2 anos (720 dias) de idade.

Gráfico 6 - Relação entre a expressão gênica temporal do VEGF e seus receptores (Flt-1 e KDR) e a variável estereológica densidade de área vascular no córtex $\left(\mathrm{S}_{\mathrm{v}[\mathrm{c}]}\right)$ e na medula $\left(\mathrm{S}_{\mathrm{v}[\mathrm{m}]}\right)$ do timo de suínos em idades pré-natais (65, 85 e 111 dias) e pós-natais de 5 meses (150 dias) e 2 anos (720 dias) de idade.

Gráfico 7 - Relação entre a expressão gênica temporal do VEGF e seus receptores (Flt-1 e KDR) e a variável estereológica densidade de comprimento vascular no córtex $\left(\mathrm{L}_{v[\mathrm{c}]}\right)$ e na medula $\left(\mathrm{L}_{\mathrm{v}[\mathrm{m}]}\right)$ do timo de suínos em idades pré-natais $(65,85$ e 111 dias) e pós-natais de 5 meses (150 dias) e 2 anos (720 dias) de idade 


\section{LISTA DE QUADROS}

Quadro 1 - Divisão dos grupos experimentais por idade e indicação do número de animais por grupo e sexo. 60

Quadro 2 - Primers para VEGF, Flt-1, KDR e GAPDH suíno para PCR em tempo real. 


\section{LISTA DE TABELAS}

Tabela 1 - Perfis por campo e valores das variáveis estereológicas calculados para o córtex e JCM do timo de cada animal do grupo I.

Tabela 2 - Perfis por campo e valores das variáveis estereológicas calculados para o córtex e JCM do timo de cada animal do grupo II.

Tabela 3 - Perfis por campo e valores das variáveis estereológicas calculados para o córtex e JCM do timo de cada animal do grupo III.

Tabela 4 - Perfis por campo e valores das variáveis estereológicas calculados para o córtex e JCM do timo de cada animal do grupo IV.

Tabela 5 - Perfis por campo e valores das variáveis estereológicas calculados para o córtex e JCM do timo de cada animal do grupo $\mathrm{V}$.

Tabela 6 - Valores de $p$ do pós-teste de Tukey para verificação das diferenças entre os valores das variáveis estereológicas estimadas no córtex dos timos de grupos suínos em idades pré e pós-natais.

Tabela 7 - Valores de $p$ do pós-teste de Tukey para verificação das diferenças entre os valores das variáveis estereológicas estimadas na JCM dos timos de grupos suínos em idades pré e pós-natais.

Tabela 8 - Valores de $\mathrm{p}$ do teste $t$ pareado para verificação das diferenças entre córtex e JCM dos timos de grupos suínos em idades pré e pós-natais.

Tabela 9 - Correlação entre as variáveis estereológicas e a expressão gênica do sistema VEGF-A 


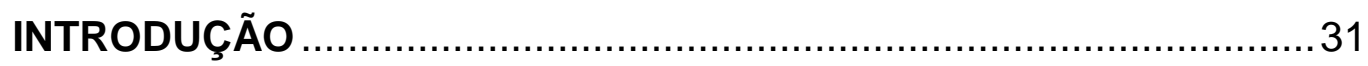

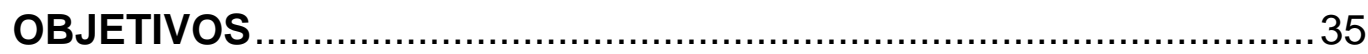

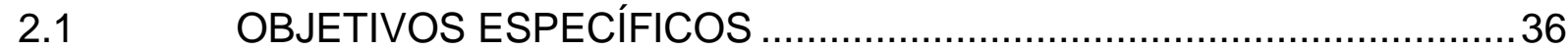

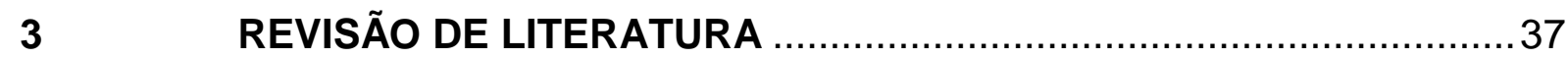

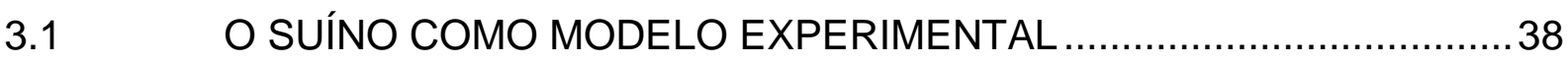

3.2 TOPOGRAFIA E ANATOMIA MACROSCÓPICA DO TIMO SUÍNO......39

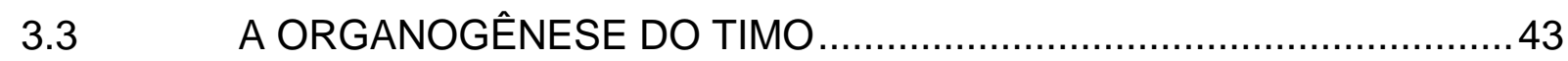

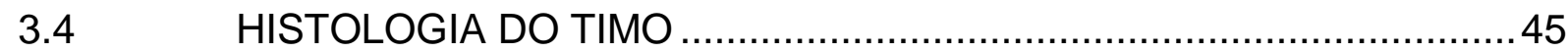

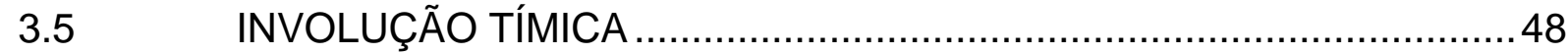

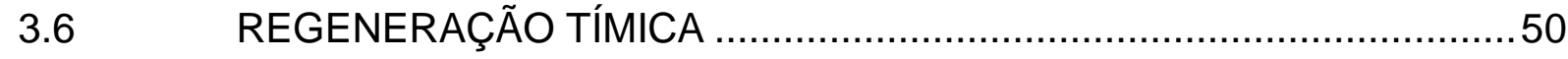

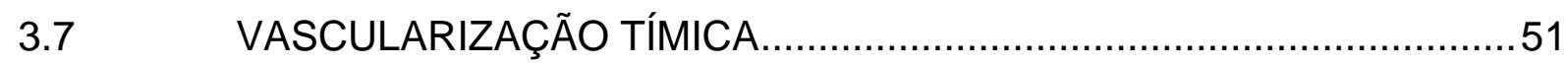

3.8 VASCULOGÊNESE E ANGIOGÊNESE. ..........................................

3.9 SISTEMA VEGF-A E SEUS RECEPTORES...................................53

3.9.1 As Interações Celulares e a Modulação do Ambiente Tímico

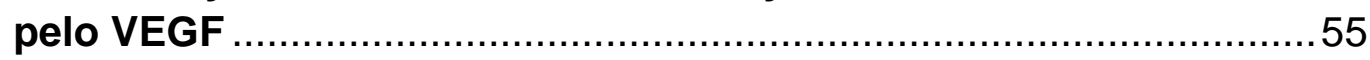

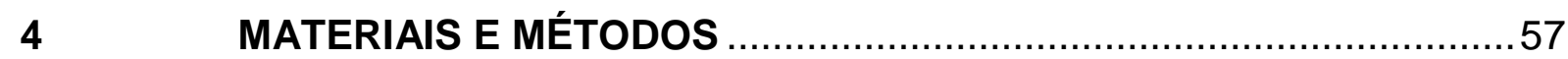

4.1 ORIGEM DAS AMOSTRAS E LOCAIS DO EXPERIMENTO.................58

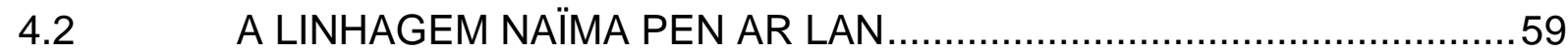

4.3 DEFINIÇÃO DOS GRUPOS EXPERIMENTAIS .................................59

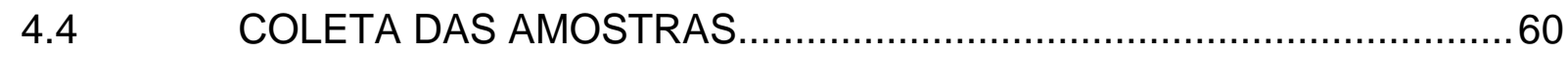

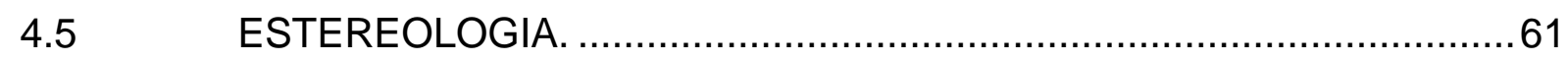

4.5.1 Processamento do Material para Estereologia ................................61

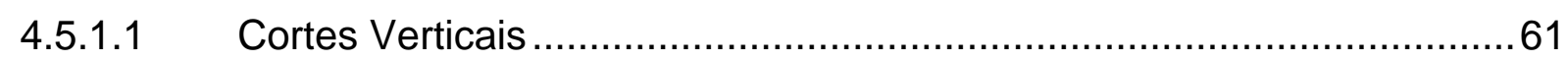

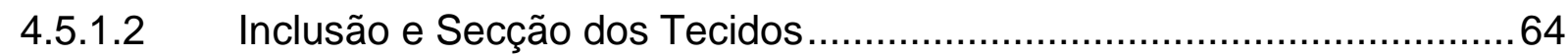

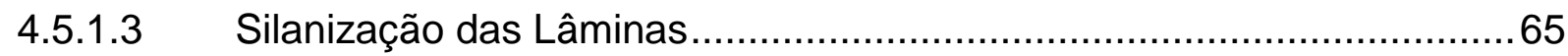

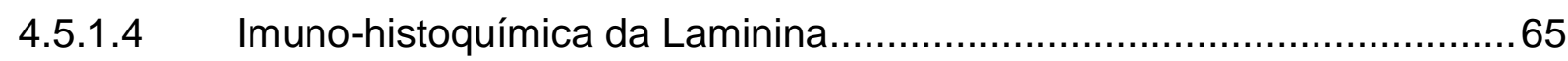

4.5.2 Sistemas-teste para a Quantificação Vascular .................................66

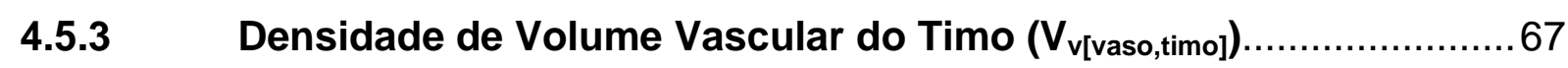

4.5.4 Densidade de Superfície Vascular do Timo $\left(\mathrm{S}_{\mathrm{v}[\mathrm{vaso}, \mathrm{timo}]}\right)$....................68

4.5.5 Densidade de Comprimento Vascular do Timo ( $\left.\mathrm{L}_{\mathrm{v}[\mathrm{vas}, \mathrm{timo}]}\right)$..............68

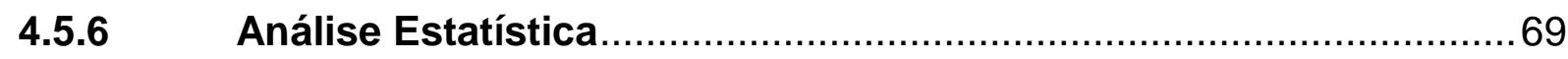


4.6 AVALIAÇÃO DA EXPRESSÃO DE mRNA 69

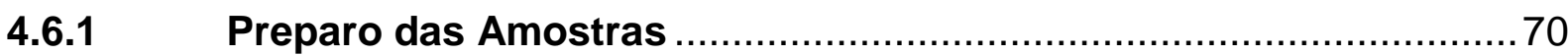

4.6.2 Acondicionamento das Amostras para Extração do RNA Total ......70

4.6.3 Extração de RNA Total pelo Método de Trizol .................................70

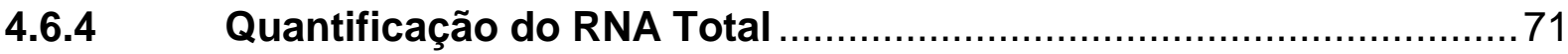

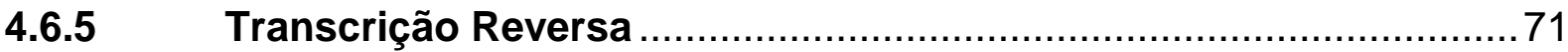

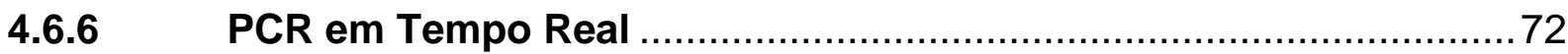

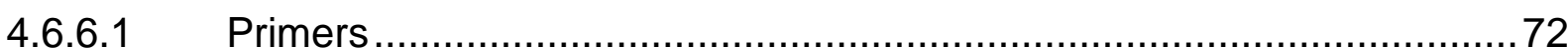

4.6.6.2 Condições da Reação de PCR em Tempo Real ..................................74

4.6.6.3 Determinação da Eficiência dos Primers.............................................76

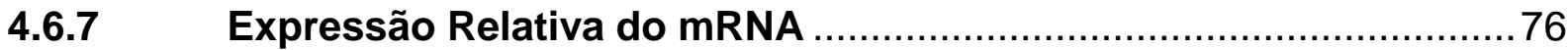

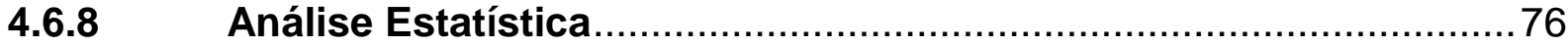

4.7 PROCESSAMENTO DO MATERIAL PARA IMUNOHISTOQUÍMICA DO VEGF E SEUS RECEPTORES (FIt-1 E KDR) .......77

4.7.1 Fixação, Inclusão e Secção dos Tecidos ………………………....77

4.7.2 Imuno-histoquímica do VEGF e seus Receptores (FIt-1 e KDR) ......78

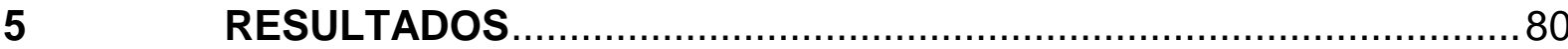

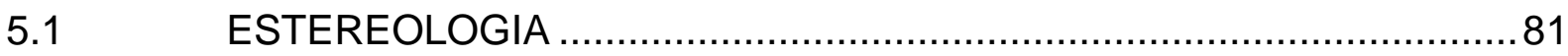

5.1.1 Densidade de Volume Vascular do Timo $\left(\mathrm{V}_{\mathrm{v}[\mathrm{vaso}, \mathrm{timo}]}\right) \ldots \ldots \ldots \ldots \ldots \ldots \ldots . . . . . . . . . . . .2$

5.1.2 Densidade de Superfície Vascular do Timo $\left(\mathrm{S}_{\mathrm{v}[\mathrm{vaso}, \mathrm{timo}]}\right)$..................84

5.1.3 Densidade de Comprimento Vascular do Timo ( $\left.\mathrm{L}_{\mathrm{v}[\mathrm{vas}, \mathrm{timo}]}\right)$............. 85

5.2 EXPRESSÃO RELATIVA DO mRNA DO VEGF E SEUS RECEPTORES (Flt-1 E KDR) .....................................................94

5.3 IMUNOLOCALIZAÇÃO DO VEGF E SEUS RECEPTORES (FIt-1 E

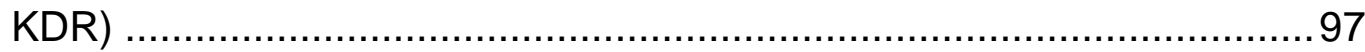

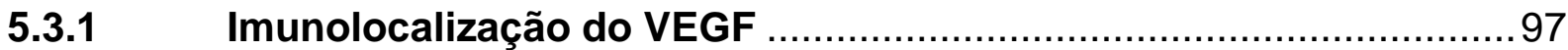

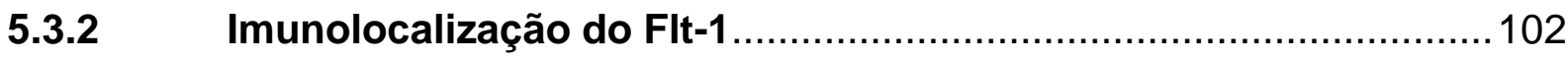

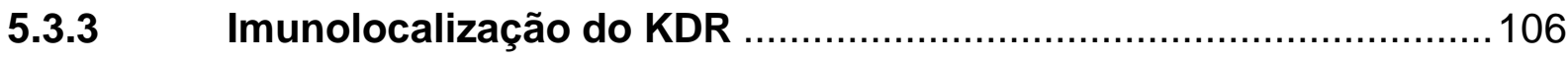

5.4 RELAÇÃO ENTRE A EXPRESSÃO GÊNICA TEMPORAL DO VEGF E SEUS RECEPTORES (Flt-1 E KDR) E AS VARIÁVEIS $V_{\text {vivaso,timo], }} S_{\text {vivaso,timo] }} E L_{\text {v[vaso,timo] }}$ NO CÓRTEX E JUNÇÃO CORTICOMEDULAR

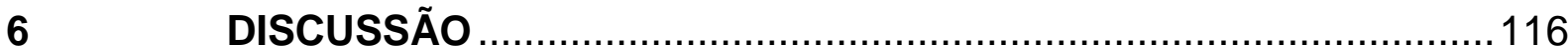

6.1 MORFOLOGIA DO TIMO SUÍNO …...............................................117 
6.2 AMOSTRAGEM EXPERIMENTAL ...............................................118

6.3 ASPECTOS HISTOLÓGICOS DO TIMO SUÍNO …...........................120

6.4 A EXPRESSÃO DO SISTEMA VEGF-A E A VASCULARIZAÇÃO

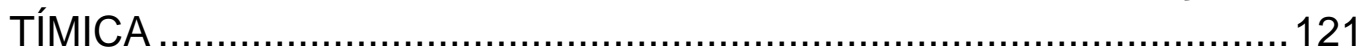

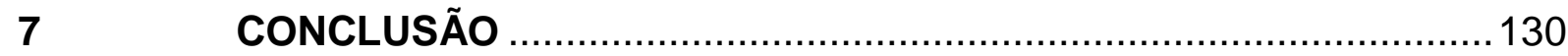

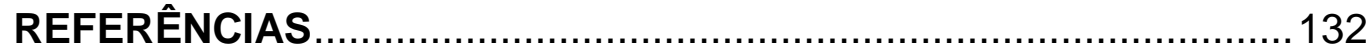


INTRODUÇÃO 


\section{INTRODUÇÃO}

Durante a vida fetal e no período neonatal o timo é o órgão que apresenta maior importância imunológica e, anatomicamente, é o maior órgão linfático com atividade linfopoiética (DRUMMOND, 1996). Além de precursor da linfopoiese, o timo também está intimamente relacionado ao sistema endócrino, principalmente à função gonadal (MIN et al., 2006). Diversos experimentos revelam que o desenvolvimento normal dos órgãos linfóides distribuídos pelo organismo, assim como a manutenção dessas estruturas é dependente do timo (APPOLINÁRIO, 1998).

Sabe-se que as respostas imunológicas, relacionadas de diferentes formas às estruturas do sistema linfático, muitas vezes são intermediadas e coordenadas pelo timo. Apesar de responsabilizada por mecanismos fundamentais na aquisição das defesas e consequentes respostas orgânicas, a função tímica ainda não é totalmente esclarecida, tampouco as bases morfológicas que respondem por tal função (BOMBONATO, 1997).

Sabe-se que a partir da puberdade o timo inicia um processo de involução e que as primeiras modificações nos compartimentos do órgão se iniciam em proximidade direta com os vasos sanguíneos (BRELINSKA et al., 2008). Neste contexto, um estudo quantitativo da vascularização tímica constitui ferramenta importante para o entendimento do comportamento vascular no órgão durante estágios de desenvolvimento e involução, já que questões que aparecem frequentemente em períodos de adaptação, evolução ou doenças no organismo, necessitam de análises quantitativas para seu melhor entendimento (ANDERSEN; PAKKENBERG, 2003). Além disso, os vasos sanguíneos do timo apresentam uma arquitetura típica, caracterizada por grandes vasos localizados na junção corticomedular e uma fina cadeia de ramificações e anastomoses no interior do córtex (ANDERSON et al., 2000), sendo pouco conhecidas as bases moleculares que induzem a formação desta típica vascularização tímica (MÜLLER et al., 2005).

O estudo da vascularização do timo nas diferentes espécies, principalmente naquelas de interesse econômico e nas que podem ser utilizadas como modelo 
experimental é de real necessidade, já que irrigação e drenagem sanguíneas são elementos importantes na funcionalidade e na preservação tecidual de qualquer órgão.

A alta morbidade e mortalidade das doenças neonatais representam sérios problemas para a economia pecuária. Dessa forma, também a caracterização dos processos de formação, manutenção e involução dos órgãos é fundamental para a compreensão de como o sistema imune se desenvolve, quais mecanismos estão prontos para proteger o neonato quando da primeira invasão microbiana e o que pode ser feito para aumentar a resistência neonatal a patógenos (SINKORA et al., 2002). Sendo o timo modulador da atividade dos demais órgãos linfóides, o conhecimento dos mecanismos que desencadeiam o seu desenvolvimento, maturação e involução, é imprescindível para o entendimento da atividade de todo o sistema linfóide.

Fatores angiogênicos como o fator de crescimento endotelial vascular (VEGF) são essenciais para a formação do leito vascular tecidual (PLENDL, 2000) e para a modulação de funções não diretamente relacionadas à vascularização como migração e proliferação celular (YOSHIDA et al., 1996), produção hormonal (YAMASHITA et al., 2008) e, ainda, a mais recente função atribuída a este fator de crescimento, a imunomodulação (KISELEVA et al., 2005), que torna o conhecimento de sua expressão no timo um passo fundamental em direção ao entendimento das interações célula-célula no órgão.

A grande importância da espécie suína na economia pecuária e mesmo como modelo experimental, inclusive especificamente para estudos imunológicos (ROTHKÖTER; SOWA; PABST, 2002), nos leva a buscar maior compreensão sobre o desenvolvimento e manutenção da imunidade nesta espécie.

O conhecimento adquirido em um estudo temporal que abrange fases críticas do desenvolvimento tímico, desde a fase fetal até a idade adulta, passando pela puberdade, pode fornecer dados valiosos para o melhor entendimento da morfofisiologia do órgão. O resultando desse entendimento não apenas pode refletir no aperfeiçoamento dos protocolos de imunização já existentes, o que atualmente tem recebido especial atenção devido à ameaça do surgimento de novas doenças 
entre as espécies domésticas de produção, inclusive doenças potencialmente zoonóticas (FRASER et al., 2009; MEHLE; DOUDNA, 2009), mas principalmente na compreensão dos mecanismos de manutenção e aprimoramento da imunidade.

Frente ao exposto, pretendemos neste experimento testar a hipótese de que o padrão de expressão do sistema VEGF-A acompanha o desenvolvimento e a involução do timo e está diretamente relacionado à vascularização do órgão. 
OBJETIVOS 


\section{OBJETIVOS}

Este estudo objetivou comparar a expressão temporal do sistema VEGF-A entre amostras de timo suíno em três diferentes estágios de desenvolvimento fetal e dois estágios de vida pós-natal, um compreendendo fase de maturação e outro de involução do órgão, além de estabelecer relações destas expressões com a vascularização do timo nos diferentes grupos estudados.

\subsection{OBJETIVOS ESPECÍFICOS}

a) Estudar no órgão a expressão temporal gênica e protéica do VEGF e seus receptores VEGFR-1 (Flt-1) e VEGFR-2 (KDR).

b) Estimar a densidade de volume vascular.

c) Estimar a densidade de superfície vascular.

d) Estimar a densidade de comprimento vascular.

e) Estudar a relação entre as variáveis estereológicas e a expressão gênica e protéica do VEGF e seus receptores VEGFR-1 (Flt-1) e VEGFR-2 (KDR), nas diferentes idades pré e pós-natais. 
REVISÃO DE LITERATURA 


\section{REVISÃO DE LITERATURA}

Informações referentes à espécie animal utilizada como modelo experimental no presente estudo, bem como assuntos pertinentes ao entendimento da abordagem dada ao órgão alvo desta pesquisa, estão inseridos nas seções que seguem deste capítulo.

\subsection{O SUÍNO COMO MODELO EXPERIMENTAL}

Pesquisas clínicas e pré-clínicas que visam o aumento da qualidade de vida da espécie humana são realizadas em diversas espécies de animais vertebrados e invertebrados (MARIANO, 2003). O rato e o camundongo, modelos experimentais mais frequentemente utilizados, apresentam algumas vantagens, mas também diversas desvantagens, dentre as quais as mais relevantes são o período curto de gestação e a distância filogenética para com a espécie humana, determinante de diferenças metabólicas relevantes (HEIN; GRIEBEL, 2003; MESTAS; HUGHES, 2004). Neste contexto, a espécie suína (Sus scropha domestica) é muito mais conveniente, pois além de ser de fácil aquisição, apresenta baixa relação custobenefício e interesse agropecuário economicamente importante (SINKORA et al., 2002). Além disso, por diversas semelhanças morfofuncionais e patológicas com o homem, é considerada uma espécie apropriada à pesquisa biomédica (MARIANO, 2003). Tais semelhanças são amplamente documentadas e, dentre as principais, se destacam aspectos ligados à odontologia, nefrologia, oftalmologia, dermatologia, cardiologia, gastroenterologia e imunologia (BUSTARD; MCCLELLAN, 1965). Tumbleson (1986), ainda comenta semelhanças específicas na vascularização pulmonar, distribuição da artéria coronária, propensão para obesidade, taxa respiratória e comportamento social.

Um ponto favorável da utilização da espécie em estudos imunológicos é o conhecido período gestacional que dura, em média, 3 meses, 3 semanas e 3 dias, perfazendo um total médio de 114 dias. Tal período, relativamente prolongado, 
permite fácil extrapolação para o período gestacional humano, proporcionando a conveniente oportunidade de estudar o desenvolvimento do sistema imune dentro de estágios bem caracterizados (SINKORA et al., 2002; SINKORA et al., 2005). Além disso, os fetos suínos são livres de influências regulatórias maternas devido a uma placenta epiteliocorial. Este tipo de placenta previne a transferência de altos níveis maternais de imunoglobulinas, o que proporciona que esses fetos e leitões livres de germes sejam especialmente úteis para estudos imunológicos, permitindo a distinção entre fatores imunológicos intrínsecos que se desenvolvem espontaneamente daqueles que surgem sob influência da imunidade passiva, fatores maternos e estímulos antigênicos externos (SINKORA et al., 2005).

Acasalamentos programados, alta fecundidade, proporções fetais e a disponibilidade de um amplo painel de imunoreagentes e primers específicos complementam as vantagens deste modelo experimental (SINKORA et al., 2002).

\subsection{TOPOGRAFIA E ANATOMIA MACROSCÓPICA DO TIMO SUÍNO}

Dentre os animais domésticos, o timo é um órgão que se apresenta macroscopicamente de forma muito variável de acordo com a espécie. De acordo com Schummer et al. (1981), em alguns mamíferos como o homem, equino, canino e felino, apenas a parte torácica do órgão é desenvolvida, enquanto que a parte cervical está presente e é proeminente em ruminantes e suínos; nas espécies equina e felina, apenas eventualmente é observado um sugestivo indício dessa parte. Os mesmos autores ainda comentam que nos animais que apresentam ambas as partes (cervical e torácica), estas são contínuas por meio de um estreito istmo localizado na entrada do tórax. Tal istmo correspondente ao lobo intermédio do timo na atual nomenclatura anatômica veterinária (INTERNATIONAL COMMITTEE ON VETERINARY GROSS ANATOMICAL NOMENCLATURE, 2005).

O timo suíno é particularmente o mais desenvolvido entre as espécies de mamíferos domésticos e atinge o seu maior tamanho aos 6 meses de idade. (SACK, 1982; DYCE et al., 2004). Em suínos jovens, o timo se estende caudalmente desde a origem do músculo digástrico, ao longo das artérias carótidas comuns e em ambos 
os lados do pescoço, até a entrada do tórax, onde os lados direito e esquerdo parecem se fundir (Figura 1-A) (VENZKE, 1986). A parte cervical do timo localiza-se lateralmente à laringe e à traquéia; sua terminação cranial é bulbosa e, em sua superfície, contém a pequena (1 a $4 \mathrm{~mm}$ ) glândula parótida externa (III) (SACK, 1982). As duas partes torácicas ocupam a porção cranial do mediastino e, cranialmente em sua face ventral, o órgão está relacionado com o músculo omohióideo (VENZKE, 1986). Schummer et al. (1981) afirmam que no início do desenvolvimento o broto tímico de suínos permanece parcialmente em conexão com a região faríngea, o que permite a origem da parte cervical do órgão nesta espécie.

Publicações clássicas, datadas das duas primeiras décadas do século $X X$ (BELL, 1906; BADERTSCHER, 1915a), trazem descrições minuciosas a respeito da organização e topografia das partes do timo de suínos no decorrer de determinadas fases de desenvolvimento. Em um estudo sobre a morfogênese do órgão em suínos, Badertscher (1915a) relata que no embrião de $21,5 \mathrm{~mm}$ o timo pode ser dividido em sete regiões que, na sua maioria, se tornam muito pronunciadas em estágios mais tardios de desenvolvimento. Neste estudo, as regiões foram designadas com base em um sistema de nomenclatura previamente utilizado por outros autores (KASTSCHENKO, 1887; BELL, 1905; ZOTTERMAN, 1911) e os termos empregados foram: timo superficial, cabeça do timo, faixa conectora, segmento cervical médio, cordão intermediário, cordão cervicotorácico e segmento torácico. A parte chamada de timo superficial foi originalmente descrita por Kastschenko (1887) e representa a vesícula cervical lateral embrionária, quando a vesícula cervical perde a conexão com a ectoderme. Esta parte está conectada à parte chamada de cabeça do timo pela faixa conectora, a qual envolve o nervo hipoglosso em seu trajeto e pode estar ausente em um ou ambos os antímeros após o nascimento. A cabeça do timo é originada pela fusão da vesícula cervical medial com a porção cranial do primórdio endodérmico do órgão. O segmento cervical médio corresponde a um espessamento entre os cordões intermediário e cervicotorácico. Este último se continua na porção cranial do tórax com o segmento torácico, tem conformação achatada e está localizado por sobre parte do pericárdio (BADERTSCHER, 1915a).

Drummond (1996), em seu estudo sobre os aspectos morfométricos e de vascularização arterial do timo em suínos da raça Hampshire, considerou o órgão como sendo constituído de duas partes, uma cervical (pars cervicalis) e outra 
torácica (pars thoracica), com base na terceira edição (1983) da nomenclatura anatômica veterinária. Neste mesmo estudo o autor relatou alguns achados morfológicos interessantes como a ausência de massa tímica no antímero direito de 8 dos 28 animais por ele estudados e a ausência total da parte torácica de 1 dos 30 animais examinados em estudo anterior.

Segundo a publicação mais recente da Nomina Anatomica Veterinaria (N.A.V.) (INTERNATIONAL COMMITTEE ON VETERINARY GROSS ANATOMICAL NOMENCLATURE, 2005), o timo dos animais domésticos é composto de 5 lobos e a nomenclatura convencionada é a seguinte: lobo cervical direito e esquerdo (lobus cervicales dexter et sinister), lobo intermédio (lobus intermedius) e lobo torácico direito e esquerdo (lobus thoracicus dexter et sinister). A topografia e algumas das principais relações sintópicas do timo suíno, assim como a sua lobação, estão representadas na Figura 1. 

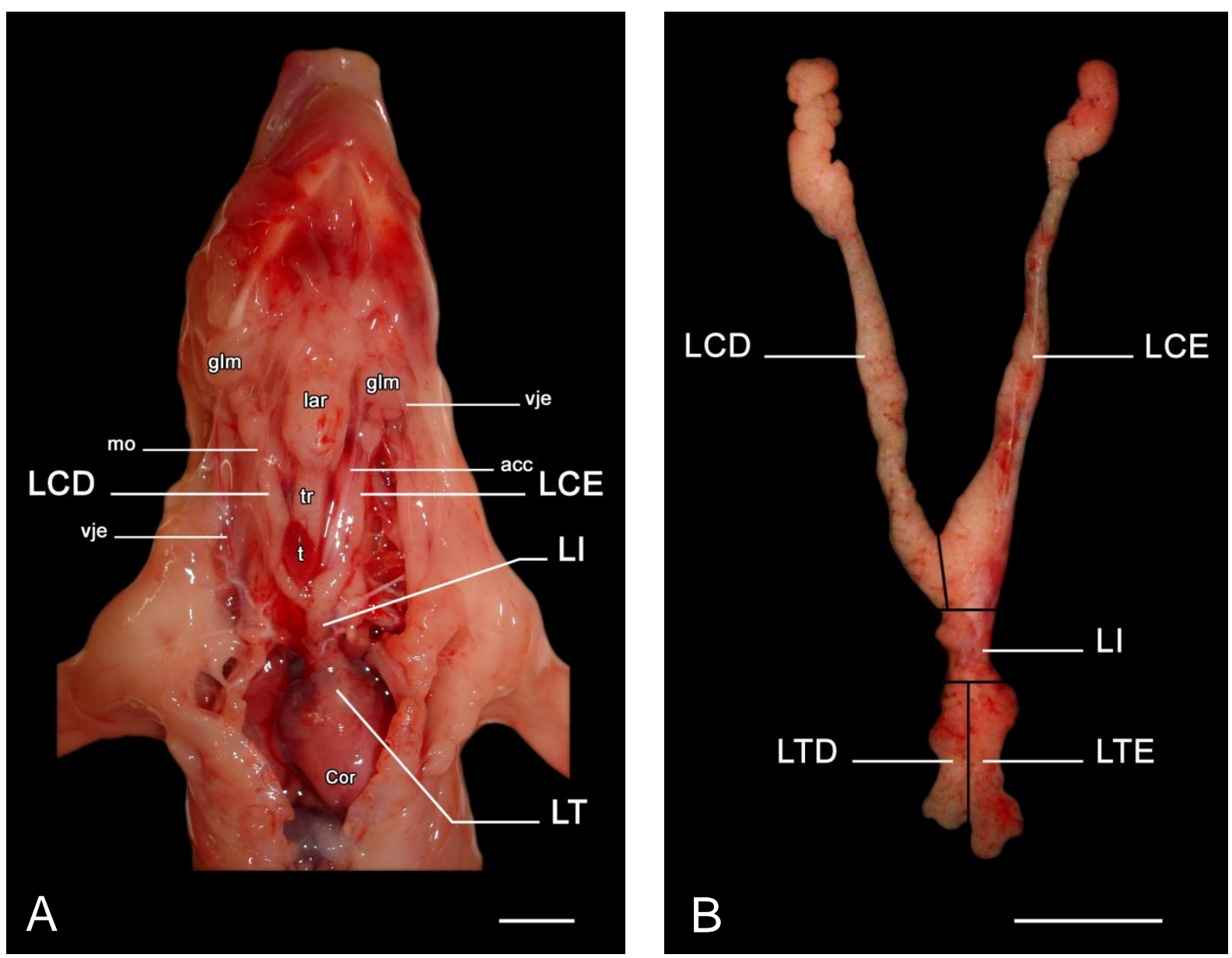

Figura $1(\mathrm{~A}-\mathrm{B})$ - Timo de feto suíno com 65 dias de idade gestacional. Dissecção em peça não fixada, 30 minutos post mortem. A) Vista ventral do timo in situ. B) Vista ventral do timo dissecado e removido do corpo do animal. Linhas pretas indicam limites estimados entre os lobos tímicos, com base na topografia do órgão em A e de acordo com o "International Committee on Veterinary Gross Anatomical Nomenclature" (2005). Legenda: acc, artéria carótida comum (direita); cor, coração; glm, glândula salivar mandibular; lar, laringe; mo, músculo omo-hióideo (esquerdo); t tireóide; tr, traquéia; vje, veia jugular externa (direita e esquerda); LCD, lobo cervical direito; LCE, lobo cervical esquerdo, LI, lobo intermédio; LT, lobos torácicos; LTD, lobo torácico direito; LTE, lobo torácico esquerdo. Barras: $1 \mathrm{~cm}$ 


\subsection{A ORGANOGÊNESE DO TIMO}

A organogênese pode ser dividida em vários estágios distintos: posicionamento, determinação precisa do local onde o órgão rudimentar se desenvolverá no embrião; iniciação, desenvolvimento declarado do órgão rudimentar; amadurecimento e padronização, aparecimento de diferenças regionais no órgão rudimentar em crescimento e, por fim, diferenciação, quando informações espaciais das diferenças regionais se traduzem em distintos tipos celulares. No timo, a organogênese é um processo de desenvolvimento similar ao de outros órgãos, por isso para o seu estudo é útil ter como base os estágios comuns e já definidos do início de tal processo (BLACKBURN; MANLEY, 2004).

Como mencionado por Badertscher (1915b), talvez não haja outro órgão cujo modelo de desenvolvimento tenha gerado tanta contestação e teorias amplamente divergentes como o timo. Entretanto, segundo o mesmo autor, essa disparidade de teorias não pode ser atribuída às diferenças de desenvolvimento do órgão dentre os animais, pois pesquisadores que estenderam suas investigações a uma vasta gama de espécies, pertencentes a diferentes classes, concluíram que o processo de desenvolvimento envolvido é praticamente o mesmo. Apesar disso, até a década atual muito se questionou sobre a origem tímica, até que estudos recentes confirmaram, em camundongos, que a ausência da ectoderme faríngea não impede o completo e organizado desenvolvimento dos compartimentos cortical e medular do órgão, assim como a sua presença não potencializa a capacidade endodérmica da região em gerar tecido tímico (GORDON et al., 2004). Assim, demonstrou-se uma origem tímica unicamente endodérmica, confirmando as fortes evidências de estudos anteriores (MANLEY; BLACKBURN, 2003) que refutavam a participação de células epiteliais ectodérmicas na organogênese do timo.

A segmentação da faringe posterior do embrião constitui o primeiro passo para a formação do timo e inicia uma série de eventos ainda não completamente compreendidos (HOLLÄNDER et al., 2006). Tais eventos resultam na diferenciação de células epiteliais em células tímicas que, em ratos, ocorrem no dia 10,5 do desenvolvimento embrionário. 
O estágio inicial da organogênese tímica é concomitante e intimamente relacionado com o início da organogênese das glândulas paratireóides, que se originam da parte dorsal da TBF. Inicialmente formada a partir do mesmo primórdio, uma partição espacial está presente entre os dois órgãos durante esta fase da organogênese e o epitélio primordial tímico evagina-se do revestimento da TBF, estendendo-se até o tecido subjacente do arco faríngeo (AF) (HILFER; BROWN, 1984). Um folheto interno endodérmico e uma camada externa de células epiteliais de origem ectodérmica recobrem os AFs, constituídos de um núcleo mesenquimal de origem mesodérmica e ectodérmica (GRAHAM; SMITH, 2001). Entretanto, análises da expressão do fator de transcrição Foxn 1 identificaram a endoderme do aspecto ventral da terceira bolsa faríngea (TBF) como o único local de onde o timo primordial emerge (BLACKBURN; MANLEY, 2004).

Em adição à importância do epitélio endodérmico, o mesênquima dos AFs apresenta um equivalente e essencial papel na formação do primórdio tímico. Algumas das células mesenquimais do interior dos AFs são derivadas de expansões celulares da crista neural $(\mathrm{CN})$ e, portanto, referidas como ectomesênquima (KURATANI, 2005). Células da CN contribuem para o mesênquima dos AFs mais caudais (terceiro, quarto e sexto) e também originam o tecido conjuntivo tímico e as glândulas paratireóides. O grau de contribuição do mesênquima derivado da CN para a formação dos AFs parece variar com a localização anatômica destes ao longo do eixo longitudinal do embrião. Isto sugere que as células da CN podem, por si só, carrear uma identidade posicional (HOLLÄNDER et al., 2006).

Estruturas simétricas e temporárias, os AFs surgem progressivamente no desenvolvimento embrionário, obedecendo a uma ordem craniocaudal, com a sua posição inicial ao longo do eixo do embrião e de caráter essencial para a especificação da endoderme no brotamento tímico. A cerca do dia 12,5 do desenvolvimento embrionário murino, o primórdio tímico encontra-se separado da superfície endodérmica do tubo visceral e passa a atrair precursores de células linfóides (HOLLÄNDER et al., 2006).

Com a entrada de células precursoras de linfócitos-T no estroma tímico, uma interação molecular bidimensional é iniciada entre as células linfóides e as células 
epiteliais do órgão e essa interação é essencial para a maturação morfológica e funcional de ambos os compartimentos celulares (KLUG et al., 2002).

\subsection{HISTOLOGIA DO TIMO}

Os aspectos histológicos do timo são comparáveis em todos os vertebrados e baseiam-se em um padrão de órgão lobulado, com uma organização corticomedular (SCHUURMAN; KUPER; KENDALL, 1997). O órgão é envolto por uma delgada cápsula de tecido conjuntivo de onde se originam septos que o dividem parcialmente em lóbulos interconectados (PEARSE, 2006). Os lóbulos tímicos variam em forma, tamanho e orientação, mas cada um é constituído de córtex e medula. O córtex constitui uma grande área periférica e a medula está localizada centralmente. Cada região é caracterizada por uma composição distinta de células estromais e linfóides (RITTER; CRISPE, 1992) e facilmente identificada devido à grande diferença na densidade de linfócitos; muito maior no córtex (SCHUURMAN; KUPER; KENDALL, 1997). O córtex é diferenciado em três áreas principais: região subcapsular (RS), camada cortical externa e camada cortical interna. A junção corticomedular (JCM), região intermediária localizada entre o córtex e a medula, é uma área rica em vasos sanguíneos e alcançada pelos septos conjuntivos, por meio dos quais chegam as artérias. A medula pode formar pequenos gomos que se estendem para o interior do córtex e, algumas vezes, estes podem alcançar as proximidades da cápsula (SCHUURMAN; KUPER; KENDALL, 1997).

O estroma tímico é composto por diversos tipos celulares como fibroblastos, células dendríticas, células endoteliais, miócitos e macrófagos (VAN EWIJK, 1991; GRAY; CHIDGEY; BOYD, 2002), mas principalmente por células reticulares, as células epiteliais tímicas (CETs), caracterizadas pela presença de tonofilamentos e conexões desmossomais. A rede formada por estas células constitui a estrutura de suporte do órgão (PEARSE, 2006) e influencia diferentes aspectos da diferenciação dos timócitos (SAVINO, 2006). As CETs da RS formam uma camada com cerca de uma ou duas células. Na camada externa do córtex as CETs são finas e achatadas, enquanto que nas demais regiões do órgão assumem um aspecto estrelado. São 
divididas em populações distintas que diferem na expressão antigênica e na capacidade de síntese de hormônios tímicos como timulina, timosina, timopoetina e fator tímico humoral (PEARSE, 2006).

De Waal e Remarks (1997) relataram que características imuno-histoquímicas permitem que as CETs sejam classificadas em quatro subtipos: cortical subcapsular, cortical interna, medular e corpúsculos tímicos. Entretanto, os mesmos autores confirmaram em ratos que análises de caracteres ultra-estruturais de CETs revelam maior heterogenicidade, assim como observado inicialmente no timo humano por Van De Wijngaert et al. (1984). Principalmente em concordância com parâmetros de eletrodensidade nuclear e citoplasmática, tanto em humanos como em ratos, são descritas no córtex 4 subpopulações de CETs, classificadas numericamente e sob a designação, respectivamente, de: subcapsular/perivascular (Tipo 1), pálida (Tipo 2), intermediária (Tipo 3) e escura (Tipo 4). Todas estas subpopulações estão presentes também na medula, porém nesta região são encontrados adicionalmente outras 2 subpopulações: indiferenciada (Tipo 5) e cística (Tipo 6) (VAN DE WIJNGAERT et al., 1984; DE WAAL; REMARKS, 1997).

Células do Tipo 1 apresentam grânulos secretórios de hormônios e citocinas, e localizam-se sob a membrana basal da cápsula, contornando os septos e os espaços perivasculares, como também ao redor dos capilares sanguíneos do córtex, contribuindo para a formação da barreira hemato-tímica. Os Tipos 2, 3 e 4 representam estágios diferentes e uma única classe celular na qual o primeiro estágio (Tipo 2) compreende células de grande atividade que se interligam umas às outras por meio de longos prolongamentos citoplasmáticos que englobam coleções de timócitos (VAN DE WIJNGAERT et al., 1984). Este arranjo provê uma ampla área de contato entre as células, permitindo a interação entre as CETs e os timócitos em desenvolvimento. As células do Tipo 4 são CETs eletrodensas que no córtex se concentram principalmente na camada interna (RITTER; CRISPE, 1992). O Tipo 5 é representado por células pequenas e indiferenciadas, encontradas agrupadas em pequenas proporções na medula, enquanto que células do Tipo 6 são grandes, com proeminentes tonofilamentos, apresentam grânulos secretores, citoplasma eletrolucente e núcleo eucariótico arredondado. Características particulares foram observadas entre os mesmo tipos celulares encontrados tanto no córtex como na medula, principalmente nas células medulares tipo 2 e 3 , que apresentam maiores 
tonofilamentos que suas similares no córtex (DE WAAL; REMARKS, 1997). Os tipos 4 e 6 são comumente encontrados em torno e no interior dos corpúsculos tímicos (VAN DE WIJNGAERT et al., 1984) e as do Tipo 6 de ratos são estruturalmente diferentes das correspondentes humanas (DE WAAL; REMARKS, 1997). Em comparação a humanos e primatas, ratos e camundongos apresentam raros e pequenos corpúsculos tímicos (PEARSE, 2006; RAICA et al., 2006).

Os corpúsculos tímicos foram primeiramente descritos pelo médico inglês Arthur Hill Hassal em seu livro publicado em 1849, composto de 2 volumes e intitulado: "The Microscopic Anatomy of the Human Body in Health and Disease", uma das primeiras obras dedicadas à histologia (ORTIZ-HIDALGO, 1992). Os corpúsculos tímicos são estruturas formadas por células epiteliais dispostas de forma concêntrica e se localizam na região medular do órgão. Estudos clássicos os descreveram como estruturas acidófilas, variáveis em tamanho e número, comumente exibindo características degenerativas em sua área central como necrose, debris celulares, calcificações e formações císticas. Estas observações conduziram à hipótese prematura de que os corpúsculos tímicos representavam uma forma de degeneração do componente epitelial do órgão (RAICA et al., 2006).

Estudos mais recentes demonstraram que as células epiteliais dos corpúsculos tímicos são ativas na secreção de citocinas e fatores de crescimento (NISHIO et al., 2001). Zaitseva et al. (2002) identificaram o fator derivado de estroma-1 (SDF-1) (indutor da migração de leucócitos e células progenitoras hematopoiéticas nos sistemas imune e nervoso) em corpúsculos tímicos humanos e sugeriram uma potencial ação deste fator na sinalização de células dendríticas para a eliminação de timócitos em apoptose. Ainda no tocante à atividade dos corpúsculos tímicos no microambiente tímico, vários autores tem demonstrado que células epiteliais de corpúsculos tímicos expressam linfopoetina estromal tímica (TSLP), interleucina crucial para o desenvolvimento de linfócitos B e T, e ativadora de subpopulações de células dendríticas envolvidas na seleção positiva e negativa de timócitos (TARBELL et al., 2004; WATANABE et al., 2005). A diferenciação de timócitos $\mathrm{CD}^{+} \mathrm{CD} 25^{+}$requer a sinalização do ligante CD28, presente em células TSLP positivas. Watanabe et al., (2005) demonstraram que o cultivo de células dendríticas com timócitos, na presença de TSLP, aumentou em mais de 10 vezes o número dessa população de timócitos. Assim, Raica et al. (2006) apoiaram a 
hipótese de que os corpúsculos tímicos são estruturas ativas no processo de maturação e seleção de linfócitos (WATANABE et al., 2005) ao demonstrarem a presença de células dendríticas maturas entre as células epiteliais de corpúsculos tímicos, por meio de imuno-histoquímica para \$100, proteína específica para marcação deste tipo celular. Células dendríticas imaturas são encontradas isoladamente no córtex tímico, mas em grande quantidade na junção corticomedular e medula. Estudos de Raica et al. (2006) confirmaram que células dendríticas imaturas são ativadas na medula pela sinalização advinda dos corpúsculos tímicos, o que aponta para um papel essencial das células dendríticas positivas para TSLP da junção corticomedular na seleção negativa de células $\mathrm{T}$ e da região central da medula na seleção positiva de células auto-reativas.

\subsection{INVOLUÇÃO TÍMICA}

Com o avanço da idade o timo sofre um processo morfofisiológico de involução que determina alterações da arquitetura normal do órgão, como por exemplo, perda do padrão de JCM bem como diminuição do número de células estromais, as quais representam a força motriz da timopoiese (LEPOSAVIĆ; PERIŠIĆ, 2008). De acordo com Douek et al. (1998), apesar da redução da área funcional tímica, o timo em involução ainda demonstra maturação de células $\mathrm{T}$, porém em menor escala. Associadas à diminuição da produção de células $\mathrm{T}$, também estão presentes uma redução no envio de precursores da medula óssea ao timo e uma modificação do perfil de expressão gênica e protéica entre as diferentes populações de linfócitos T (LEPOSAVIĆ; PERIŠIĆ, 2008). Em ratos, a perda do epitélio tímico ocorre por diminuição gradual do seu tamanho (SEMPOWSKI et al., 2001), porém em humanos a involução do órgão é caracterizada por um aumento do espaço perivascular que progressivamente é preenchido por tecido gorduroso (FLORES et al., 1999). Padrão de involução semelhante ao de humanos, por deposição de gordura, é relatado em mamíferos domésticos (SCHUMMER et al., 1981). 
Nos mamíferos, a involução fisiológica coincide com o início da puberdade, estágio este associado ao aumento da concentração circulante de hormônios sexuais gonadais (BODEY et al., 1997). O aumento dos níveis desses hormônios em roedores de ambos os sexos causa atrofia do timo, semelhante ao observado durante o envelhecimento (KUHL, 1983; YELLAYI, 2002), enquanto que a gonadectomia adia este processo e reverte as alterações associadas à depleção do órgão (HINCE et al., 2008).

Brelinska et al. (2008) afirmam que mesmo com o equivalente a 18 ou 24 meses de idade, o que corresponde a, respectivamente, a aproximadamente 75 e $100 \%$ de sua expectativa de vida, as alterações morfológicas descritas para a involução do timo em ratos não indicam perda completa de sua função, mas sim uma diminuição significativa do volume cortical e aumento do volume de tecido conjuntivo do órgão, além de redução do peso à metade do peso original.

A deterioração do sistema imune pela progressão da idade é comumente associada à consequências clínicas como aumento da morbidade e mortalidade durante processos infecciosos (CASTLE, 2000), bem como maior incidência de câncer e doenças autoimunes, além de resposta reduzida a vacinações (GOLDBERG et al., 2007; HINCE et al., 2008).

Não há dúvidas quanto à modulação da timoipoiese pelos hormônios esteróides andrógenos e estrógenos. Entretanto, ainda não é esclarecido se mudanças na sua produção consistem nas bases para a involução tímica, pois experimentos demonstraram que os efeitos da ablação gonadal em camundongos machos e fêmeas durante a puberdade são prolongados, mas não permanentes, mostrando que há um adiamento na atrofia tímica e consequente deterioração do sistema imune com a idade, mas não prevenção da involução do órgão (MIN et al., 2006; PESIC et al., 2007).

O processo de formação, crescimento e involução de um órgão correlacionase diretamente com o aporte sanguíneo e, portanto com a vascularização. Brelinska et al. (2008), em um estudo temporal que avaliou a arquitetura tímica em ratos, relataram que as primeiras modificações relacionadas à idade se iniciaram em proximidade direta com o tecido conjuntivo e com os vasos sanguíneos do órgão, 
por meio do contato com determinadas subpopulações de CET que expressavam imunoreatividade ao polipeptídeo de citoqueratina 8 (Ck-8). Segundo estes autores, diferenças de imunoreatividade a este e outros polipepetídeos citoqueratínicos desenvolvem-se em paralelo com a perturbada diferenciação de timócitos que ocorre com o avanço da idade, já que as CET são células moduladoras deste processo. Além disso, as mudanças mais dinâmicas foram observadas no córtex, que apresentou expressiva redução de volume, enquanto que o volume medular não foi significativamente afetado, corroborando com observações de estudos anteriores que analisaram a morfometria dos compartimentos anatômicos do timo durante a involução.

Na espécie suína é relatado que o ápice do desenvolvimento tímico é alcançado por volta dos 6 meses e o seu processo de involução é iniciado aos 12 meses de idade (SACK, 1982; DYCE et al., 2004). Entretanto, devido ao sistema de criação intensiva e abate precoce destes animais, são poucos os dados sobre a involução morfológica e funcional do órgão na espécie.

\subsection{REGENERAÇÃO TÍMICA}

O processo gradual de involução pode ser acelerado de forma aguda em resposta a diversos estímulos como doença, estresse severo, radiação ionizante, hormônios adrenocorticotrópicos, esteróides sexuais, toxinas bacterianas e agentes citotóxicos como drogas antineoplásicas. (LEE et al., 2007). Sob qualquer uma destas condições, o timo rapidamente diminui em tamanho devido à massiva morte de timócitos e a imunidade pode ser conseqüentemente suprimida, aumentando a suscetibilidade do organismo a doenças (LEE et al., 2007).

Tem sido bem documentado que a involução aguda induzida experimentalmente em modelos animais é seguida de intensa regeneração quando removido o estímulo causador. Assim, as células epiteliais, que se apresentam achatadas durante o tratamento com drogas antineoplásicas, recuperam sua forma arredondada e características compatíveis com alto índice de síntese protéica (YOON et al., 1997), além de expressarem em grande quantidade a proteína RANKL 
(ligante do ativador do receptor do fator nuclear kß) (LEE et al., 2005), indispensável para o desenvolvimento inicial dos linfócitos $\mathrm{T}$, interação entre estes e células dendríticas, além de modular a própria função destas últimas (KONG et al., 1999). A expressão tecidual da proteína RANKL durante a regeneração do timo foi localizada principalmente em células perivasculares o que indica uma provável participação do mesmo como agente de indução de fatores promotores da vascularização tímica (LEE et al., 2005).

De acordo com Lee et al. (2007) o fator de crescimento nervoso (NGF) é um potente imunomodulador, promovendo comunicação cruzada entre vários tipos de células do sistema imune e, no timo em regeneração, é significantemente regulado por alguns tipos de células epiteliais tímicas (subcapsulares, paraseptais e perivasculares).

Park et al. (2007) relatam que o timo em ratos tratados com ciclofosfamida (imunossupressor utilizado em larga escala atualmente) apresenta recuperação total da massa inicial após 14 dias da suspensão do tratamento, a qual é acompanhada por aumento da vascularização do órgão concomitantemente ao aumento da expressão do VEGF, o principal fator de crescimento associado à formação de vasos (vasculogênese) ou neovascularização (angiogênese).

\subsection{VASCULARIZAÇÃO TÍMICA}

Os vasos sangüíneos do timo apresentam uma arquitetura típica, caracterizada por grandes vasos localizados na junção corticomedular e uma fina cadeia de ramificações e anastomoses no interior do córtex (ANDERSON et al., 2000), entretanto as bases moleculares que induzem a formação desta típica vascularização tímica é desconhecida (MÜLLER et al., 2005).

Arteríolas que suprem o timo chegam pela base dos septos, na região da junção corticomedular e originam três principais conjuntos vasculares no interior do órgão, sendo que dois deles suprem o córtex. Um desses conjuntos forma capilares que passam por todo o córtex e chegam à cápsula, onde formam alças e retornam 
para o interior do córtex até finalmente atingirem a junção corticomedular e deixarem o órgão como vênulas. O outro conjunto origina capilares que passam pelo córtex, saem pela cápsula e drenam para plexos venosos localizados logo externamente ao órgão, próximo à cápsula. O terceiro conjunto vascular nutre a medula e forma alças capilares que partem do órgão via vênulas na junção corticomedular. Algumas dessas vênulas são revestidas com endotélio cubóide ao invés de células achatadas, o que é associado à migração de linfócitos. Tais vasos são chamados de vênulas de endotélio alto e correspondem ao local de entrada e saída de células linfóides no órgão. Vasos linfáticos promovem a drenagem da cápsula, septos e espaços perivasculares. Fibras nervosas acompanham os vasos para o interior do órgão através dos septos e formam plexos na junção corticomedular e na região subcapsular (RITTER; CRISPE, 1992).

Uma barreira hemato-tímica previne a entrada de macromoléculas como antígenos no interior do órgão. Suas bases estruturais são compostas por CETs do tipo 1 que envolvem os capilares corticais, juntamente com as junções ocludentes do endotélio capilar. Os capilares do córtex apresentam raras fenestrações, portanto a existência da barreira hemato-tímica não significa que o timo seja impermeável a macromoléculas externas (RITTER; CRISPE, 1992), mas é capaz de restringir o acesso de moléculas antigênicas aos linfócitos corticais em desenvolvimento (PEARSE, 2006).

\subsection{VASCULOGÊNESE E ANGIOGÊNESE}

A formação de vasos sanguíneos ocorre por meio de dois processos distintos e consecutivos: vasculogênese e angiogênese. O primeiro destes processos, vasculogênese, corresponde à formação de capilares sanguíneos primitivos, desencadeada pela diferenciação in situ de células-tronco hemangiogênicas, derivadas de células mesenquimais pluripotentes, as células progenitoras hemangiogênicas (DEMIR, 2009). Posteriormente as células-tronco hemangiogênicas se diferenciam em células-tronco hemangioblásticas que, por sua vez, originam células angioblásticas, progenitoras de células endoteliais (HANAHAN, 
1997; RIBATTI et al., 2002; DEMIR, 2007) e células hemangioblásticas, progenitoras de células hematopoiéticas (DEMIR, 2007).

O processo subsequente, angiogênese, corresponde à formação de novos vasos a partir dos vasos já existentes (PLENDL, 2000) e acontece por meio de quebra de membrana basal dos capilares por secreção e migração de proteases, além da indução da proliferação de células endoteliais, eventos estes estimulados pelo VEGF, o mais potente indutor da vasculogêse e da angiogênese (REYNOLDS; REDMER, 2001).

O processo de vasculogênese no timo ocorre durante o desenvolvimento embriológico, quando vasos sanguíneos penetram no interior do parênquima do órgão, acompanhando o tecido conjuntivo derivado da cápsula e formando espaços perivasculares ao redor dos vasos (KATO, 1997).

O papel do endotélio vascular tímico tem sido considerado como limitado à função de via de acesso ao órgão para células precursoras de linfócitos originadas da medula óssea e pouca atenção têm sido dada aos possíveis mecanismos de interação que podem regular o compartimento vascular tímico e o papel do endotélio no desenvolvimento do órgão (CUDDIHY et al., 2009).

Agreste (2005), em um estudo que quantificou a vascularização tímica de fetos de cães em diferentes fases de desenvolvimento, sugere que o processo de angiogênese no timo destes animais esteja relacionado com a proximidade ao nascimento, período no qual foi detectado um aumento da rede vascular do órgão.

\subsection{SISTEMA VEGF-A E SEUS RECEPTORES}

O VEGF, primeiramente denominado fator de permeabilidade vascular (VPF), foi isolado pela primeira vez do líquido ascítico de cobaias (SENGER et al., 1986). fator de crescimento endotelial - A (VEGF-A) é o primeiro e melhor descrito membro da família dos VEGFs que, além desta, contém mais 4 proteínas: VEGF-B (OLOFSSON et al., 1996; PAAVONEN et al., 1996), VEGF-C (JOUKOV et al., 1996), VEGF-D (ACHEN et al., 1998) e VEGF-E (ACHEN et al., 1998). Até o momento 
foram identificadas em seres humanos oito isoformas do VEGF-A (VEGF121, VEGF145, VEGF148, VEGF165, VEGF165b, VEGF183, VEGF189 e VEGF206) que são geradas por derivação alternativa de um único gene e nomeadas de acordo com a quantidade de aminoácidos que cada molécula de proteína secretada possui (BATES; HARPER, 2002; LANGE et al., 2003).

O VEGF é um mitógeno específico para células endoteliais e responde por um importante papel na regulação do desenvolvimento vascular, sob condições normais e patológicas in vitro e in vivo (PHILIPS et al., 1990; DVORAK et al., 1991). Além da atividade angiogênica, o VEGF também apresenta atividade próinflamatória e neuroprotetora (FERRARA et al., 1996).

Dois receptores para VEGF-A pertencentes à família de receptores tirosinaquinase foram identificados e clonados: o receptor 1 do fator de crescimento endotelial vascular (VEGFR-1) ou também chamado de receptor 1 de tirosinaquinase semelhante a fms (Flt-1) (DE VRIES et al., 1992) e o receptor 2 do fator de crescimento endotelial vascular (VEGFR-2) ou também chamado de receptor de domínio de inserção de quinase (KDR) (TERMAN et al., 1992). Juntamente com o receptor 3 do fator de crescimento endotelial vascular (VEGFR-3) ou também chamado de receptor 4 de tirosina quinase semelhante a fms (Flt-4), que foi primeiramente identificado apenas em vasos linfáticos (JUSSILA et al., 1998), o Flt-1 e o KDR formam uma subfamília distinta pela presença de sete alças semelhantes à imunoglobulina em sua porção extracelular e um domínio bipartido de tirosinaquinase em sua porção intracelular (FOURNIER et al., 1997). Estes receptores são expressos predominantemente em células endoteliais, mas alguns poucos outros tipos celulares podem expressar um ou ambos os tipos de receptores sugerindo outras funções celulares desempenhadas pelo VEGF.

A cascata de transdução do sinal induzido pelo Flt-1 é diferente daquela do KDR. A ativação do KDR pelo VEGF em células desprovidas de Flt-1 resulta em resposta mitogênica, enquanto que a ativação do Flt-1 em células desprovidas de KDR não induz proliferação. No entanto, a ativação do Flt-1 pelo VEGF induz migração celular, resposta que também é obtida a partir da ativação do KDR pelo VEGF (YOSHIDA et al., 1996). 
A expressão do sistema VEGF-A no timo murino foi demonstrada em células epiteliais de animais neonatos (CUDDIHY et al., 2009) e jovens (PARK et al., 2007), como também em timócitos de neonatos (CUDDIHY et al., 2009). Nestes, ambos os receptores (Flt-1 e KDR) foram localizados em células epiteliais, enquanto que no endotélio apenas o KDR (CUDDIHY et al., 2009). Os mesmos autores demonstraram que a inibição deste fator provocou perda rápida da densa rede de capilares do timo e acentuada redução do número de timócitos, o que sugere um papel determinante do VEGF na timopoiese em estágios iniciais do desenvolvimento neonatal. No timo humano adulto normal o VEGF foi localizado em células epiteliais da região subcapsular e também nos corpúsculos tímicos (CIMPEAN et al., 2008). Atualmente se atribui a este fator o papel de imunoregulador e modulador do microambiente tímico (KISELEVA et al., 2005). O VEGF-C, indutor primário da linfangiogênese, não foi localizado em tecido tímico humano (JOORY et al., 2006), apesar de relatos consistentes sobre a vascularização linfática deste tecido (KATO, 1997).

\subsubsection{As Interações Celulares e a Modulação do Ambiente Tímico pelo VEGF}

O timo, órgão linfóide central para o desenvolvimento de células $\mathrm{T}$, originadas de células precursoras da medula óssea, pode ser o local de integração de diferentes redes auto-imunes que estão potencialmente envolvidas na regulação do desenvolvimento dessas células. Além disso, o estroma tímico provê um microambiente especializado na sobrevivência, proliferação, diferenciação e maturação das células T (LEE et al., 2007).

O timo é divido em compartimentos morfológica e funcionalmente distintos. $\mathrm{O}$ córtex apresenta alta celularidade e contém timócitos inicialmente CD4- CD8 (duplo negativo, DN) e também $\mathrm{CD}^{+} \mathrm{CD}^{+}$(duplo positivo, DP) imaturos, sujeitos à seleção positiva pelo epitélio cortical. A medula, de celularidade mais baixa, apresenta timócitos em estágio de maturação mais avançado, os quais são submetidos à seleção negativa pelas células dendríticas e epitélio medular. As células DN apresentam pelo menos 4 estágios de desenvolvimento, sendo que o VEGF é expresso nos estágios intermediários nos animais neonatos, mas não nos estágios inicial e final (CUDDIHY et al., 2009). Ao final da maturação, na medula, há a perda 
de um ou outro marcador, o que torna o timócito $\mathrm{CD}^{-} \mathrm{CD}^{+}$ou $\mathrm{CD}^{+}{ }^{+}$CD8 ${ }^{-}$ (PROCKOP; PETRIE, 2000). Outras populações celulares tímicas em neonatos também apresentam expressão do VEGF, como é o caso das células epiteliais, estromais e hematopoiéticas. Animais adultos, por outro lado, não apresentaram reação positiva para VEGF em nenhum dos tipos celulares mencionados e testes de expressão de mRNA também falharam ao tentar detectar VEGF em timos de camundongos adultos (CUDDIHY et al., 2009).

A importância do VEGF para manutenção do padrão vascular no adulto e no neonato também varia. No neonato, não apenas o arranjo vascular tímico é determinado pela expressão de VEGF como também a quantidade de timócitos. No entanto, a proliferação e a apoptose celular são eventos independentes da expressão deste fator de crescimento. Em neonatos o endotélio tímico e os timócitos interagem por meio da secreção do VEGF e influenciam um ao outro, o que acontece em menor escala no animal adulto. Ainda em neonatos, o receptor KDR é expresso nas células endoteliais em $33 \%$ e epiteliais em $11 \%$ dos casos, porém em adultos é expresso, respectivamente, em 5\% e 1\% dos casos. Os timócitos não apresentam evidências da expressão de KDR, o que aponta para uma ação indireta do VEGF sobre estas células. Ao contrário, os timócitos são capazes de influenciar as células endoteliais para que, em resposta ao VEGF, aumentem sua fenestração e possibilitem a migração de linfócitos T. Esta resposta diminui em função do amadurecimento do órgão, que passa a apresentar vasos menos responsivos ao VEGF, além de maior quantidade de pericitos ao redor dos mesmos (CUDDIHY et al., 2009). 
MATERIAIS E MÉTODOS 


\section{MATERIAIS E MÉTODOS}

O detalhamento pertinente aos materiais e aos métodos empregados neste estudo está disposto nas seções que se seguem no decorrer deste capítulo.

\subsection{ORIGEM DAS AMOSTRAS E LOCAIS DO EXPERIMENTO}

Para o desenvolvimento desta pesquisa foram utilizados timos de 25 suínos (Sus scrofa domestica), dos quais 5 eram matrizes Naïma Pen $\operatorname{Ar~Lan~}^{1}$ e os outros 20 contemplaram 15 fetos e 5 leitões descendentes dessas matrizes. Os animais formam oriundos da granja experimental da Faculdade de Medicina Veterinária e Zootecnia da Universidade de São Paulo (FMVZ-USP), Campus de Pirassununga, e do abatedouro comercial Frigogil, localizado na cidade de Rio Claro, São Paulo.

O processamento do material para imuno-histoquímica e PCR em tempo real foi realizado no Laboratório para Estudos Morfofuncionais e Endocrinologia (LEME) do Setor de Anatomia dos Animais Domésticos e Silvestres do Departamento de Cirurgia da Faculdade de Medicina Veterinária e Zootecnia da Universidade de São Paulo (FMVZ-USP), com a colaboração e sob a supervisão da Profa. Dra. Paula de Carvalho Papa. A quantificação vascular por meio de técnica estereológica foi realizada no Laboratório de Morfometria e Morfologia Cardiovascular (LMMC) do Departamento de Anatomia do Instituto de Biologia Roberto Alcântara Gomes (IBRAG) do Centro Biomédico da Universidade Estadual do Rio de Janeiro (UERJ), sob supervisão do Prof. Dr. Carlos Alberto Mandarim-de-Lacerda.

\footnotetext{
${ }^{1}$ Pen Ar Lan Brasil Ltda.
} 


\subsection{A LINHAGEM NAÏMA PEN AR LAN}

Naïma Pen Ar Lan é uma matriz desenvolvida na França, a partir de 75\% de linhagem Redone e $25 \%$ de sangue chinês, o que confere às fêmeas características maternais acima da média: no Brasil estes animais chegam a desmamar 11,1 leitões por leitegada enquanto a média nacional gira em torno de 10 leitões. Além da prolificidade, estas matrizes apresentam qualidade de carcaça compatível às linhagens Large-White e Landrace, conforme indicam os dados de estudo comparativo realizado na Alemanha, país altamente exigente em relação à criação e comercialização de suínos (NAVEAU, 2007). Adicionalmente, desde 1991 a linhagem Pen Nar Lan é livre do gene halotano (NAVEAU, 2006; LÖWEN, 2009), responsável pela resposta aguda dos suínos ao estresse e consequente morte súbita em animais de abate, como também pelas carnes tipo PSE ("pale", "soft", "exudative"). A eliminação deste gene conferiu à linhagem maior capacidade adaptativa (BRETAGNE, 2009). Em 1994 o gene RN (rendimento Napole), descoberto pela própria empresa Pen Nar Lan em 1985 e responsável pela carne ácida e de baixo rendimento ao cozimento, foi eliminado da linhagem Pen Ar Lan (NAVEAU, 2006).

\subsection{DEFINIÇÃO DOS GRUPOS EXPERIMENTAIS}

Os animais foram distribuídos em 5 grupos de acordo com a idade (Quadro 1). Os três primeiros grupos foram constituídos por animais em fases pré-natais de desenvolvimento, ou seja, por fetos em diferentes estágios gestacionais, de modo que, no Grupo 1, foram agrupados os fetos com 65 dias, no Grupo 2 os fetos com 85 dias e, no Grupo 3, os fetos com 111 dias. Nos Grupos 4 e 5 foram agrupados, respectivamente, leitões fêmeas com 5 meses e matrizes com média de 2 anos de idade. Cada um dos grupos pré e pós-natais foi constituído de 5 animais 


\begin{tabular}{|ccc|}
\hline $\begin{array}{c}\text { Grupos } \\
\text { Experimentais }\end{array}$ & Idade (dias) & Número de animais / Sexo \\
\hline Grupo I & $65^{*}$ & $5 / 3$ machos e 2 fêmeas \\
Grupo II & $85^{*}$ & $5 / 3$ machos e 2 fêmeas \\
Grupo III & $111^{*}$ & $5 / 3$ machos e 2 fêmeas \\
Grupo IV & $150^{* *}$ & 5 / fêmeas \\
Grupo V & $730^{* *}$ & 5 / fêmeas \\
\hline * idade gestacional; ** dias de vida pós-natal &
\end{tabular}

Quadro 1 - Divisão dos grupos experimentais por idade e indicação do número de animais por grupo e sexo

O lobo cervical esquerdo do timo de cada feto foi destinado ao estudo quantitativo por estereologia, enquanto que partes dos lobos cervical direito, intermédio e torácicos foram preparadas de acordo com protocolos de imunohistoquímica e quantificação de mRNA por PCR em tempo real. Devido à impossibilidade de dissecção em linha de abate, dos animais dos grupos pós-natais foi coletado apenas o lobo torácico, do qual fragmentos foram destinados às técnicas de imuno-histoquímica, PCR em tempo real e estereologia.

\subsection{COLETA DAS AMOSTRAS}

Os fetos foram obtidos do abate de matrizes prenhes de descarte, criadas e inseminadas no Laboratório de Pesquisa em Suínos do Departamento de Nutrição e Produção Animal (VNP) da FMVZ-USP, Campus de Pirassununga, sob coordenação do Prof. Dr. Aníbal de Sant'Anna Moretti, e abatidas no abatedouro-escola da referida Faculdade. Amostras do timo de todos os animais dos Grupos 4 e 5 foram coletadas no abatedouro Frigogil. 


\subsection{ESTEREOLOGIA}

A estereologia provê formas minuciosas, perspicazes e altamente eficientes de caracterizar uma gama completa de estruturas biológicas (DOCKERY; FRAHER, 2007) e o seu objetivo é determinar parâmetros quantitativos tridimensionais de estruturas anatômicas, a partir de cortes bidimensionais. Para isso vale-se da geometria e da estatística (MANDARIM-DE-LACERDA, 1995).

\subsubsection{Processamento do Material para Estereologia}

Para a estimativa das variáveis estereológicas, o lobo cervical esquerdo do timo de cada animal dos grupos pré-natais (65, 85 e 111 dias de idade gestacional) e parte do lobo torácico do timo de cada animal dos grupos pós-natais (5 meses e 2 anos de idade) foram coletados e fixados em solução de formol tamponado a $4 \%$ por 24 horas. Após esse período foram lavados e armazenados em PBS até serem submetidos ao protocolo para obtenção de cortes verticais proposto por Baddeley, Gundersen e Cruz-Orive (1986).

\subsubsection{Cortes Verticais}

O método de cortes verticais visa reduzir ou eliminar erros sistemáticos de amostragem e promover a isotropia da amostra quando analisada sob um sistemateste. Está baseado no simples fato de que toda linha reta em um espaço de três dimensões (3D) pode ser contida em um único plano vertical. Assim, cortes verticais são cortes perpendiculares e ortogonais a um determinado plano horizontal e, se as secções verticais forem efetuadas de forma uniformemente randômica, as linhas de teste serão aleatórias e uniformemente isotrópicas em 3D. O conceito de planos e cortes verticais está representado de forma esquemática na Figura 2. 
Para se aplicar o método, quatro premissas foram estabelecidas por seus autores (BADDELEY; GUNDERSEN; CRUZ-ORIVE, 1986): 1) o órgão ou tecido deve possuir um eixo vertical, caso contrário este deve ser convencionado; 2) todos os cortes verticais devem ser paralelos ao eixo vertical e a direção vertical deve ser identificada em cada corte; 3) os cortes verticais devem ter posições e orientações randômicas em torno do eixo vertical; 4) sobre os cortes verticais devem ser usados sistemas-tese de arcos-ciclóides, com seu eixo menor alinhado ao eixo vertical do corte.

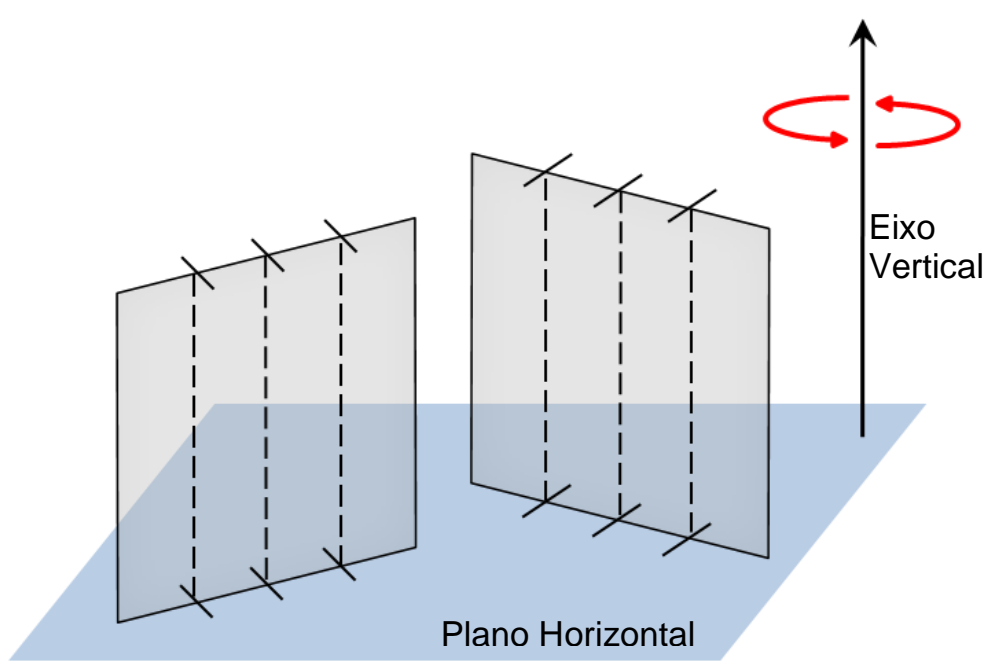

Figura 2 - Representação esquemática do conceito de planos e cortes verticais. Dois planos verticais, paralelos e ortogonais ao eixo vertical de um plano arbitrário horizontal são seccionados por cortes verticais (linhas tracejadas) paralelos entre si (posição representada pelas linhas curtas cheias nas extremidades das linhas tracejadas) em cada plano. Fonte: adaptado de Baddeley, Gundersen e Cruz-Orive (1986)

Os lobos tímicos destinados ao processamento por cortes verticais foram dispostos em uma superfície plana sobre uma mesa e o eixo vertical foi definido como perpendicular à superfície. Com o auxílio de uma lâmina cortante, foram efetuados no lobo cortes paralelos entre si e ao eixo vertical. Os cortes foram orientados de forma ortogonal ao eixo vertical, ou seja, sob um ângulo aleatório. $\mathrm{O}$ número de cortes e, consequentemente de fatias, variou dependendo do tamanho 
do órgão e diferiu entre as idades estudadas, mas a distância entre cortes foi definida de modo que permitisse a realização de outros cortes verticais em cada fatia obtida. As fatias resultantes foram então novamente cortadas por meio de cortes verticais orientados da mesma forma como os primeiros. Esse processo se repetiu até a obtenção de uma fatia de tamanho ideal para inclusão. A inclusão das fatias finais foi feita de modo que o eixo vertical pudesse ser identificado nas secções histológicas observadas à microscopia de luz. Para isso foram usadas como referência as superfícies externas dorsal e/ou ventral do lobo sobre a mesa, antes do processamento, e uma das faces de corte foi posicionada no meio de inclusão de forma a apresentar orientação paralela ao sentido do corte em micrótomo. A representação esquemática da sequência esquemática de cortes verticais está representada na Figura 3. 
A
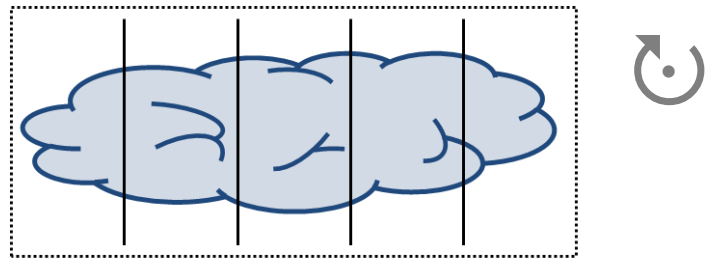

B
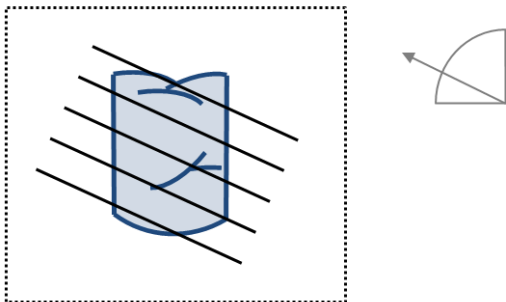

C

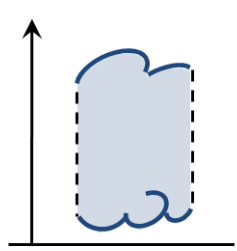

Figura $3(A-C)$ - Representação esquemática da sequência de processamento de material para obtenção de cortes verticais. A) Vista dorsal do material a ser cortado. A área pontilhada representa o plano horizontal e o eixo vertical está representado por um ponto $(\bullet)$ à direita; seta circular $(U)$ indica as possibilidades randômicas de orientação paralela e ortogonal dos cortes (linhas contínuas) em relação ao eixo vertical; linhas cheias representam a posição paralela ente si dos primeiros cortes verticais. B) Fragmento central obtido pelos cortes em A, seccionado sistematicamente em fatias por cortes verticais. Linhas cheias representam cortes verticais paralelos entre si e a um ângulo aleatório (representação à direita), paralelo ao eixo vertical. C) Vista de uma das faces de corte de um fragmento obtido em B. A direção do eixo vertical é indicada pela seta perpendicular à linha (plano horizontal). O sistemateste de arcos ciclóides deve ser alinhado na direção do eixo vertical. Linhas cheias azuis representam as superfícies originais (dorsal e ventral) do material. Linhas tracejadas representam as intersecões das superfícies artificiais criadas pelos cortes verticais. Fonte: adaptado de Mayhew (1991)

\subsubsection{Inclusão e Secção dos Tecidos}

Os tecidos foram desidratados em uma série de etanol em concentrações crescentes (70\%, 90\%, absoluto I, II e III, uma hora cada) e a diafanizados em xilol 
(xilol I, II e III, uma hora cada). A inclusão em Paraplast ${ }^{\circledR}$ Plus $^{1}$ (I, II e de inclusão, 1 hora cada) foi realizada sob protocolo convencional.

Cinco secções $(4 \mu \mathrm{m})$ transversais e não consecutivas de cada amostra incluída foram obtidas em micrótomo e dispostas em lâminas silanizadas, antes de serem submetidas à imuno-histoquímica da laminina para a imunolocalização dos vasos tímicos. Foram desprezadas dez secções entre cada secção aproveitada.

\subsubsection{Silanização das Lâminas}

As lâminas utilizadas foram previamente sinalizadas por meio de banho de imersão em 3-aminopropil-trietoxy-silano (APTES) ${ }^{2}$ a $4 \%(1 \times 1 \mathrm{~min})$, diluído em acetona. Após o período de imersão seguiram-se duas rinsagens consecutivas em acetona e duas rinsagens consecutivas em água destilada, para então as lâminas serem secas à temperatura ambiente por 24 horas e posteriormente armazenadas.

\subsubsection{Imuno-histoquímica da Laminina}

Para a precisa identificação dos vasos sanguíneos tímicos, necessária para a eliminação de erros sistemáticos na quantificação estereológica, optamos por realizar a imunomarcação dos vasos presentes nas secções histológicas do órgão. Após um teste piloto, o anticorpo policlonal anti-laminina PU078-UP ${ }^{3}$ demonstrou-se satisfatório para a imunomarcação desejada e foi empregado no processamento para imuno-histoquímica de todas as lâminas a serem utilizadas no estudo estereológico.

\footnotetext{
${ }^{1}$ McCormick Scientific LLC, Maryland Heights, MO, USA

${ }^{2}$ Sigma-Aldrich ${ }^{\circledR}$ Co., St. Louis, MO, USA

${ }^{3}$ BioGenex, San Ramon, CA, USA
} 
A laminina é uma glicoproteína que corresponde a um dos principais componentes de membranas basais e, segundo Hallmann et al. (2009), suas diferentes isoformas, que transmitem diferentes sinais em diferentes tecidos, a tornam o componente de maior atividade biológica em membranas basais.

As membranas basais são matrizes extracelulares altamente especializadas, associadas a diversos processos celulares como diferenciação, migração e polarização (SOTTILE, 2004). A membrana basal de vasos sanguíneos se localiza subjacente ao endotélio, revestindo pericitos associados, mas também envolvendo células da musculatura lisa de artérias e veias (HALLMANN et al., 2009).

A reação de imuno-histoquímica da laminina seguiu o protocolo utilizado para a reação de imuno-histoquímica do VEGF e seus receptores Flt-1 e KDR, descrito detalhadamente na seção 4.6 deste capítulo, mas com a utilização do anticorpo policlonal anti-laminina PU078-UP como anticorpo primário.

\subsubsection{Sistemas-teste para a Quantificação Vascular}

Os sistemas-teste são constituídos de linhas-teste, pontos-teste e molduras ou áreas-teste de comprimento $\left(\mathrm{L}_{T}\right)$, número $\left(\mathrm{P}_{T}\right)$ e área $\left(\mathrm{A}_{T}\right)$ conhecidos, respectivamente. Estes sistemas são empregados para a obtenção de informações necessárias para a estimativa de variáveis estereológicas como densidade de volume $\left(V_{v}\right)$, densidade de comprimento $\left(L_{v}\right)$ e densidade de superfície $\left(S_{v}\right)$ (MANDARIM-DE-LACERDA, 2003) e devem ser sobrepostos às imagens obtidas dos campos microscópicos a serem estudados.

No presente estudo, dois campos microscópicos de cada uma das secções dos fragmentos tímicos foram escolhidos aleatoriamente. Destes, um campo foi obtido na região cortical e outro na junção corticomedular, perfazendo um total de dez campos por animal, cinco para cada região analisada. Assim, em cada grupo foram analisados 50 campos, 25 em cada uma das regiões estudadas. As imagens dos campos de análise foram obtidas com auxílio de um sistema de video- 
microscopia composto de uma câmera digital Kappa DS ${ }^{1}$ acoplada a um microscópio de luz Leica DMRBE$^{2}$ (objetiva de 40X) e interligada a um monitor Sony Trinitron ${ }^{3}$.

Para a quantificação vascular, necessária para as estimativas das variáveis estereológicas, foi utilizado um sistema-teste composto de dois sistemas sobrepostos (Figura 4), um sistema-teste de arcos ciclóides e uma área-teste.

O uso do sistema-teste de arcos ciclóides para a quantificação de estruturas em secções histológicas obtidas por cortes verticais foi inicialmente proposto por Baddeley, Gundersen e Cruz-Orive (1986) e aplicado neste estudo com base nestes e em outros autores que preconizam o método (MANDARIM-DE-LACERDA, 1994, 2003; MAKANYA; MAYHEW; MAINA, 1997; STEPIEN; OBARA, 2008).

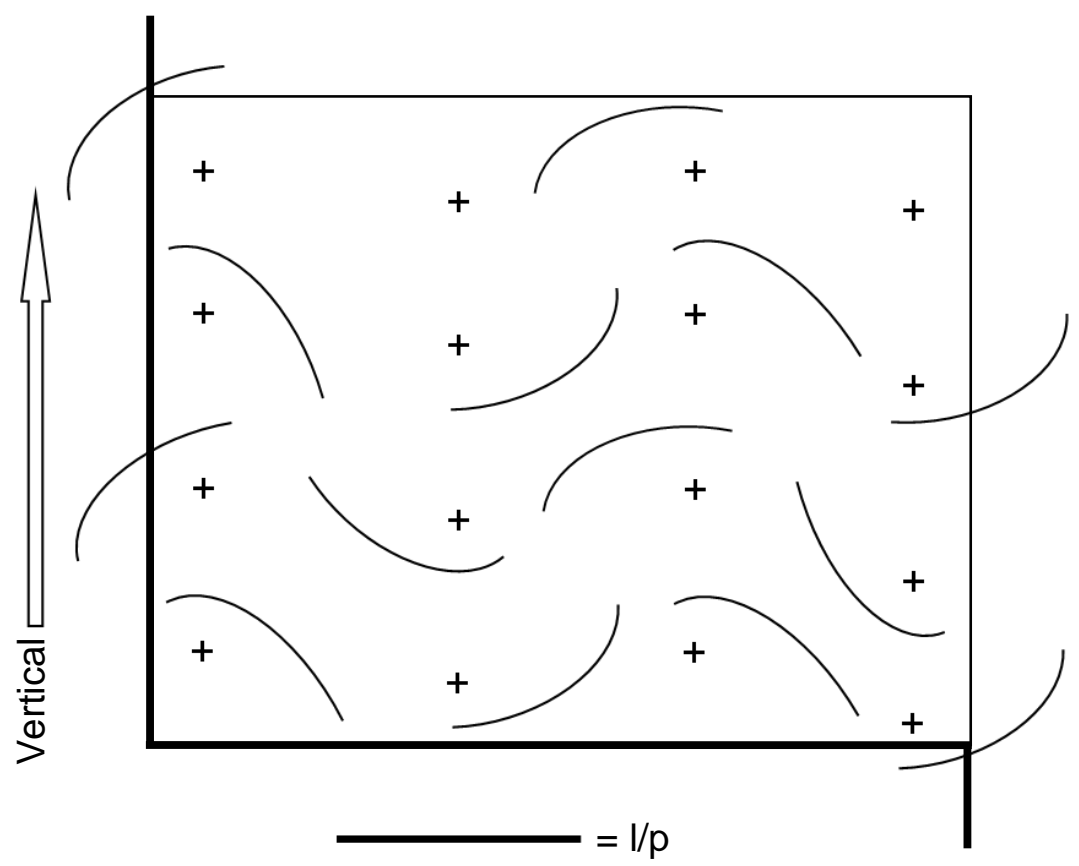

Figura 4 - Sistema-teste utilizado para a quantificação vascular do timo de suínos em idades pré e pós-natais. Dois sistemas foram sobrepostos e adaptados, um sistema-teste de arcos ciclóides (cruzes e arcos) e uma área-teste (linhas cheias e linhas finas). Cruzes são pontos-teste $(\mathrm{n}=16)$. O comprimento do arco ciclóide é definido como a linha $(\mathrm{l} / \mathrm{p})$. O sistema foi alinhado com as imagens das secções histológicas pela seta (lado esquerdo). Fonte: adaptado de Mandarim-de-Lacerda (2003)

\footnotetext{
${ }^{1}$ Kappa opto-electronics $\mathrm{GmbH}$, Gleichen, Germany

2 Leica Microsystems GmbH, Wetzlar, Germany

${ }^{3}$ Sony Corporation of America, CA, USA
} 
O sistema-teste utilizado (Figura 4) foi sobreposto à imagem histológica gerada no monitor do sistema de videoscopia previamente descrito e calibrado com auxílio de uma lâmina de calibragem micrométrica. Seu eixo menor foi alinhado paralelo ao eixo vertical do corte histológico. O sistema foi composto de 16 arcos

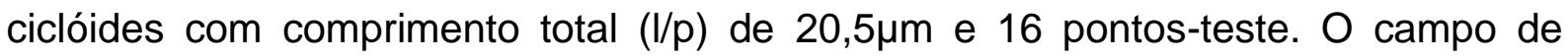
análise foi delimitado por uma área-teste $\left(\mathrm{A}_{T}\right)$ (Figura 4) medindo $12.100 \mu \mathrm{m}^{2} \mathrm{e}$ constituída por linhas de inclusão (margens superior e direita) e exclusão (margens inferior e esquerda). Apenas os perfis, ou seja, os vasos, que se localizaram dentro da área-teste e que não tocaram as linhas de exclusão foram contados. Com esse método as chances de amostragem de cada perfil são igualadas, independente do seu tamanho.

As variáveis estimadas por meio do sistema-teste empregado para a quantificação vascular neste estudo foram as seguintes: densidade de volume vascular do timo $\left(\mathrm{V}_{\mathrm{v}[\mathrm{vaso}, \text { timo] }}\right)$, densidade de superfície vascular do timo $\left(\mathrm{S}_{\mathrm{v}[\mathrm{vaso}, \mathrm{timo}]}\right)$ e densidade de comprimento vascular do timo ( $\left.L_{v[v a s o, t i m o]}\right)$.

\subsubsection{Densidade de Volume Vascular do Timo ( $\left.\mathrm{V}_{\mathrm{v}[\mathrm{vaso}, \text { timo }}\right)$}

A variável densidade de volume vascular do timo $\left(\mathrm{V}_{\mathrm{v}[\mathrm{vaso}, \mathrm{timo}]}\right)$ foi estimada na região cortical como densidade de volume vascular do córtex $\left(\mathrm{V}_{\mathrm{v}[\mathrm{c}]}\right)$ e na junção corticomedular como densidade de volume vascular da junção corticomedular $\left(\mathrm{V}_{\mathrm{v}[\mathrm{m}]}\right)$. Para tal, a fórmula utilizada foi:

$$
\mathbf{V}_{\mathbf{v}}=\mathbf{P}_{\mathbf{P}} / \mathbf{P}_{\mathbf{t}}
$$

Onde:

$\mathbf{P}_{\mathbf{p}}=$ número de pontos-teste que tocam vasos

$\mathbf{P}_{\mathbf{t}}=$ número total de pontos-teste contidos no sistema-teste (16) 


\subsubsection{Densidade de Superfície Vascular do Timo $\left(\mathrm{S}_{\mathrm{v}[\mathrm{vaso}, \mathrm{timo}]}\right)$}

Densidade de superfície avalia a relação entre a área e o volume de um componente pelo volume do espaço referência. Esta variável pode ser estimada pelo número de perfis que intersectam linhas de um sistema-teste (DOCKERY; FRAHER, 2007).

A área de superfície vascular é o produto do comprimento e da circunferência, importante para a descrição quantitativa dos vasos de um tecido (NYENGAARD; BENDTSEN; GUNDERSEN, 1988).

A variável densidade de superfície vascular do timo $\left(S_{v[v a s o, t i m o}\right)$ foi estimada na região cortical como densidade de superfície vascular do córtex $\left(S_{v[c]}\right)$ e na junção corticomedular como densidade de superfície vascular da junção corticomedular $\left(\mathrm{S}_{\mathrm{v}[\mathrm{m}]}\right)$. Para tal, a fórmula utilizada foi:

$$
\text { Sv }=2 \cdot I / L T
$$

Onde:

I = número de perfis que intersectam arcos ciclóides

$\mathbf{L}_{\mathbf{T}}=$ comprimento total do arco teste $(20,5 \mu \mathrm{m})$

\subsubsection{Densidade de Comprimento Vascular do Timo ( $\left.L_{v[v a s o, t i m o]}\right)$}

A variável densidade de comprimento vascular do timo ( $\left.L_{v[v a s o, t i m o}\right)$ foi estimada na região cortical como densidade de comprimento vascular do córtex $\left(L_{v[c]}\right)$ e na junção corticomedular como densidade de comprimento vascular da junção corticomedular $\left(\mathrm{L}_{v[\mathrm{~m}]}\right)$. Para tal, as fórmulas utilizadas foram: 


$$
L_{v}=2 Q_{A} \quad Q_{A}=N / A_{T}
$$

Onde:

$\mathbf{Q}_{\mathbf{A}}=$ densidade numérica por área

$\mathbf{N}$ = número de perfis dentro da área teste

$\mathbf{A}_{\mathbf{T}}=$ área teste $\left(12.100 \mu \mathrm{m}^{2}\right)$

\subsubsection{Análise Estatística}

As análises estatísticas foram realizadas com auxílio do programa GraphPad Prism $^{1}$ (versão 4.02). As diferenças para as variáveis estereológicas comparando o córtex e a junção corticomedular foram testadas nos animais do mesmo grupo pelo teste $t$ pareado. Para a comparação entre grupos usou-se a análise de variância (ANOVA) "one-way" e pós-teste de Tukey. Em todos os casos o nível de significância $\mathrm{p} \leq 0,05$ foi considerado como estatisticamente significativo.

\subsection{AVALIAÇÃO DA EXPRESSÃO DE mRNA}

Os procedimentos para o processamento do material para a avaliação da expressão gênica do VEGF e de seus receptores (Flt-1 e KRD) no timo dos animais de cada grupo experimental estão descritos nas subseções desta seção.

\footnotetext{
${ }^{1}$ GraphPad Software Inc., San Diego, CA, USA
} 


\subsubsection{Preparo das Amostras}

Amostras de $0,5 \mathrm{~cm}^{3}$ foram obtidas do lobo cervical direito do timo dos 5 fetos de cada grupo pré-natal e do lobo torácico dos 5 animais de cada grupo pós-natal. A escolha da região a ser amostrada do timo fetal se deu em virtude dos lobos cervicais representarem as maiores porções do órgão na espécie e a eleição do lobo cervical direito foi implantada apenas como método de padronização de coleta.

\subsubsection{Acondicionamento das Amostras para Extração do RNA Total}

As amostras foram acondicionadas em criotubos de $1,5 \mathrm{ml}$ e livres de RNase, para então serem imediatamente armazenadas em nitrogênio líquido e mantidas em um freezer à $-80^{\circ} \mathrm{C}$ até a realização do processamento para a extração de seu RNA.

\subsubsection{Extração de RNA Total pelo Método de Trizol}

Os tecidos acondicionados em criotubos foram pesados em gelo e acrescidos de $1000 \mu l$ de Trizol $^{\circledR 1}$. A trituração e homogeneização foram realizadas com o uso de pistilo apropriado para tubos Eppendorf ${ }^{2}$ de $1,5 \mathrm{ml}$. O homogenato foi centrifugado por 10 minutos a $12000 \mathrm{~g}$, à temperatura de $4^{\circ} \mathrm{C}$ e $\mathrm{o}$ pellet descartado. $\mathrm{O}$ sobrenadante foi incubado à temperatura ambiente durante 5 minutos. Após esse período, $200 \mu$ le clorofórmio foram adicionados e os tubos foram fechados e agitados vigorosamente por aproximadamente 15 segundos para então serem incubados novamente à temperatura ambiente por 2 a 3 minutos. As amostras foram centrifugadas por 15 minutos, a $12000 \mathrm{~g}$ e a $4^{\circ} \mathrm{C}$. Após a centrifugação, o sobrenadante foi transferido para tubos identificados e acrescidos de $500 \mu \mathrm{l}$ de

\footnotetext{
${ }^{1}$ Invitrogen ${ }^{\mathrm{TM}}$ Corporation, Carlsbad, CA, USA

2 Eppendorf A.G., Hamburg, Germany
} 
isopropanol, homogeneizados suave e manualmente e incubados à temperatura ambiente por 10 minutos. As amostras foram novamente centrifugadas por 10 minutos a $12000 \mathrm{~g}$ e a $4^{\circ} \mathrm{C}$. O sobrenadante foi descartado e o precipitado (RNA total) solubilizado com $1 \mathrm{ml}$ de álcool 75\% diluído em água tratada com dietil pirocarbonato (DEPC). Uma nova centrifugação foi realizada por 5 minutos, a $7500 \mathrm{~g}$ e a $4^{\circ} \mathrm{C}$. Retirou-se o excesso de álcool e o precipitado foi solubilizado em $20 \mu \mathrm{l}$ de água tratada com DEPC. Uma alíquota foi removida para quantificação, armazenando-se imediatamente o restante da solução em freezer a -80C.

\subsubsection{Quantificação do RNA Total}

Para a quantificação do RNA total as amostras foram diluídas na proporção 1:50, ou seja, $49 \mu l$ de água DEPC foi adicionada de $1 \mu$ do RNA total e homogeneizada suavemente. A quantificação foi realizada em aparelho biofotômetro (BioPhotometer plus ${ }^{1}$ ) a 260/280nm, em cubetas Eppendorf UVette ${ }^{\circledR 1}$. Água DEPC foi utilizada para a calibração do equipamento.

\subsubsection{Transcrição Reversa}

Na construção da fita de DNA complementar (cDNA), para assegurar que os resultados foram oriundos do mRNA e não do DNA genômico, as amostras foram previamente tratadas com $1 \mu$ de DNAse $^{2}$ em $1 \mu$ de tampão apropriado, fornecido pela mesma empresa, por 15 minutos a temperatura ambiente.

Aos tubos contendo RNA total ( $1 \mu \mathrm{g}$, previamente tratados com DNAse I), foram adicionados $1 \mu \mathrm{l}$ do Oligo $\mathrm{DT}^{1}$ e $1 \mu \mathrm{l}$ de $\mathrm{dNTPs}^{1}$ (mix $10 \mathrm{mM}-2,5 \mathrm{mM}$ de cada dNTP) para então serem incubados a $65^{\circ} \mathrm{C}$ por 5 minutos, retirados do termociclador e colocados em banho de gelo. Em seguida foram acrescentados aos tubos $4 \mu \mathrm{l}$ do

\footnotetext{
${ }^{1}$ Eppendorf A.G., Hamburg, Germany

${ }^{2}$ Invitrogen ${ }^{\mathrm{TM}}$ Corporation, Carlsbad, CA, USA
} 
tampão $5 X$ Superscript ${ }^{T M} I I I^{1}, 1 \mu \mathrm{l}$ de DTT $^{1} 1 \mathrm{M}$ e $1 \mu \mathrm{l}$ de RNAse OUT $^{1}$ e $1 \mu \mathrm{l}$ de água ultrapura autoclavada. Esta mistura foi incubada por 50 minutos a $37^{\circ} \mathrm{C}$ e em seguida por 15 minutos a $70^{\circ} \mathrm{C}$. O cDNA foi armazenado a $-20^{\circ} \mathrm{C}$ até o momento da amplificação do cDNA para o sistema VEGF por PCR em tempo real.

\subsubsection{PCR em Tempo Real}

Após a transcrição reversa (RT), foi efetuada a reação em cadeia da polimerase (PCR) em tempo real no aparelho ABI Prism ${ }^{\circledR} 7500^{1}$ e o sistema adotado para a detecção da expressão gênica do fator de crescimento VEGF e de seus receptores (Flt-1 e KDR) foi o sistema TaqMan ${ }^{\circledR 2}$.

\subsubsection{Primers}

Os primers utilizados nos testes de PCR em tempo real para VEGF, Flt-1, KDR e gliceraldeído fosfato desidrogenase (GAPDH) suíno estão os listados no Quadro 2.

\footnotetext{
${ }^{1}$ Applied Biosystems ${ }^{\mathrm{TM}}$ Inc., Carlsbad, CA, USA

${ }^{2}$ Applied Biosystems ${ }^{\text {TM }}$ Inc., Carlsbad, CA, USA
} 


\begin{tabular}{|c|c|}
\hline Gene & Primer \\
\hline \multirow[t]{3}{*}{ VEGF } & - TGTGCCCACTGAGGAGTTC \\
\hline & 4 TGGCCTTGGTGAGGTTTGATC \\
\hline & S: FAM-ATAATCTGCATGGCGATGTT \\
\hline \multirow[t]{3}{*}{ Flt-1 } & - CTGCTGCAAGCCAATGTACAA \\
\hline & $\triangleleft$ GCTCGTCAGAATGGCGTTGA \\
\hline & S: FAM-CAGGACGGCAAAGACTA \\
\hline \multirow[t]{3}{*}{ KDR } & - ACAAAACTGTCGTGATTCCATGTCT \\
\hline & $\varangle$ TCCCAGGAAATTCTGTTACCATCAG \\
\hline & S: FAM-CCTCTTTTCTGGATACCTCG \\
\hline \multirow[t]{3}{*}{ GAPDH } & - CGACCACTTCGTCAAGCTCATT \\
\hline & $\triangleleft$ ACCCTGTTGCTGTAGCCAAA \\
\hline & S: FAM-CCTGGTACGACAATGAA \\
\hline
\end{tabular}

\subsubsection{Condições da Reação de PCR em Tempo Real}

A amplificação dos cDNAs do VEGF e seus receptores no equipamento $A B I$ Prism ${ }^{\circledR} 7500^{1}$ seguiu os critérios determinados pelo fabricante do aparelho. Assim, a enzima uracil glicosilase (UNG), que corrige quaisquer problemas oriundos da transcrição reversa, foi ativada por 2 minutos a $50^{\circ} \mathrm{C}$ e desativada por 10 minutos a 95드. A reação em cadeia da polimerase propriamente dita ocorreu durante 40 ciclos, compreendendo 15 segundos a 95ำ para a desnaturação das fitas de cDNA, seguidos de 1 minuto a $60^{\circ} \mathrm{C}$ para extensão. Foi preparada uma mistura (mix) para cada gene estudado. Neste mix foram adicionados, por amostra a ser analisada, $6,25 \mu l$ de tampão Universal PCR Master $\operatorname{Mix}^{1}, 0,5 \mu l$ de primers senso, anti-senso

\footnotetext{
${ }^{1}$ Applied Biosystems ${ }^{\text {TM }}$ Inc., Carlsbad, CA, USA
} 
(concentração final de $900 \mathrm{mM}$ ) e sonda (concentração final de $250 \mathrm{mM}$ ) para os

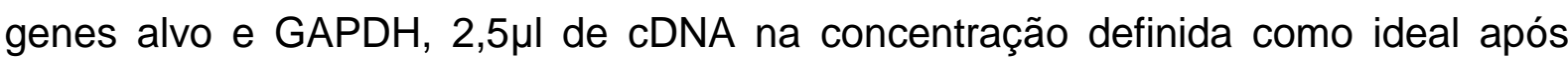
análise da curva de diluição (eficiência) para um volume final de $12,5 \mu$. Todas as amostras foram testadas em duplicata ou quadruplicata, quando necessário.

\subsubsection{Determinação da Eficiência dos Primers}

A eficiência dos primers foi testada para verificar se os pares de primers utilizados apresentavam eficiência próxima de $100 \%$, ou seja, se duplicavam o produto de PCR a cada ciclo de reação, condições consideradas ideais para avaliação da expressão relativa de um gene.

Uma curva padrão foi construída com as seguintes quantidades de cDNA: 0,5, $0,25,0,0625$ e 0,03125 $\mu \mathrm{g}$, utilizando os mesmos reagentes e concentrações acima descritos, o que gerou uma curva de amplificação da amostra em função de sua concentração. O cálculo da eficiência para os genes alvo e controle endógeno foi feito através do programa LinRegPCR (RAMAKERS et al., 2003). Para isso, considerou-se a eficiência média com base na curva de amplificação individual de cada amostra. A partir desta análise obtivemos os valores de ciclo de amplificação (Ct) nos quais a maioria das amostras alcançou a eficiência de amplificação ideal de $100 \%$.

A partir do resultado do Ct médio ideal, obteve-se um valor ideal de "threshold" que foi utilizado para determinar $0 \mathrm{Ct}$ individual das amostras amplificadas e então se realizar o cálculo da expressão relativa do mRNA dos genes de interesse. 


\subsubsection{Expressão Relativa do mRNA}

O cálculo da expressão relativa do mRNA foi efetuado a partir dos resultados obtidos no sistema de PCR em tempo real. No método comparativo para a expressão relativa de um gene alvo em comparação a um gene de referência, baseado na eficiência dos primers (PFAFFL, 2001), a quantidade do gene alvo é normalizada a um controle endógeno e calculada em relação a um calibrador utilizando-se a fórmula:

$$
\text { ratio }=\frac{(E \text { target })^{\wedge} \mathrm{CP} \text { target (control-sample) }}{\left(\text { E ref) }{ }^{\wedge} \mathrm{CP}\right. \text { ref (control-sample) }}
$$

Onde:

E target $=$ Eficiência do gene alvo

E ref $=$ Eficiência do gene constitutivo

${ }^{\wedge} \mathrm{CP}$ target $=$ Ct do controle menos a amostra do gene alvo transcrito

${ }^{\wedge} \mathrm{CP}$ ref $=\mathrm{Ct}$ do controle menos a amostra do gene construtivo transcrit

\subsubsection{Análise Estatística}

A expressão gênica do VEGF e dos receptores KDR e Flt-1 foi determinada como média \pm EPM de cinco replicatas de cada grupo experimental. $O$ efeito da idade dos animais foi avaliado utilizando-se os testes ANOVA e Kruskal-Wallis, de acordo com a distribuição e variância dos dados. Todos os testes foram realizados 
com o programa MINITAB ${ }^{\circledR}$ Statistical Software ${ }^{1}$ (versão 13 para Windows ${ }^{\circledR 2}$ ) e o nível de significância adotado foi $\mathrm{p}<0,05$.

\subsection{PROCESSAMENTO DO MATERIAL PARA IMUNO-HISTOQUÍMICA DO VEGF E SEUS RECEPTORES (Flt-1 E KDR)}

Amostras de $0,5 \mathrm{~cm}^{3}$, destinadas ao processamento para imuno-histoquímica do VEGF e seus receptores (Flt-1 e KDR), foram coletadas do lobo cervical esquerdo do timo dos animais de cada grupo pré-natal e de fragmentos dos lobos torácicos dos animais de cada grupo pós-natal.

\subsubsection{Fixação, Inclusão e Secção dos Tecidos}

As amostras foram fixadas em formol tamponado a 4\% por 24 horas. Posteriormente foram lavadas e armazenadas em solução salina tamponada com fosfato (PBS) até serem submetidas a protocolo padrão de inclusão Paraplast ${ }^{\circledR 1}$.

A desidratação foi realizada em uma série de etanol em concentrações crescentes (70\%, 90\%, absoluto I, II e III, uma hora cada) e a diafanização em xilol (xilol I, II e III, uma hora cada). A inclusão em Paraplast ${ }^{\circledR}$ Plus $^{3}$ (I, II e de inclusão, 1 hora cada) foi realizada sob procedimentos convencionais.

Secções de $4 \mu \mathrm{m}$ foram preparadas em micrótomo e dispostas em lâminas silanizadas antes de serem submetidas à imuno-histoquímica.

\footnotetext{
${ }^{1}$ Minitab Inc., TX, USA

${ }^{2}$ Microsoft Corporation, USA

${ }^{3}$ McCormick Scientific LLC, Maryland Heights, MO, USA
} 


\subsubsection{Imuno-histoquímica do VEGF e seus Receptores (FIt-1 e KDR)}

As secções dispostas em lâminas previamente silanizadas (tratamento com APTES descrito na página 63) foram desparafinizadas em xilol ( 2 x 10 minutos), reidratadas em uma série de etanol com concentrações decrescentes (absoluto I e II, 95\%, 70\% e 50\%, 5 minutos cada) e lavadas em água destilada ( 1 x 5 minutos). Posteriormente as lâminas foram imersas em tampão citrato à temperatura ambiente ( $1 \times 5$ minutos) e, em seguida, receberam tratamento com microondas $(3 \times 5$ minutos) em potência máxima, imersas na mesma solução, para melhor exposição dos antígenos. Após 20 minutos de resfriamento em tampão citrato e à temperatura ambiente, procedeu-se a lavagem das lâminas com água destilada ( $2 \times 2$ minutos) em agitação e solução salina tamponada com fosfato (PBS) $(0,15 \mathrm{M} ; \mathrm{pH} 7,2)(1 \times 5$ minutos) em agitação. Em seguida, a atividade da peroxidase endógena foi bloqueada durante 10 minutos com solução de peroxidase hidrogenada a $3 \%$ (Peroxidase Block ${ }^{1}$ ) e, posteriormente, as lâminas foram lavadas em PBS (3 x 5 minutos) em agitação. Para reduzir as ligações inespecíficas, as secções foram incubadas durante 20 minutos em solução para bloqueio de proteínas (Protein Block $^{2}$ ). Após este procedimento, as secções foram incubadas com anticorpo primário (anti-corpo policlonal anti-VEGF/sc $152^{3}$, anti-Flt-1/sc $316^{3}$ e anti-KDR/sc $\left.315^{3}\right)$, por 20 horas a $4^{\circ} \mathrm{C}$. Depois de lavagens em PBS ( 3 x 5 minutos) em agitação, procedeu-se a incubação com anticorpo secundário anti-coelho, camundongo e carneiro (Biotinylated Link ${ }^{1}$ ) por 15 minutos à temperatura ambiente e, após novas lavagens em PBS (3 x 5 minutos em agitação), as secções foram incubadas com solução amplificadora de estreptavidina conjugada com peroxidase de rábano em PBS (Streptavidin-HRP ${ }^{1}$ ) por 15 minutos a temperatura ambiente para amplificação do sinal da reação. Lavou-se novamente as lâminas em PBS ( $3 \times 5$ minutos) em agitação e procedeu-se a revelação da reação de imuno-histoquímica específica utilizando-se solução de diaminobenzidina (DAB Chromogen + Substrate Buffer ${ }^{4}$ ) por 5 minutos. Finalmente, as secções foram lavadas em água destilada $(2 \times 10$

\footnotetext{
${ }^{1}$ LSAB+System-HRP, Dako, Glostrup, Danmark

2 Dako, Glostrup, Danmark

${ }^{3}$ Santa Cruz Biotechnology ${ }^{\circledR}$ Inc., Santa Cruz, CA, USA

${ }^{4}$ LSAB+System-HRP, Dako, Glostrup, Danmark
} 
minutos) em agitação e contra-coradas com hematoxilina de Harris por 3 minutos. As lâminas foram lavadas em água corrente por 10 minutos e submetidas a protocolo de desidratação (álcool 70\%, álcool 95\%, álcool absoluto I, álcool absoluto II, xilol I e xilol II - 1 x 2 minutos cada).

A montagem das lâminas sob lamínula foi realizada com resina sintética dissolvida em tolueno (Permount ${ }^{\mathrm{TM} 1}$ ). Como controles negativos foram utilizados cortes incubados com PBS em substituição ao anticorpo primário. Os controles positivos foram feitos utilizando-se tecido placentário de suínos com comprovada marcação para os anticorpos utilizados (WINTHER et al., 1999).

As lâminas foram visualizadas em microscópio Nikon Eclipse E-800² equipado com câmera de vídeo CoolSNAP-Pro of $\operatorname{Color}^{\circledR 3}$ e as imagens foram capturadas através do software Image-Pro ${ }^{\circledR}$ Plus $^{4}$ (versão 6.0).

\footnotetext{
${ }^{1}$ Fisher Scientific, Morris Plains, NJ, USA

${ }^{2}$ Nikon Instruments Inc., Melville, NY, USA

${ }^{3}$ Media Cybernetics Inc., Bethesda, MD, USA
} 
RESULTADOS 


\section{RESULTADOS}

Neste capítulo os resultados estão apresentados em seções, de acordo com a metodologia utilizada no presente estudo. Porém, a última seção foi reservada para a apresentação de uma correlação entre os resultados obtidos na estereologia e os resultados da análise, por PCR em tempo real, da expressão relativa do mRNA do VEGF e seus receptores (FIt-1 e KDR).

\subsection{ESTEREOLOGIA}

As variáveis estereológicas foram estimadas no córtex e na JCM do timo dos animais de todos os grupos experimentais. Os resultados obtidos em cada região avaliada estão descritos nas próximas subseções desta seção.

Os valores individuais da quantificação de perfis por campo microscópico, assim como os valores individuais calculados para as variáveis $\mathrm{V}_{\mathrm{v}[\mathrm{c}]}, \mathrm{V}_{\mathrm{v}[\mathrm{m}]}, \mathrm{S}_{\mathrm{v}[\mathrm{c}]}, \mathrm{S}_{\mathrm{v}[\mathrm{m}]}$, $L_{v[c]}$ e $L_{v[m]}$, em cada grupo experimental, estão dispostos nas Tabelas 1, 2, 3, 4 e 5.

Os valores das variáveis de cada região foram comparados entre grupos (Tabelas 7 e 8), assim como os valores das variáveis estimadas no córtex foram comparados aos valores das variáveis estimadas na JCM de cada grupo (Tabela 9).

Fotomicrografias da imunomarcação dos vasos sanguíneos tímicos com anticorpo policlonal anti-laminina estão demonstradas na Figura 5. 

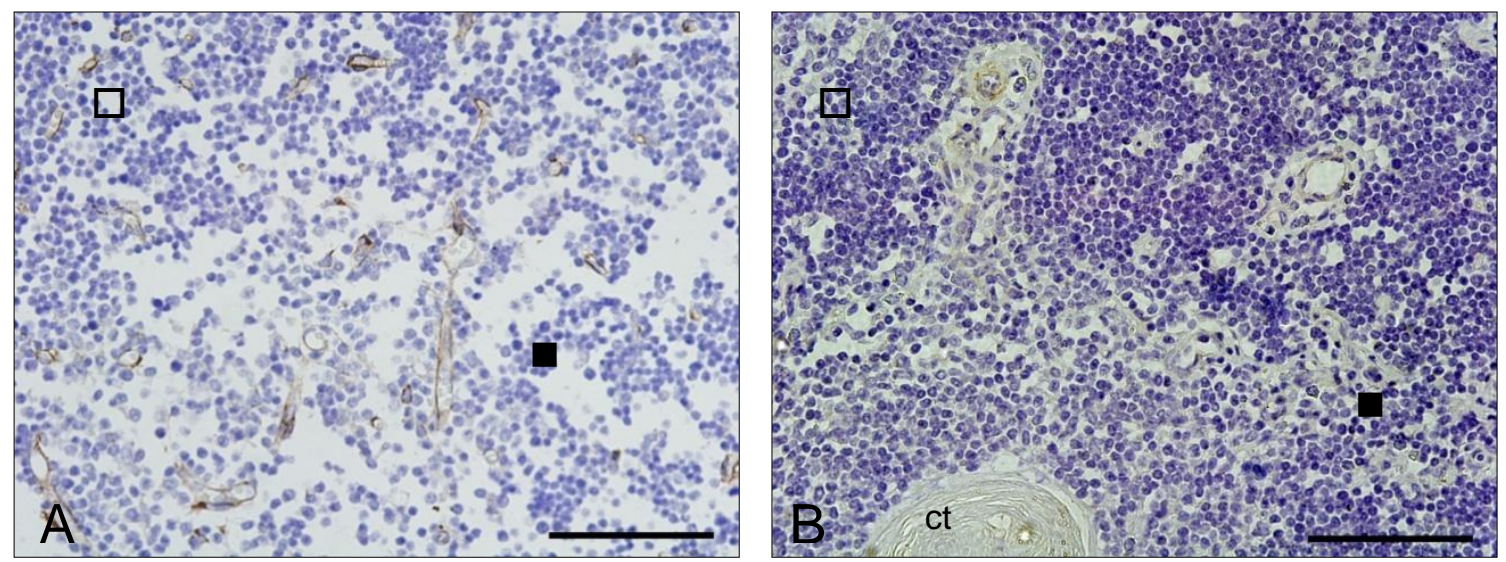

Figura 5 (A-B) - Fotomicrografias da junção corticomedular ( $\mathbf{\square})$ e camada cortical interna ( $\square$ ) do timo de suínos. Reação imuno-histoquímica realizada com anticorpo policlonal anti-laminina (BioGenex PU078-UP) diluído 1:50 e contracoloração com hematoxilina. A) Timo de feto suíno de 111 dias de idade gestacional. B) Timo de suíno adulto com 2 anos de idade. Legenda: ct, corpúsculo tímico. Notar a grande concentração de capilares sanguíneos na camada cortical interna, bem como de vasos na junção corticomedular de A em relação a B. Barras: $100 \mu m$

\subsubsection{Densidade de Volume Vascular do Timo ( $\left.\mathrm{V}_{\mathrm{v}[\mathrm{vaso}, \mathrm{timo}]}\right)$}

A variável $\mathrm{V}_{\mathrm{v}[\mathrm{c}]}$ manteve-se constante ao longo do desenvolvimento fetal $\mathrm{e}$ apresentou queda significativa no período pós-natal (Gráfico 1). Diferença estatisticamente significativa foi observada entre os animais de 5 meses de idade e os animais de $65(\mathrm{p}=0,002)$ e $85(\mathrm{p}=0,02)$ dias, bem como entre os animais de 2 anos de idade e os animais de $65(p=0,0004), 85(p=0,003)$ e $111(p=0,03)$ dias. A variável $\mathrm{V}_{\mathrm{v}[\mathrm{c}]}$ apresentou valores entre 5 e 7,5\% nos grupos pré-natais e diminuiu no timo dos animais de 5 meses e 2 anos de idade, caindo para valores entre 2 e $3 \%$. A variável $\mathrm{V}_{\mathrm{v}[\mathrm{m}]}$ se apresentou constante entre 65 e 85 dias de gestação e aumentou significativamente no final da gestação, aos 111 dias. Nas fases pós-natais houve uma queda acentuada em relação ao final da gestação. Diferença estatisticamente significativa foi detectada entre os animais de 111 dias e os animais dos demais grupos pré-natais: 65 dias $(p=0,0003)$ e 85 dias $(p=0,002)$, como também entre os animais dos grupos pós-natais: 5 meses $(p=0,004)$ e 2 anos $(p=0,008)$. Os valores partiram de $4 \%$ aos 65 dias, passaram por $6 \%$ aos 85 dias e chegaram a $14 \%$ aos 
111 dias de gestação; aos 5 meses decaíram para 7\% se mantendo constante aos 2 anos de idade.

Quando comparadas as variáveis $\mathrm{V}_{\mathrm{v}[\mathrm{c}]}$ e $\mathrm{V}_{\mathrm{v}[\mathrm{m}]}$, diferenças significativas foram observadas em todos os grupos estudados, exceto no timo dos animais de 85 dias de idade gestacional, nos quais foi detectado um equilíbrio entre estas variáveis.

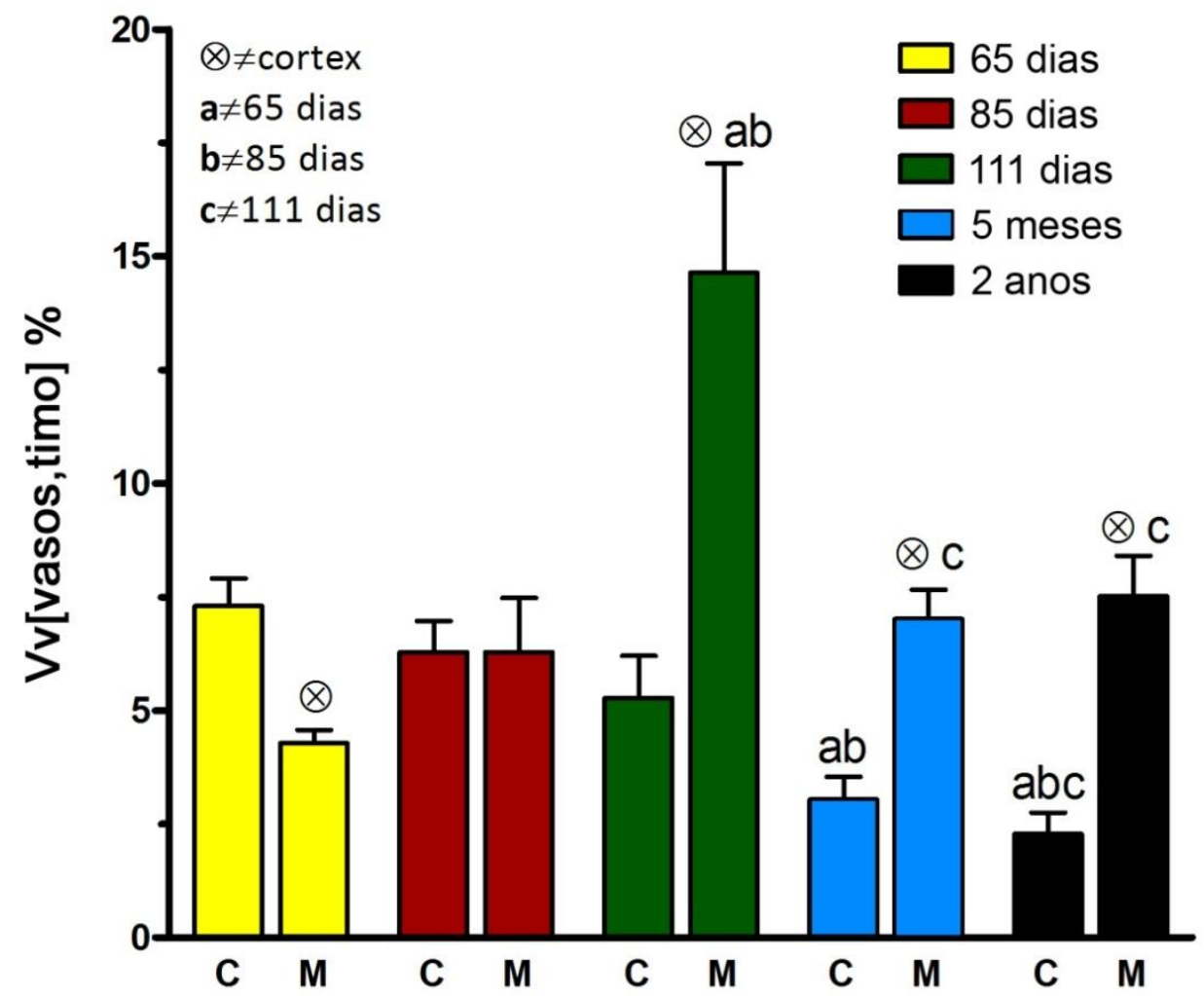

Gráfico 1 - Densidade de volume vascular $\left(\mathrm{V}_{\mathrm{v}[\mathrm{vasos}, \text { timo] }}\right)$ no córtex (C) e junção corticomedular (M) do timo suíno nos grupos experimentais pré e pós-natais. Legenda: $\otimes$, diferença significativa entre $\mathrm{C}$ e $\mathrm{M}$ (t pareado, $\mathrm{p} \leq 0,05)$; letras $(\mathbf{a} ; \mathbf{b} ; \mathbf{c})$, diferenças significativas entre grupos na mesma região do timo ao longo do desenvolvimento e involução do órgão (ANOVA one way e pós-teste de Tukey, $\mathrm{p} \leq 0,05$ ) 


\subsubsection{Densidade de Superfície Vascular do Timo $\left(\mathrm{S}_{\mathrm{v}[\mathrm{vaso}, \mathrm{timo}]}\right)$}

A variável densidade $S_{v[c]}$ se manteve constante (valores de 37 a $43 \mathrm{~mm}^{2} / \mathrm{mm}^{3}$ ) entre os fetos com idades gestacionais de 65 e 85 dias e apresentou tendência $(p=0,05)$ a decréscimo ao final da gestação (valor de $30 \mathrm{~mm}^{2} / \mathrm{mm}^{3}$ ) (Gráfico 2). Houve uma diminuição significativa após o nascimento e os valores caíram para $14 \mathrm{~mm}^{2} / \mathrm{mm}^{3}$ aos 5 meses e $7 \mathrm{~mm}^{2} / \mathrm{mm}^{3}$ aos 2 anos de idade. A variável $\mathrm{S}_{\mathrm{v}[\mathrm{m}]}$ se apresentou constante entre 65 e 85 dias de gestação, com tendência a aumento entre 85 e 111 dias. Quando comparados o final (111 dias) e o terço médio da gestação (65 dias) a variável $S_{v[m]}$ apresentou aumento significativo $(p=0,02)$. Após o nascimento, os animais de 5 meses não apresentaram alteração nos valores de $S_{v[m]}$, mas os animais adultos de 2 anos de idade apresentaram diminuição $(p=0,03)$ em relação ao final da gestação, aos 111 dias.

A variável $S_{v[c]}$ apresentou diferenças estatisticamente significativas $(p \leq 0,05)$ quando comparada à variável $S_{\mathrm{v}[\mathrm{m}]}$ do timo dos animais dos cinco grupos estudados, exceto no grupo pré-natal de 111 dias de idade gestacional. 


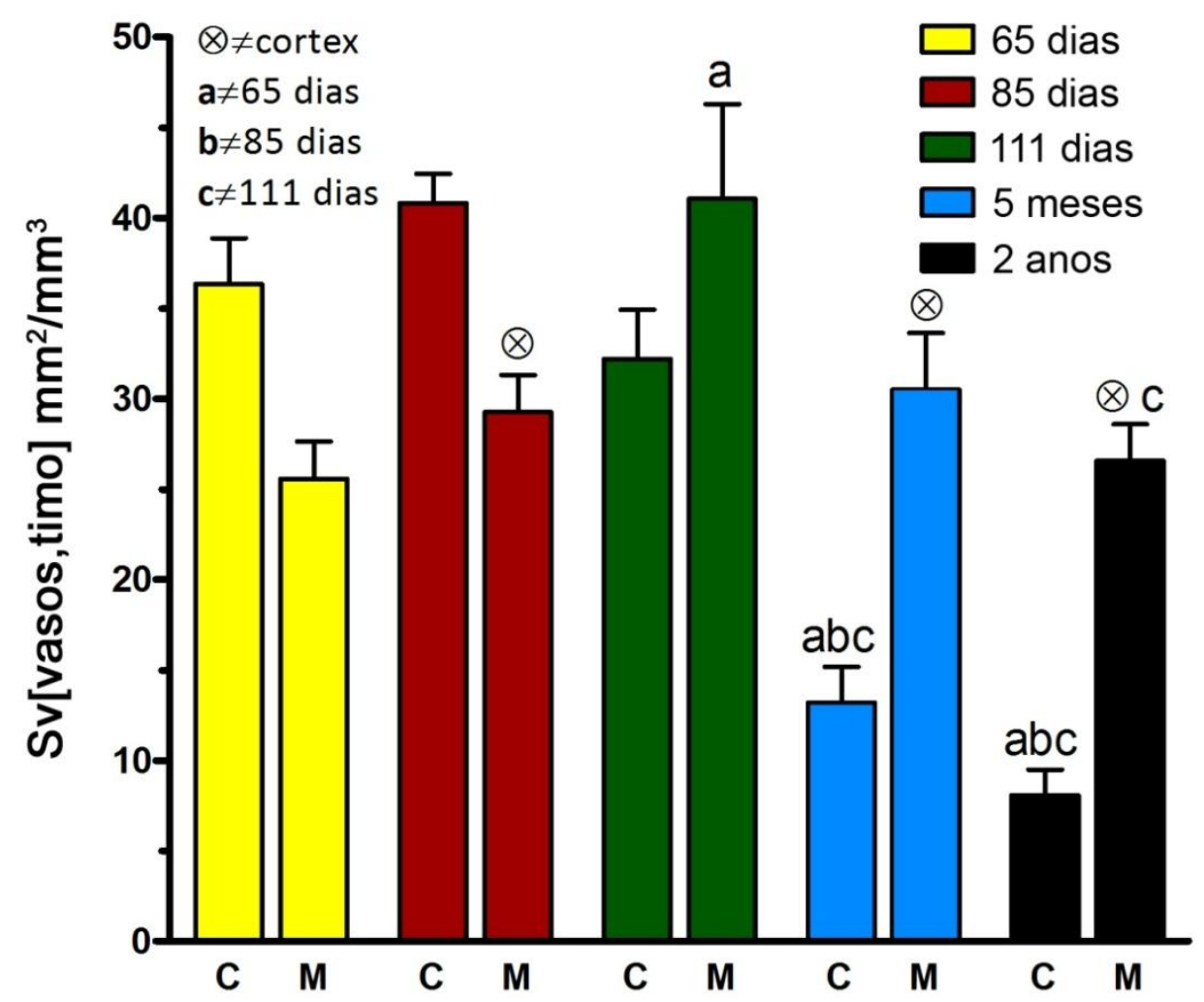

Gráfico 2 - Densidade de superfície vascular $\left(S_{\text {v[vasos,timo] }}\right)$ no córtex (C) e junção corticomedular (M) do timo suíno nos grupos experimentais pré e pós-natais. Legenda: $\otimes$, diferença significativa entre C e M (t pareado, $p \leq 0,05)$; letras $(\mathbf{a} ; \mathbf{b} ; \mathbf{c})$, diferenças significativas entre grupos na mesma região do timo ao longo do desenvolvimento e involução do órgão (ANOVA one way e pós-teste de Tukey, $\mathrm{p} \leq 0,05)$

\subsubsection{Densidade de Comprimento Vascular do Timo ( $\left.\mathrm{L}_{\mathrm{v}[\mathrm{vaso}, \mathrm{timo}]}\right)$}

A variável $L_{v[c]}$ se apresentou constante (valores entre 350 e $420 \mathrm{~mm} / \mathrm{mm}^{3}$ ) entre os grupos pré-natais e diminuiu com diferença estatisticamente significativa $(\mathrm{p}=0,0001)$ nos grupos pós-natais (valores entre 180 e $220 \mathrm{~mm} / \mathrm{mm}^{3}$ ) (Gráfico 3). Já a variável $L_{v[m]}$ foi constante entre todos os grupos pré e pós-natais (valores entre 350 e $425 \mathrm{~mm} / \mathrm{mm}^{3}$ ). Quando comparadas as variáveis $L_{v[c]}$ e $L_{v[\mathrm{~m}]}$ de um mesmo grupo experimental, em todos os grupos de idades pré e pós-natais houve diferença estatisticamente significativa, porém, como já sugerido pelos dados supracitados, nas fases pré-natais a variável $L_{v[c]}$ apresentou valores superiores à variável $L_{v[m]}$, 
enquanto que após o nascimento essa relação se inverteu, com valores de $L_{v[c]}$ inferiores aos de $L_{v[m]}$.

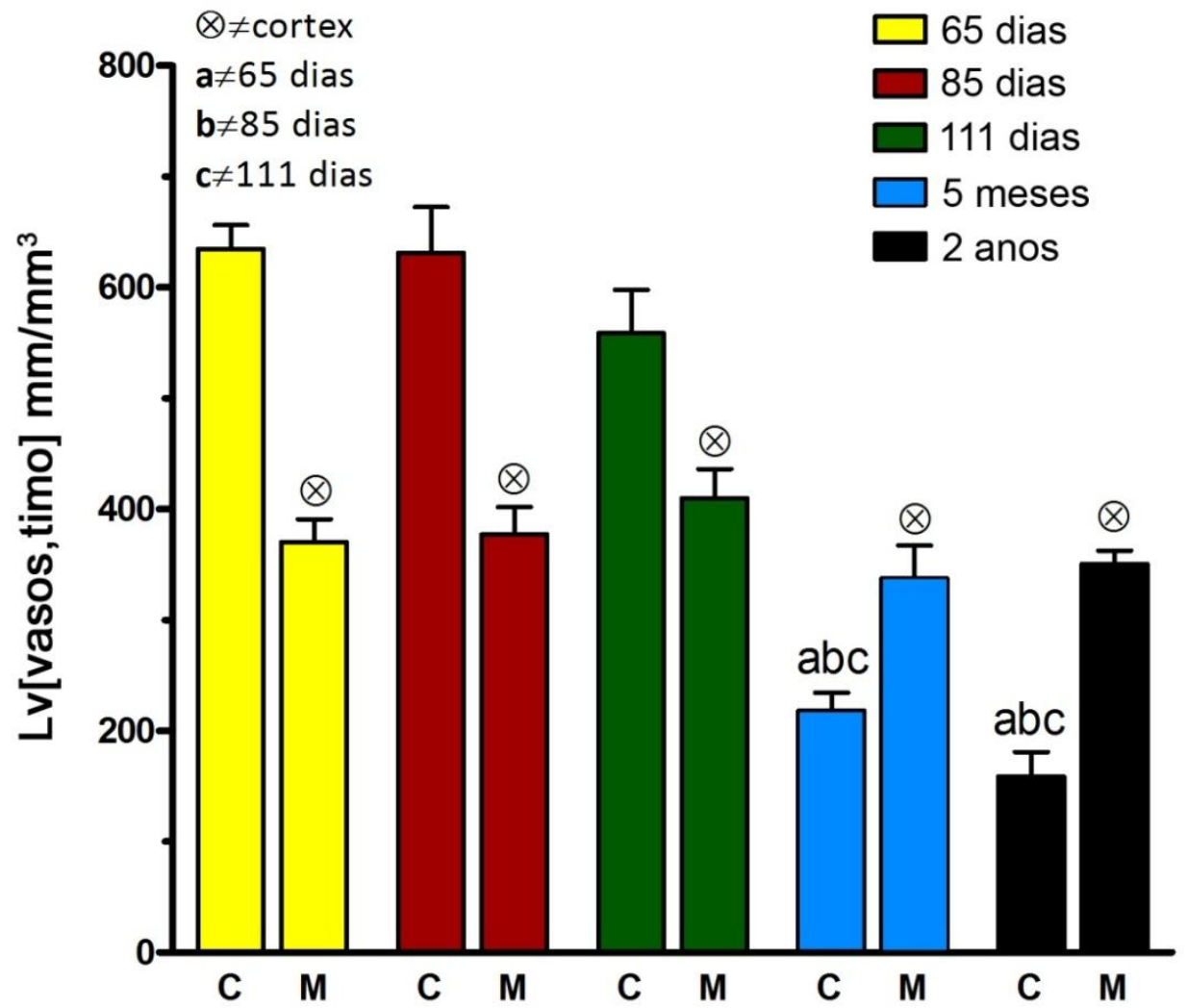

Gráfico 3 - Densidade de comprimento vascular $\left(\mathrm{L}_{\mathrm{v}[\mathrm{vasos}, \mathrm{timo}]}\right)$ no córtex $(\mathrm{C})$ e junção corticomedular (M) do timo suíno nos grupos experimentais pré e pós-natais. Legenda: $\otimes$, diferença significativa entre C e M (t pareado, $p \leq 0,05)$; letras $(\mathbf{a} ; \mathbf{b} ; \mathbf{c})$, diferenças significativas entre grupos na mesma região do timo ao longo do desenvolvimento e involução do órgão (ANOVA one way e pós-teste de Tukey, $\mathrm{p} \leq 0,05$ ) 
Tabela 1 - Perfis por campo e valores das variáveis estereológicas calculados para o córtex e junção corticomedular do timo de cada animal do grupo I

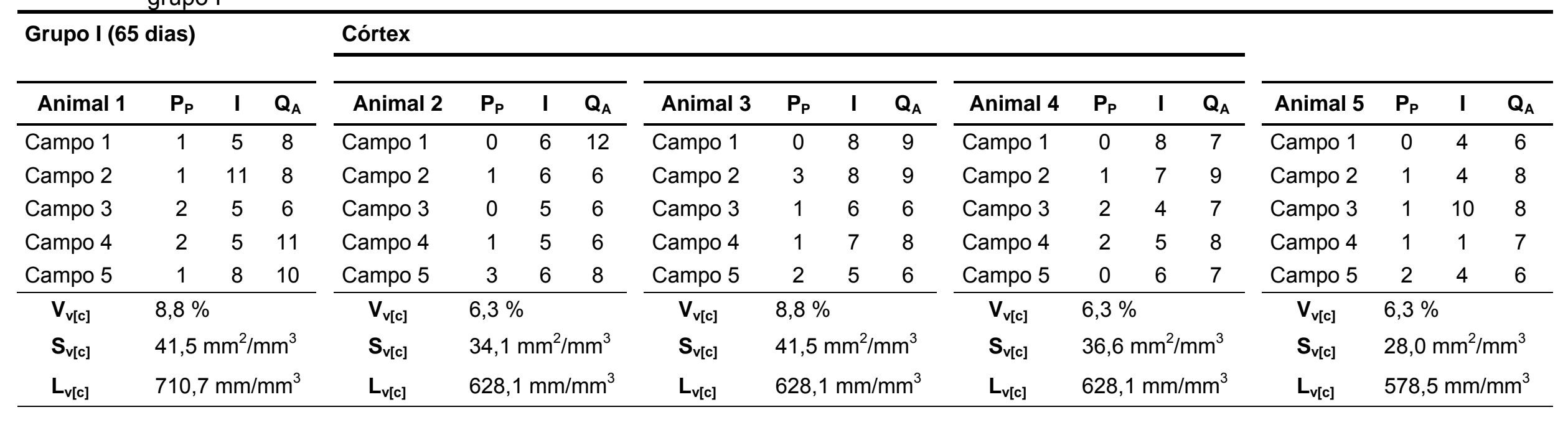

\section{Junção Corticomedular}

\begin{tabular}{|c|c|c|c|c|c|c|c|c|c|c|c|c|c|c|c|c|c|c|c|}
\hline Animal 1 & $\mathbf{P}_{\mathbf{P}}$ & I & $\mathbf{Q}_{\mathbf{A}}$ & Animal 2 & $\mathbf{P}_{\mathbf{P}}$ & I & $\mathbf{Q}_{\mathbf{A}}$ & Animal 3 & $\mathbf{P}_{\mathbf{P}}$ & I & $\mathbf{Q}_{\mathbf{A}}$ & Animal 4 & $\mathbf{P}_{\mathbf{P}}$ & I & $\mathbf{Q}_{\mathbf{A}}$ & Animal 5 & $\mathbf{P}_{\mathbf{P}}$ & I & $\mathbf{Q}_{\mathrm{A}}$ \\
\hline Campo 1 & 1 & 5 & 4 & Campo 1 & 1 & 2 & 3 & Campo 1 & 0 & 1 & 5 & Campo 1 & 2 & 2 & 7 & Campo 1 & 1 & 7 & 7 \\
\hline Campo 2 & 0 & 1 & 5 & Campo 2 & 1 & 7 & 4 & Campo 2 & 1 & 5 & 3 & Campo 2 & 1 & 7 & 3 & Campo 2 & 1 & 5 & 5 \\
\hline Campo 3 & 1 & 4 & 5 & Campo 3 & 0 & 5 & 2 & Campo 3 & 1 & 4 & 5 & Campo 3 & 0 & 6 & 4 & Campo 3 & 1 & 3 & 5 \\
\hline Campo 4 & 0 & 2 & 4 & Campo 4 & 0 & 3 & 5 & Campo 4 & 1 & 4 & 4 & Campo 4 & 0 & 4 & 5 & Campo 4 & 0 & 5 & 4 \\
\hline Campo 5 & 1 & 5 & 5 & Campo 5 & 1 & 8 & 6 & Campo 5 & 0 & 1 & 5 & Campo 5 & 1 & 4 & 6 & Campo 5 & 0 & 3 & 4 \\
\hline $\mathbf{V}_{\mathrm{v}[\mathrm{m}]}$ & $3,8 \%$ & & & $\mathbf{V}_{\mathrm{v}[\mathrm{m}]}$ & $3,8 \%$ & & & $\mathbf{V}_{\mathrm{v}[\mathrm{m}]}$ & $5,0 \%$ & & & $V_{v[m]}$ & $5,0 \%$ & & & $V_{v[m]}$ & $3,8 \%$ & & \\
\hline $\mathrm{S}_{\mathrm{v}[\mathrm{m}]}$ & \multicolumn{3}{|c|}{$20,7 \mathrm{~mm}^{2} / \mathrm{mm}^{3}$} & $\mathrm{~S}_{\mathrm{v}[\mathrm{m}]}$ & \multicolumn{3}{|c|}{$30,5 \mathrm{~mm}^{2} / \mathrm{mm}^{3}$} & $\mathrm{~S}_{\mathrm{v}[\mathrm{m}]}$ & \multicolumn{3}{|c|}{$20,7 \mathrm{~mm}^{2} / \mathrm{mm}^{3}$} & $\mathrm{~S}_{\mathrm{v}[\mathrm{m}]}$ & \multicolumn{3}{|c|}{$28,0 \mathrm{~mm}^{2} / \mathrm{mm}^{3}$} & $\mathrm{~S}_{\mathrm{v}[\mathrm{m}]}$ & \multicolumn{3}{|c|}{$28,0 \mathrm{~mm}^{2} / \mathrm{mm}^{3}$} \\
\hline $\mathbf{L}_{v[\mathrm{~m}]}$ & \multicolumn{3}{|c|}{$380,2 \mathrm{~mm} / \mathrm{mm}^{3}$} & $\mathbf{L}_{\mathrm{v}[\mathrm{m}]}$ & \multicolumn{3}{|c|}{$330,6 \mathrm{~mm} / \mathrm{mm}^{3}$} & $\mathbf{L}_{\mathrm{v}[\mathrm{m}]}$ & \multicolumn{3}{|c|}{$314,0 \mathrm{~mm} / \mathrm{mm}^{3}$} & $\mathbf{L}_{v[\mathrm{~m}]}$ & \multicolumn{3}{|c|}{$413,2 \mathrm{~mm} / \mathrm{mm}^{3}$} & $\mathbf{L}_{\mathrm{v}[\mathrm{m}]}$ & \multicolumn{3}{|c|}{$413,2 \mathrm{~mm} / \mathrm{mm}^{3}$} \\
\hline
\end{tabular}

$\mathbf{P}_{\mathbf{p}}=$ número de pontos-teste que tocam vasos; $\mathbf{Q}_{\mathbf{A}}=$ número de perfis por área; $\mathbf{I}=$ número de intersecções vasculares com arcos ciclóides 
Tabela 2 - Perfis por campo e valores das variáveis estereológicas calculados para o córtex e junção corticomedular do timo de cada animal do grupo II

\begin{tabular}{|c|c|c|c|c|c|c|c|c|c|c|c|c|c|c|c|c|c|c|c|}
\hline \multicolumn{4}{|c|}{ Grupo II (85 dias) } & \multicolumn{12}{|l|}{ Córtex } & Animal 5 & $\mathbf{P}_{\mathbf{P}}$ & $\mathbf{I}$ & $\mathbf{Q}_{\mathrm{A}}$ \\
\hline Campo 1 & 1 & 11 & 12 & Campo 1 & 1 & 6 & 5 & Campo 1 & 1 & 9 & 8 & Campo 1 & 2 & 4 & 6 & Campo 1 & 0 & 4 & 9 \\
\hline Campo 3 & 0 & 5 & 8 & Campo 3 & 1 & 5 & 8 & Campo 3 & 1 & 8 & 7 & Campo 3 & 1 & 3 & 9 & Campo 3 & 0 & 5 & 5 \\
\hline Campo 4 & 2 & 7 & 9 & Campo 4 & 1 & 11 & 9 & Campo 4 & 0 & 5 & 8 & Campo 4 & 3 & 4 & 7 & Campo 4 & 3 & 7 & 7 \\
\hline$S_{\mathrm{v}[c]}$ & \multicolumn{3}{|c|}{$45,1 \mathrm{~mm}^{2} / \mathrm{mm}^{3}$} & $\mathrm{~S}_{\mathrm{v}[\mathrm{c}]}$ & \multicolumn{3}{|c|}{$41,5 \mathrm{~mm}^{2} / \mathrm{mm}^{3}$} & $\mathrm{~S}_{\mathrm{v}[\mathrm{c}]}$ & \multicolumn{3}{|c|}{$42,7 \mathrm{~mm}^{2} / \mathrm{mm}^{3}$} & $\mathrm{~S}_{\mathrm{v}[\mathrm{c}]}$ & \multicolumn{3}{|c|}{$29,3 \mathrm{~mm}^{2} / \mathrm{mm}^{3}$} & $\mathrm{~S}_{\mathrm{v}[\mathrm{c}]}$ & \multicolumn{3}{|c|}{$35,4 \mathrm{~mm}^{2} / \mathrm{mm}^{3}$} \\
\hline $\mathrm{L}_{\mathrm{v}[\mathrm{c}]}$ & \multicolumn{3}{|c|}{$793,4 \mathrm{~mm} / \mathrm{mm}^{3}$} & $\mathrm{~L}_{\mathrm{v}[\mathrm{c}]}$ & \multicolumn{3}{|c|}{$578,5 \mathrm{~mm} / \mathrm{mm}^{3}$} & $\mathrm{~L}_{\mathrm{v}[\mathrm{c}]}$ & \multicolumn{3}{|c|}{$595,0 \mathrm{~mm} / \mathrm{mm}^{3}$} & $\mathrm{~L}_{\mathrm{v}[\mathrm{c}]}$ & \multicolumn{3}{|c|}{$611,6 \mathrm{~mm} / \mathrm{mm}^{3}$} & $\mathrm{~L}_{\mathrm{v}[\mathrm{c}]}$ & \multicolumn{3}{|c|}{$578,5 \mathrm{~mm} / \mathrm{mm}^{3}$} \\
\hline
\end{tabular}

\section{Junção Corticomedular}

\begin{tabular}{|c|c|c|c|c|c|c|c|c|c|c|c|c|c|c|c|c|c|c|c|}
\hline Animal 1 & $\mathbf{P}_{\mathbf{P}}$ & I & $\mathbf{Q}_{\mathbf{A}}$ & Animal 2 & $\mathbf{P}_{\mathbf{P}}$ & I & $\mathbf{Q}_{\mathbf{A}}$ & Animal 3 & $\mathbf{P}_{\mathbf{P}}$ & I & $\mathbf{Q}_{\mathrm{A}}$ & Animal 4 & $\mathbf{P}_{\mathbf{P}}$ & I & $\mathbf{Q}_{\mathbf{A}}$ & Animal 5 & $\mathbf{P}_{\mathbf{P}}$ & I & $\mathbf{Q}_{\mathbf{A}}$ \\
\hline Campo 1 & 1 & 5 & 5 & Campo 1 & 1 & 4 & 4 & Campo 1 & 2 & 6 & 4 & Campo 1 & 1 & 6 & 6 & Campo 1 & 2 & 6 & 5 \\
\hline Campo 2 & 0 & 7 & 5 & Campo 2 & 1 & 5 & 3 & Campo 2 & 3 & 4 & 7 & Campo 2 & 0 & 4 & 5 & Campo 2 & 1 & 3 & 7 \\
\hline Campo 3 & 0 & 8 & 6 & Campo 3 & 0 & 2 & 3 & Campo 3 & 1 & 5 & 4 & Campo 3 & 1 & 6 & 5 & Campo 3 & 0 & 7 & 4 \\
\hline Campo 4 & 1 & 6 & 4 & Campo 4 & 2 & 5 & 4 & Campo 4 & 1 & 4 & 7 & Campo 4 & 0 & 6 & 3 & Campo 4 & 2 & 3 & 3 \\
\hline Campo 5 & 0 & 3 & 4 & Campo 5 & 3 & 3 & 3 & Campo 5 & 0 & 4 & 4 & Campo 5 & 2 & 4 & 4 & Campo 5 & 0 & 4 & 5 \\
\hline $\mathbf{V}_{\mathrm{v}[\mathrm{m}]}$ & \multicolumn{3}{|c|}{$2,5 \%$} & $V_{v[m]}$ & \multicolumn{3}{|c|}{$8,8 \%$} & $\mathbf{V}_{\mathrm{v}[\mathrm{m}]}$ & \multicolumn{3}{|c|}{$8,8 \%$} & $\mathbf{V}_{\mathrm{v}[\mathrm{m}]}$ & \multicolumn{3}{|c|}{$5,0 \%$} & $\mathrm{~V}_{\mathrm{v}[\mathrm{m}]}$ & \multicolumn{3}{|c|}{$6,3 \%$} \\
\hline $\mathrm{S}_{\mathrm{v}[\mathrm{m}]}$ & \multicolumn{3}{|c|}{$35,4 \mathrm{~mm}^{2} / \mathrm{mm}^{3}$} & $\mathrm{~S}_{\mathrm{v}[\mathrm{m}]}$ & \multicolumn{3}{|c|}{$23,2 \mathrm{~mm}^{2} / \mathrm{mm}^{3}$} & $\mathrm{~S}_{\mathrm{v}[\mathrm{m}]}$ & \multicolumn{3}{|c|}{$28,0 \mathrm{~mm}^{2} / \mathrm{mm}^{3}$} & $\mathrm{~S}_{\mathrm{v}[\mathrm{m}]}$ & \multicolumn{3}{|c|}{$31,7 \mathrm{~mm}^{2} / \mathrm{mm}^{3}$} & $S_{v[m]}$ & \multicolumn{3}{|c|}{$28,0 \mathrm{~mm}^{2} / \mathrm{mm}^{3}$} \\
\hline $\mathbf{L}_{\mathrm{v}[\mathrm{m}]}$ & \multicolumn{3}{|c|}{$396,7 \mathrm{~mm} / \mathrm{mm}^{3}$} & $\mathbf{L}_{\mathrm{v}[\mathrm{m}]}$ & \multicolumn{3}{|c|}{$281,0 \mathrm{~mm} / \mathrm{mm}^{3}$} & $\mathbf{L}_{v[\mathrm{~m}]}$ & \multicolumn{3}{|c|}{$429,8 \mathrm{~mm} / \mathrm{mm}^{3}$} & $\mathbf{L}_{\mathrm{v}[\mathrm{m}]}$ & \multicolumn{3}{|c|}{$380,2 \mathrm{~mm} / \mathrm{mm}^{3}$} & $\mathbf{L}_{\mathrm{v}[\mathrm{m}]}$ & \multicolumn{3}{|c|}{$396,7 \mathrm{~mm} / \mathrm{mm}^{3}$} \\
\hline
\end{tabular}

$\mathbf{P}_{\mathbf{p}}=$ número de pontos-teste que tocam vasos; $\mathbf{Q}_{\mathbf{A}}=$ número de perfis por área; $\mathbf{I}=$ número de intersecções vasculares com arcos ciclóides 
Tabela 3 - Perfis por campo e valores das variáveis estereológicas calculados para o córtex e junção corticomedular do timo de cada animal do grupo III

\begin{tabular}{|c|c|c|c|c|c|c|c|c|c|c|c|c|c|c|c|c|c|c|c|}
\hline \multicolumn{4}{|c|}{ Grupo III (111 dias) } & \multicolumn{12}{|l|}{ Córtex } & Animal 5 & $\mathbf{P}_{\mathbf{P}}$ & I & $\mathbf{Q}_{\mathrm{A}}$ \\
\hline Campo 1 & 1 & 3 & 6 & Campo 1 & 1 & 4 & 7 & Campo 1 & 0 & 5 & 10 & Campo 1 & 3 & 6 & 8 & Campo 1 & 2 & 6 & 7 \\
\hline Campo 3 & 0 & 4 & 5 & Campo 3 & 0 & 4 & 8 & Campo 3 & 0 & 5 & 6 & Campo 3 & 0 & 5 & 5 & Campo 3 & 0 & 5 & 5 \\
\hline Campo 4 & 1 & 5 & 11 & Campo 4 & 2 & 3 & 6 & Campo 4 & 2 & 7 & 8 & Campo 4 & 2 & 8 & 3 & Campo 4 & 0 & 4 & 6 \\
\hline$S_{\mathrm{v}[c]}$ & \multicolumn{3}{|c|}{$25,6 \mathrm{~mm}^{2} / \mathrm{mm}^{3}$} & $\mathrm{~S}_{\mathrm{v}[\mathrm{c}]}$ & \multicolumn{3}{|c|}{$25,6 \mathrm{~mm}^{2} / \mathrm{mm}^{3}$} & $\mathrm{~S}_{\mathrm{v}[\mathrm{c}]}$ & \multicolumn{3}{|c|}{$37,8 \mathrm{~mm}^{2} / \mathrm{mm}^{3}$} & $\mathrm{~S}_{\mathrm{v}[\mathrm{c}]}$ & \multicolumn{3}{|c|}{$35,4 \mathrm{~mm}^{2} / \mathrm{mm}^{3}$} & $\mathrm{~S}_{\mathrm{v}[\mathrm{c}]}$ & \multicolumn{3}{|c|}{$3,6, \mathrm{~mm}^{2} / \mathrm{mm}^{3}$} \\
\hline $\mathrm{L}_{\mathrm{v}[\mathrm{c}]}$ & \multicolumn{3}{|c|}{$595,0 \mathrm{~mm} / \mathrm{mm}^{3}$} & $\mathrm{~L}_{\mathrm{v}[\mathrm{c}]}$ & \multicolumn{3}{|c|}{$512,4 \mathrm{~mm} / \mathrm{mm}^{3}$} & $\mathrm{~L}_{\mathrm{v}[\mathrm{c}]}$ & \multicolumn{3}{|c|}{$694,2 \mathrm{~mm} / \mathrm{mm}^{3}$} & $\mathrm{~L}_{\mathrm{v}[\mathrm{c}]}$ & \multicolumn{3}{|c|}{$479,3 \mathrm{~mm} / \mathrm{mm}^{3}$} & $\mathrm{~L}_{\mathrm{v}[\mathrm{c}]}$ & \multicolumn{3}{|c|}{$512,4 \mathrm{~mm} / \mathrm{mm}^{3}$} \\
\hline
\end{tabular}

\section{Junção Corticomedular}

\begin{tabular}{|c|c|c|c|c|c|c|c|c|c|c|c|c|c|c|c|c|c|c|c|}
\hline Animal 1 & $\mathbf{P}_{\mathbf{P}}$ & I & $\mathbf{Q}_{\mathrm{A}}$ & Animal 2 & $\mathbf{P}_{\mathbf{P}}$ & I & $\mathbf{Q}_{\mathbf{A}}$ & Animal 3 & $\mathbf{P}_{\mathbf{P}}$ & I & $\mathbf{Q}_{\mathrm{A}}$ & Animal 4 & $\mathbf{P}_{\mathbf{P}}$ & I & $\mathbf{Q}_{\mathrm{A}}$ & Animal 5 & $\mathbf{P}_{\mathbf{P}}$ & I & $\mathbf{Q}_{\mathbf{A}}$ \\
\hline Campo 1 & 5 & 9 & 4 & Campo 1 & 2 & 9 & 6 & Campo 1 & 1 & 6 & 3 & Campo 1 & 1 & 3 & 5 & Campo 1 & 4 & 5 & 4 \\
\hline Campo 2 & 4 & 9 & 9 & Campo 2 & 2 & 4 & 5 & Campo 2 & 2 & 4 & 4 & Campo 2 & 4 & 8 & 3 & Campo 2 & 1 & 11 & 4 \\
\hline Campo 3 & 3 & 11 & 5 & Campo 3 & 1 & 8 & 5 & Campo 3 & 2 & 3 & 4 & Campo 3 & 3 & 4 & 6 & Campo 3 & 2 & 7 & 6 \\
\hline Campo 4 & 3 & 6 & 4 & Campo 4 & 3 & 5 & 5 & Campo 4 & 1 & 7 & 6 & Campo 4 & 4 & 4 & 5 & Campo 4 & 6 & 8 & 5 \\
\hline Campo 5 & 2 & 8 & 8 & Campo 5 & 1 & 6 & 4 & Campo 5 & 0 & 5 & 3 & Campo 5 & 2 & 5 & 5 & Campo 5 & 1 & 10 & 5 \\
\hline $\mathrm{V}_{\mathrm{v}[\mathrm{m}]}$ & \multicolumn{3}{|c|}{$21,3 \%$} & $\mathbf{V}_{\mathrm{v}[\mathrm{m}]}$ & \multicolumn{3}{|c|}{$11,3 \%$} & $\mathbf{V}_{\mathrm{v}[\mathrm{m}]}$ & $7,5 \%$ & & & $\mathbf{V}_{\mathrm{v}[\mathrm{m}]}$ & \multicolumn{3}{|c|}{$17,5 \%$} & $\mathrm{~V}_{\mathrm{v}[\mathrm{m}]}$ & \multicolumn{3}{|c|}{$15,6 \%$} \\
\hline $\mathrm{S}_{\mathrm{v}[\mathrm{m}]}$ & \multicolumn{3}{|c|}{$52,4 \mathrm{~mm}^{2} / \mathrm{mm}^{3}$} & $\mathrm{~S}_{\mathrm{v}[\mathrm{m}]}$ & \multicolumn{3}{|c|}{$39,0 \mathrm{~mm}^{2} / \mathrm{mm}^{3}$} & $\mathrm{~S}_{\mathrm{v}[\mathrm{m}]}$ & \multicolumn{3}{|c|}{$30,5 \mathrm{~mm}^{2} / \mathrm{mm}^{3}$} & $\mathrm{~S}_{\mathrm{v}[\mathrm{m}]}$ & \multicolumn{3}{|c|}{$29,3 \mathrm{~mm}^{2} / \mathrm{mm}^{3}$} & $\mathrm{~S}_{\mathrm{v}[\mathrm{m}]}$ & \multicolumn{3}{|c|}{$54,9 \mathrm{~mm}^{2} / \mathrm{mm}^{3}$} \\
\hline $\mathbf{L}_{v[\mathrm{~m}]}$ & \multicolumn{3}{|c|}{$495,9 \mathrm{~mm} / \mathrm{mm}^{3}$} & $\mathbf{L}_{\mathrm{v}[\mathrm{m}]}$ & \multicolumn{3}{|c|}{$413,2 \mathrm{~mm} / \mathrm{mm}^{3}$} & $\mathbf{L}_{v[\mathrm{~m}]}$ & \multicolumn{3}{|c|}{$330,6 \mathrm{~mm} / \mathrm{mm}^{3}$} & $\mathbf{L}_{v[\mathrm{~m}]}$ & \multicolumn{3}{|c|}{$396,7 \mathrm{~mm} / \mathrm{mm}^{3}$} & $\mathbf{L}_{v[\mathrm{~m}]}$ & \multicolumn{3}{|c|}{$413,2 \mathrm{~mm} / \mathrm{mm}^{3}$} \\
\hline
\end{tabular}

$\mathbf{P}_{\mathbf{p}}=$ número de pontos-teste que tocam vasos; $\mathbf{Q}_{\mathbf{A}}=$ número de perfis por área; I = número de intersecções vasculares com arcos ciclóides 
Tabela 4 - Perfis por campo e valores das variáveis estereológicas calculados para o córtex e junção corticomedular do timo de cada animal do grupo IV

\begin{tabular}{|c|c|c|c|c|c|c|c|c|c|c|c|c|c|c|c|c|c|c|c|}
\hline \multicolumn{4}{|c|}{ Grupo IV (5 meses) } & \multicolumn{12}{|l|}{ Córtex } & Animal 5 & $\mathbf{P}_{\mathbf{P}}$ & 1 & $\mathbf{Q}_{\mathrm{A}}$ \\
\hline Campo 1 & 1 & 2 & 2 & Campo 1 & 1 & 2 & 2 & Campo 1 & 1 & 4 & 4 & Campo 1 & 0 & 2 & 4 & Campo 1 & 0 & 1 & 3 \\
\hline Campo 3 & 0 & 2 & 2 & Campo 3 & 1 & 2 & 2 & Campo 3 & 0 & 2 & 1 & Campo 3 & 0 & 4 & 3 & Campo 3 & 0 & 4 & 6 \\
\hline Campo 4 & 1 & 2 & 2 & Campo 4 & 0 & 0 & 1 & Campo 4 & 0 & 2 & 3 & Campo 4 & 1 & 0 & 2 & Campo 4 & 1 & 4 & 3 \\
\hline$S_{\mathrm{v}[c]}$ & \multicolumn{3}{|c|}{$12,2 \mathrm{~mm}^{2} / \mathrm{mm}^{3}$} & $\mathrm{~S}_{\mathrm{v}[\mathrm{c}]}$ & \multicolumn{3}{|c|}{$9,8 \mathrm{~mm}^{2} / \mathrm{mm}^{3}$} & $\mathrm{~S}_{\mathrm{v}[\mathrm{c}]}$ & \multicolumn{3}{|c|}{$20,7 \mathrm{~mm}^{2} / \mathrm{mm}^{3}$} & $\mathrm{~S}_{\mathrm{v}[\mathrm{c}]}$ & \multicolumn{3}{|c|}{$9,8 \mathrm{~mm}^{2} / \mathrm{mm}^{3}$} & $\mathrm{~S}_{\mathrm{v}[\mathrm{c}]}$ & \multicolumn{3}{|c|}{$13,4 \mathrm{~mm}^{2} / \mathrm{mm}^{3}$} \\
\hline $\mathrm{L}_{\mathrm{v}[\mathrm{c}]}$ & \multicolumn{3}{|c|}{$181,8 \mathrm{~mm} / \mathrm{mm}^{3}$} & $\mathrm{~L}_{\mathrm{v}[\mathrm{c}]}$ & \multicolumn{3}{|c|}{$181,8 \mathrm{~mm} / \mathrm{mm}^{3}$} & $\mathrm{~L}_{\mathrm{v}[\mathrm{c}]}$ & \multicolumn{3}{|c|}{$231,4 \mathrm{~mm} / \mathrm{mm}^{3}$} & $\mathrm{~L}_{\mathrm{v}[\mathrm{c}]}$ & \multicolumn{3}{|c|}{$231,4 \mathrm{~mm} / \mathrm{mm}^{3}$} & $\mathrm{~L}_{\mathrm{v}[\mathrm{c}]}$ & \multicolumn{3}{|c|}{$264,5 \mathrm{~mm} / \mathrm{mm}^{3}$} \\
\hline
\end{tabular}

\section{Junção Corticomedular}

\begin{tabular}{|c|c|c|c|c|c|c|c|c|c|c|c|c|c|c|c|c|c|c|c|}
\hline Animal 1 & $\mathbf{P}_{\mathbf{P}}$ & I & $\mathbf{Q}_{\mathrm{A}}$ & Animal 2 & $\mathbf{P}_{\mathbf{P}}$ & I & $Q_{A}$ & Animal 3 & $\mathbf{P}_{\mathbf{P}}$ & I & $\mathbf{Q}_{\mathrm{A}}$ & Animal 4 & $\mathbf{P}_{\mathbf{P}}$ & I & $\mathbf{Q}_{\mathrm{A}}$ & Animal 5 & $\mathbf{P}_{\mathbf{P}}$ & I & $\mathbf{Q}_{\mathbf{A}}$ \\
\hline Campo 1 & 1 & 5 & 6 & Campo 1 & 1 & 6 & 4 & Campo 1 & 2 & 7 & 3 & Campo 1 & 1 & 5 & 3 & Campo 1 & 0 & 6 & 4 \\
\hline Campo 2 & 1 & 4 & 4 & Campo 2 & 2 & 7 & 7 & Campo 2 & 0 & 6 & 4 & Campo 2 & 2 & 3 & 2 & Campo 2 & 1 & 2 & 3 \\
\hline Campo 3 & 2 & 9 & 4 & Campo 3 & 0 & 8 & 5 & Campo 3 & 1 & 4 & 7 & Campo 3 & 0 & 4 & 3 & Campo 3 & 0 & 4 & 4 \\
\hline Campo 4 & 2 & 5 & 4 & Campo 4 & 1 & 7 & 6 & Campo 4 & 1 & 2 & 4 & Campo 4 & 1 & 2 & 4 & Campo 4 & 2 & 4 & 4 \\
\hline Campo 5 & 1 & 2 & 3 & Campo 5 & 1 & 5 & 4 & Campo 5 & 0 & 9 & 4 & Campo 5 & 2 & 6 & 4 & Campo 5 & 3 & 3 & 2 \\
\hline $\mathrm{V}_{\mathrm{v}[\mathrm{m}]}$ & \multicolumn{3}{|c|}{$8,8 \%$} & $\mathrm{~V}_{\mathrm{v}[\mathrm{m}]}$ & \multicolumn{3}{|c|}{$6,3 \%$} & $\mathrm{~V}_{\mathrm{v}[\mathrm{m}]}$ & \multicolumn{3}{|c|}{$5,0 \%$} & $\mathrm{~V}_{\mathrm{v}[\mathrm{m}]}$ & \multicolumn{3}{|c|}{$7,5 \%$} & $\mathrm{~V}_{\mathrm{v}[\mathrm{m}]}$ & \multicolumn{3}{|c|}{$7,5 \%$} \\
\hline $\mathrm{S}_{\mathrm{v}[\mathrm{m}]}$ & \multicolumn{3}{|c|}{$30,5 \mathrm{~mm}^{2} / \mathrm{mm}^{3}$} & $\mathrm{~S}_{\mathrm{v}[\mathrm{m}]}$ & \multicolumn{3}{|c|}{$40,2 \mathrm{~mm}^{2} / \mathrm{mm}^{3}$} & $\mathrm{~S}_{\mathrm{v}[\mathrm{m}]}$ & \multicolumn{3}{|c|}{$34,1 \mathrm{~mm}^{2} / \mathrm{mm}^{3}$} & $\mathrm{~S}_{\mathrm{v}[\mathrm{m}]}$ & \multicolumn{3}{|c|}{$24,4 \mathrm{~mm}^{2} / \mathrm{mm}^{3}$} & $\mathrm{~S}_{\mathrm{v}[\mathrm{m}]}$ & \multicolumn{3}{|c|}{$23,2 \mathrm{~mm}^{2} / \mathrm{mm}^{3}$} \\
\hline $\mathrm{L}_{\mathrm{v}[\mathrm{m}]}$ & \multicolumn{3}{|c|}{$347,1 \mathrm{~mm} / \mathrm{mm}^{3}$} & $\mathrm{~L}_{\mathrm{v}[\mathrm{m}]}$ & \multicolumn{3}{|c|}{$429,8 \mathrm{~mm} / \mathrm{mm}^{3}$} & $\mathrm{~L}_{\mathrm{v}[\mathrm{m}]}$ & \multicolumn{3}{|c|}{$363,6 \mathrm{~mm} / \mathrm{mm}^{3}$} & $\mathrm{~L}_{\mathrm{v}[\mathrm{m}]}$ & \multicolumn{3}{|c|}{$264,5 \mathrm{~mm} / \mathrm{mm}^{3}$} & $\mathrm{~L}_{\mathrm{v}[\mathrm{m}]}$ & \multicolumn{3}{|c|}{$281,0 \mathrm{~mm} / \mathrm{mm}^{3}$} \\
\hline
\end{tabular}

$\mathbf{P}_{\mathbf{p}}=$ número de pontos-teste que tocam vasos; $\mathbf{Q}_{\mathbf{A}}=$ número de perfis por área; I = número de intersecções vasculares com arcos ciclóides 
Tabela 5 - Perfis por campo e valores das variáveis estereológicas calculados para o córtex e junção corticomedular do timo de cada animal do grupo $\mathrm{V}$

\begin{tabular}{|c|c|c|c|c|c|c|c|c|c|c|c|c|c|c|c|c|c|c|c|}
\hline \multicolumn{4}{|c|}{ Grupo V (2 anos) } & \multicolumn{12}{|l|}{ Córtex } & \multirow[b]{2}{*}{ Animal 5} & \multirow[b]{2}{*}{$\mathbf{P}_{\mathbf{P}}$} & \multirow[b]{2}{*}{ I } & \multirow[b]{2}{*}{$\mathbf{Q}_{\mathrm{A}}$} \\
\hline Animal 1 & $\mathbf{P}_{\mathbf{P}}$ & I & $\mathbf{Q}_{\mathrm{A}}$ & Animal 2 & $\mathbf{P}_{\mathbf{p}}$ & I & $\mathbf{Q}_{\mathrm{A}}$ & Animal 3 & $\mathbf{P}_{\mathbf{P}}$ & I & $\mathbf{Q}_{\mathrm{A}}$ & Animal 4 & $\mathbf{P}_{\mathbf{P}}$ & I & $\mathbf{Q}_{\mathrm{A}}$ & & & & \\
\hline Campo 1 & 0 & 2 & 2 & Campo 1 & 1 & 2 & 1 & Campo 1 & 0 & 0 & 2 & Campo 1 & 1 & 1 & 3 & Campo 1 & 1 & 4 & 3 \\
\hline Campo 2 & 1 & 0 & 2 & Campo 2 & 0 & 0 & 1 & Campo 2 & 0 & 0 & 1 & Campo 2 & 1 & 2 & 2 & Campo 2 & 0 & 0 & 4 \\
\hline Campo 3 & 0 & 2 & 1 & Campo 3 & 1 & 0 & 0 & Campo 3 & 0 & 0 & 2 & Campo 3 & 0 & 2 & 2 & Campo 3 & 0 & 2 & 3 \\
\hline Campo 4 & 1 & 2 & 3 & Campo 4 & 0 & 0 & 2 & Campo 4 & 0 & 2 & 2 & Campo 4 & 0 & 0 & 1 & Campo 4 & 0 & 2 & 2 \\
\hline $\mathrm{S}_{\mathrm{v}[\mathrm{c}]}$ & \multicolumn{3}{|c|}{$9,8 \mathrm{~mm}^{2} / \mathrm{mm}^{3}$} & $\mathrm{~S}_{\mathrm{v}[\mathrm{c}]}$ & \multicolumn{3}{|c|}{$4,9 \mathrm{~mm}^{2} / \mathrm{mm}^{3}$} & $\mathrm{~S}_{\mathrm{v}[\mathrm{c}]}$ & $4,9 n$ & $n^{2} / n$ & & $\mathbf{S}_{\mathrm{v}[\mathrm{c}]}$ & \multicolumn{3}{|c|}{$8,5 \mathrm{~mm}^{2} / \mathrm{mm}^{3}$} & $S_{v[c]}$ & \multicolumn{3}{|c|}{$12,2 \mathrm{~mm}^{2} / \mathrm{mm}^{3}$} \\
\hline $\mathrm{L}_{\mathrm{v}[\mathrm{c}]}$ & \multicolumn{3}{|c|}{$148,8 \mathrm{~mm} / \mathrm{mm}^{3}$} & $\mathbf{L}_{\mathrm{v}[\mathrm{cc}]}$ & \multicolumn{3}{|c|}{$82,6 \mathrm{~mm} / \mathrm{mm}^{3}$} & $\mathrm{~L}_{\mathrm{v}[\mathrm{c}]}$ & 165,3 & $\mathrm{~mm}$ & $\mathrm{~nm}^{3}$ & $\mathrm{~L}_{\mathrm{v}[\mathrm{c}]}$ & \multicolumn{3}{|c|}{$181,8 \mathrm{~mm} / \mathrm{mm}^{3}$} & $\mathrm{~L}_{\mathrm{v}[\mathrm{cc}]}$ & \multicolumn{3}{|c|}{$214,9 \mathrm{~mm} / \mathrm{mm}^{3}$} \\
\hline
\end{tabular}

\section{Junção Corticomedular}

\begin{tabular}{|c|c|c|c|c|c|c|c|c|c|c|c|c|c|c|c|c|c|c|c|}
\hline Animal 1 & $\mathbf{P}_{\mathbf{P}}$ & I & $\mathbf{Q}_{\mathrm{A}}$ & Animal 2 & $\mathbf{P}_{\mathbf{P}}$ & I & $\mathbf{Q}_{\mathrm{A}}$ & Animal 3 & $\mathbf{P}_{\mathbf{P}}$ & I & $\mathbf{Q}_{\mathbf{A}}$ & Animal 4 & $\mathbf{P}_{\mathbf{P}}$ & I & $\mathbf{Q}_{\mathbf{A}}$ & Animal 5 & $\mathbf{P}_{\mathbf{P}}$ & I & $\mathbf{Q}_{\mathbf{A}}$ \\
\hline Campo 1 & 2 & 6 & 4 & Campo 1 & 0 & 4 & 4 & Campo 1 & 1 & 4 & 4 & Campo 1 & 1 & 5 & 4 & Campo 1 & 2 & 3 & 5 \\
\hline Campo 2 & 1 & 6 & 4 & Campo 2 & 3 & 4 & 3 & Campo 2 & 0 & 5 & 3 & Campo 2 & 1 & 2 & 4 & Campo 2 & 1 & 4 & 3 \\
\hline Campo 3 & 2 & 7 & 7 & Campo 3 & 1 & 6 & 5 & Campo 3 & 2 & 4 & 6 & Campo 3 & 3 & 5 & 3 & Campo 3 & 1 & 6 & 4 \\
\hline Campo 4 & 0 & 3 & 5 & Campo 4 & 2 & 3 & 5 & Campo 4 & 2 & 1 & 4 & Campo 4 & 0 & 7 & 4 & Campo 4 & 0 & 4 & 5 \\
\hline Campo 5 & 1 & 6 & 4 & Campo 5 & 2 & 4 & 4 & Campo 5 & 0 & 5 & 4 & Campo 5 & 2 & 3 & 5 & Campo 5 & 0 & 2 & 3 \\
\hline $\mathrm{V}_{\mathrm{v}[\mathrm{m}]}$ & \multicolumn{3}{|l|}{$7,5 \%$} & $\mathbf{V}_{\mathrm{v}[\mathrm{m}]}$ & \multicolumn{3}{|c|}{$10,0 \%$} & $\mathbf{V}_{\mathrm{v}[\mathrm{m}]}$ & \multicolumn{3}{|c|}{$6,3 \%$} & $\mathbf{V}_{\mathrm{v}[\mathrm{m}]}$ & \multicolumn{3}{|c|}{$8,8 \%$} & $\mathbf{V}_{\mathrm{v}[\mathrm{m}]}$ & \multicolumn{3}{|c|}{$5,0 \%$} \\
\hline $\mathrm{S}_{\mathrm{v}[\mathrm{m}]}$ & \multicolumn{3}{|c|}{$34,1 \mathrm{~mm}^{2} / \mathrm{mm}^{3}$} & $\mathrm{~S}_{\mathrm{v}[\mathrm{m}]}$ & \multicolumn{3}{|c|}{$25,6 \mathrm{~mm}^{2} / \mathrm{mm}^{3}$} & $\mathrm{~S}_{\mathrm{v}[\mathrm{m}]}$ & \multicolumn{3}{|c|}{$23,2 \mathrm{~mm}^{2} / \mathrm{mm}^{3}$} & $\mathrm{~S}_{\mathrm{v}[\mathrm{m}]}$ & \multicolumn{3}{|c|}{$26,8 \mathrm{~mm}^{2} / \mathrm{mm}^{3}$} & $\mathrm{~S}_{\mathrm{v}[\mathrm{m}]}$ & \multicolumn{3}{|c|}{$23,2 \mathrm{~mm}^{2} / \mathrm{mm}^{3}$} \\
\hline $\mathbf{L}_{\mathrm{v}[\mathrm{m}]}$ & \multicolumn{3}{|c|}{$396,7 \mathrm{~mm} / \mathrm{mm}^{3}$} & $\mathbf{L}_{\mathrm{v}[\mathrm{m}]}$ & \multicolumn{3}{|c|}{$347,1 \mathrm{~mm} / \mathrm{mm}^{3}$} & $\mathbf{L}_{\mathrm{v}[\mathrm{m}]}$ & \multicolumn{3}{|c|}{$347,1 \mathrm{~mm} / \mathrm{mm}^{3}$} & $\mathbf{L}_{\mathrm{v}[\mathrm{m}]}$ & \multicolumn{3}{|c|}{$330,6 \mathrm{~mm} / \mathrm{mm}^{3}$} & $\mathbf{L}_{\mathrm{v}[\mathrm{m}]}$ & \multicolumn{3}{|c|}{$330,6 \mathrm{~mm} / \mathrm{mm}^{3}$} \\
\hline
\end{tabular}

$\mathbf{P}_{\mathbf{p}}=$ número de pontos-teste que tocam vasos; $\mathbf{Q}_{\mathbf{A}}=$ número de perfis por área; $\mathbf{I}=$ número de intersecções vasculares com arcos ciclóides 
Tabela 6 - Valores de $\mathrm{p}$ do pós-teste de Tukey para verificação das diferenças entre os valores das variáveis estereológicas estimadas no córtex dos timos de grupos suínos em idades pré e pós-natais

\begin{tabular}{|c|c|c|c|c|c|c|}
\hline Variável & Grupo & $\{1\}$ & $\{2\}$ & $\{3\}$ & $\{4\}$ & $\{5\}$ \\
\hline \multirow{5}{*}{$\mathrm{V}_{\mathrm{v}[\mathrm{c}]}$} & I (65 dias) $\{1\}$ & 0 & & & & \\
\hline & II (85 dias) $\{2\}$ & 0,806403 & 0 & & & \\
\hline & III (111 dias) $\{3\}$ & 0,232247 & 0,818084 & 0 & & \\
\hline & IV (5 meses) $\{4\}$ & $0,001668^{*}$ & $0,018066^{*}$ & 0,155345 & 0 & \\
\hline & $\mathrm{V}(2$ anos $)\{5\}$ & $0,000367^{*}$ & $0,003019^{*}$ & $0,031306^{*}$ & 0,922848 & 0 \\
\hline \multirow{5}{*}{$\mathrm{S}_{\mathrm{v}[\mathrm{c}]}$} & I (65 dias) $\{1\}$ & 0 & & & & \\
\hline & II (85 dias) $\{2\}$ & 0,583025 & 0 & & & \\
\hline & III (111 dias) $\{3\}$ & 0,647414 & 0,064849 & 0 & & \\
\hline & IV (5 meses) $\{4\}$ & $0,000132^{*}$ & $0,000132^{*}$ & $0,000154^{*}$ & 0 & \\
\hline & $\mathrm{V}(2$ anos $)\{5\}$ & $0,000132^{*}$ & $0,000132^{*}$ & $0,000132^{*}$ & 0,453198 & 0 \\
\hline \multirow{5}{*}{$\mathrm{L}_{\mathrm{v}[c]}$} & I (65 dias) $\{1\}$ & 0 & & & & \\
\hline & II (85 dias) $\{2\}$ & 0,999991 & 0 & & & \\
\hline & III (111 dias) $\{3\}$ & 0,392416 & 0,435263 & 0 & & \\
\hline & IV (5 meses) $\{4\}$ & $0,000132^{*}$ & $0,000132^{*}$ & $0,000132^{*}$ & 0 & \\
\hline & $\mathrm{V}(2$ anos $)\{5\}$ & $0,000132^{*}$ & $0,000132^{*}$ & $0,000132^{*}$ & 0,622033 & 0 \\
\hline
\end{tabular}

$\left(^{*}\right)$ Diferença estatisticamente significativa $(p \leq 0,05)$ 
Tabela 7 - Valores de $p$ do pós-teste de Tukey para verificação das diferenças entre os valores das variáveis estereológicas estimadas na junção corticomedular dos timos de grupos suínos em idades pré e pós-natais

\begin{tabular}{|c|c|c|c|c|c|c|}
\hline Variável & Grupo & $\{1\}$ & $\{2\}$ & $\{3\}$ & $\{4\}$ & $\{5\}$ \\
\hline & I (65 dias) $\{1\}$ & 0 & & & & \\
\hline & II (85 dias) $\{2\}$ & 0,811959 & 0 & & & \\
\hline \multirow[t]{5}{*}{$\mathbf{V}_{\mathrm{v}[\mathrm{m}]}$} & III (111 dias) $\{3\}$ & $0,000264^{*}$ & $0,001791^{*}$ & 0 & & \\
\hline & IV (5 meses) $\{4\}$ & 0,582216 & 0,994145 & $0,004250^{*}$ & 0 & \\
\hline & $\mathrm{V}(2$ anos $)\{5\}$ & 0,423685 & 0,960096 & $0,007750^{*}$ & 0,998750 & 0 \\
\hline & I (65 dias) $\{1\}$ & 0 & & & & \\
\hline & II (85 dias) $\{2\}$ & 0,919839 & 0 & & & \\
\hline \multirow[t]{5}{*}{$\mathrm{S}_{\mathrm{v}[\mathrm{m}]}$} & III (111 dias) $\{3\}$ & $0,018493^{*}$ & 0,100405 & 0 & & \\
\hline & IV (5 meses) $\{4\}$ & 0,805395 & 0,998710 & 0,165615 & 0 & \\
\hline & $\mathrm{V}(2$ anos $)\{5\}$ & 0,999433 & 0,973401 & $0,029851^{*}$ & 0,903080 & 0 \\
\hline & I (65 dias) $\{1\}$ & 0 & & & & \\
\hline & II (85 dias) $\{2\}$ & 0,999649 & 0 & & & \\
\hline \multirow[t]{3}{*}{$\mathrm{L}_{\mathrm{v}[\mathrm{m}]}$} & III (111 dias) $\{3\}$ & 0,759057 & 0,857794 & 0 & & \\
\hline & IV (5 meses) $\{4\}$ & 0,857794 & 0,759057 & 0,229815 & 0 & \\
\hline & $\mathrm{V}(2$ anos $)\{5\}$ & 0,974709 & 0,930311 & 0,412527 & 0,994493 & 0 \\
\hline
\end{tabular}

$\left(^{*}\right)$ Diferença estatisticamente significativa $(p \leq 0,05)$ 
Tabela 8 - Valores de $\mathrm{p}$ do teste $t$ pareado para verificação das diferenças entre córtex e junção corticomedular dos timos de grupos suínos em idades pré e pós-natais

\begin{tabular}{clll}
\hline Grupo & $\mathbf{V}_{\mathbf{v}[\mathbf{v a s o}]}$ & $\mathbf{S}_{\mathrm{v}[\mathrm{vaso}]}$ & $\mathbf{L}_{\mathrm{v}[\mathrm{vaso}}$ \\
\hline I (65 dias) & $0,009^{*}$ & 0,07 & $0,001^{*}$ \\
II (85 dias) & 1,0 & $0,006^{*}$ & $0,004^{*}$ \\
III (111 dias) & $0,02^{*}$ & 0,3 & $0,05^{*}$ \\
IV (5 meses) & $0,009^{*}$ & $0,008^{*}$ & $0,05^{*}$ \\
V (2 anos) & $0,001^{*}$ & $0,001^{*}$ & $0,003^{*}$ \\
\hline
\end{tabular}

$\left({ }^{*}\right)$ Diferença estatisticamente significativa $(p \leq 0,05)$

\subsection{EXPRESSÃO RELATIVA DO mRNA DO VEGF E SEUS RECEPTORES (FIt-1 E KDR)}

A análise da expressão relativa do sistema VEGF-A no timo de suínos em relação ao controle endógeno GAPDH ao longo do desenvolvimento e em estágio de involução apresentou modificações significativas $(p<0,05)$ tempo-dependentes (Figura 9).

A expressão do mRNA do VEGF manteve-se constante no timo dos fetos ao longo da gestação, mas apresentou aumento significativo $(p<0,05)$ no timo dos animais de 5 meses, demonstrando mesmo nível de expressão nos animais de 2 anos de idade (Figura 9-A).

A expressão do mRNA do Flt-1 apresentou variação na durante a gestação. Os timos dos animais de 85 dias apresentaram tendência à elevação da expressão em relação aos dos animais de 65 dias e efetivamente apresentaram maior $(p<0,05)$ expressão em relação aos dos animais de 111 dias. Os timos dos animais de 5 meses de idade apresentaram elevação $(p<0,05)$ da expressão do mRNA do Flt-1 em relação aos timos dos fetos de 111 dias de gestação e também em relação aos dos animais de 2 anos de idade (Figura 9-B).

A expressão do mRNA do KDR no timo suíno seguiu o padrão de expressão do VEGF durante a gestação, ou seja, não houve diferença significativa entre as fases pré-natais estudadas. No entanto, nos animais de 5 meses de idade a expressão do KDR diminuiu $(p<0,05)$ em relação às fases pré-natais e também se 
apresentou menor $(p<0,05)$ em relação aos animais de 2 anos de idade. Não houve diferença significativa entre os animais das fases pré-natais e os animais de 2 anos de idade (Figura 9-C). 
VEGF

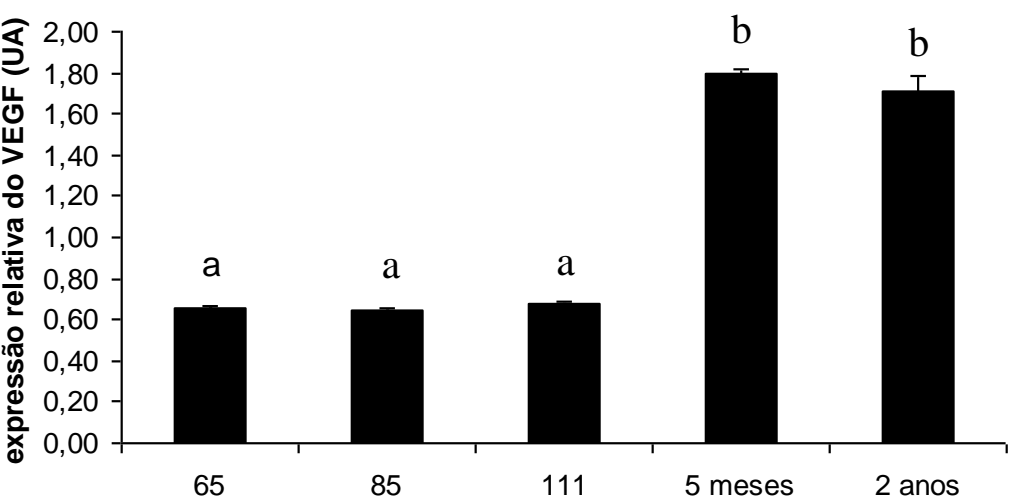

Flt-1

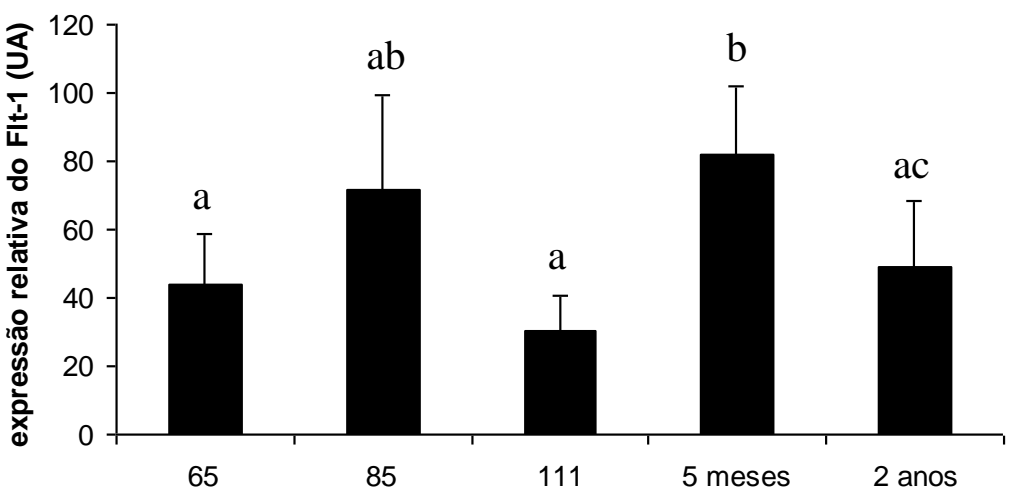

KDR

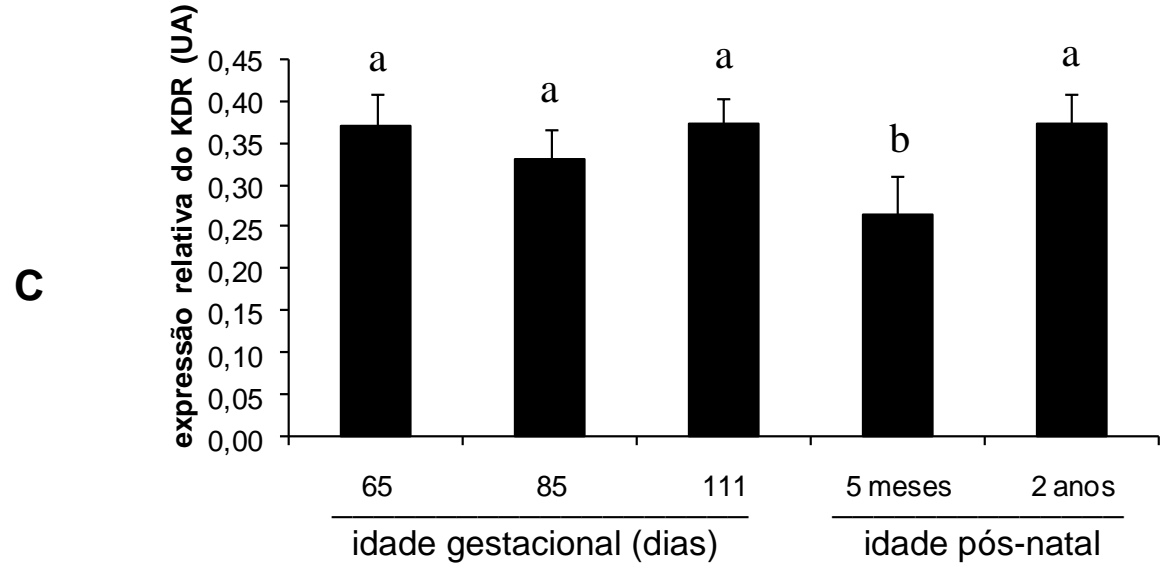

Gráfico 4 (A-C) - Expressão relativa do mRNA do VEGF (A), Flt-1 (B) e KDR (C) no timo suíno ao longo do seu desenvolvimento (65, 85 e 111 dias de gestação), maturação (5 meses de idade pós-natal) e em fase de involução (2 anos de idade). Gráficos representam a média \pm erro padrão (VEGF) ou desvio padrão (Flt-1 e KDR) dos 5 animais de cada grupo. Legenda: letras (a; b; c) correspondem a diferenças significativas entre os grupos $(p<0,05)$ 


\subsection{IMUNOLOCALIZAÇÃO DO VEGF E SEUS RECEPTORES (Flt-1 E KDR)}

Os resultados obtidos nas reações de imuno-histoquímica para VEGF e seus receptores (Flt-1 e KDR) no timo dos animais de todos os grupos experimentais estão descritos nas subseções desta seção.

\subsubsection{Imunolocalização do VEGF}

A proteína do VEGF foi identificada no timo suíno em todos os grupos pré e pós-natais estudados (Figuras 6, 7 e 8). Entretanto, sua expressão foi positiva ou negativa para certos tipos celulares de acordo com a idade, porém positiva com muito menos frequência em células dos grupos pós-natais.

Imunomarcação para VEGF foi observada em células epiteliais tímicas do córtex (CETc) e da medula (CETm) dos animais de todos os grupos pré-natais, como também em células migratórias (CMs) (timócitos e células de linhagem leucocitária). A imunomarcação de CETc foi observada em todos os três grupos prénatais, mas principalmente nos animais do grupo de 65 dias (Figura 6-A). Devido à grande densidade de timócitos na região, a distinção destas células foi dificultada à microscopia de luz e a identificação da imunomarcação se deu principalmente pela observação de marcação positiva em seus desmossomos, entre os quais se concentram populações de timócitos. CETm imunomarcadas foram observadas distribuídas por toda a região da medula dos grupos pré-natais (Figura 6-B, D e F), mas especialmente próximas a corpúsculos tímicos (CTs), sempre imunomarcados nesses grupos (Figura 6-B e F). CMs imunomarcadas foram observadas nas diferentes regiões do córtex, mas principalmente na região subcapsular (RS) e camada mais externa (Figura 6-A, C e E), assim como na JCM de todos os grupos pré-natais, principalmente nos de 111 dias (Figura 8-C). Imunomarcação foi observada também em CMs próximas a grandes vasos interlobulares de todos os grupos pré-natais, mas principalmente nos grupos de 85 (Figura 8-A) e 111 dias. 
No timo dos animais de 5 meses e 2 anos de idade foram raras as células imunomarcadas, sendo estas principalmente CMs localizadas na RS (Figura 7-A e C) e JCM (Figura 8-D) do órgão. CETm imunomarcadas foram observadas apenas próximo a CTs que, assim como nos grupos pré-natais, sempre se apresentaram imunomarcados (Figura 7-B e D).

Células endoteliais (CEs) apresentaram imunomarcação nos vasos sanguíneos interlobulares do timo dos animais dos grupos pré-natais (Figura 8-A), mas apenas naqueles de maior calibre. Imunomarcação foi raramente observada em CEs de capilares sanguíneos do córtex, porém CEs de vasos da medula e JCM se apresentaram sempre imunomarcadas (Figura 8-B e C) nestas fases. Nos grupos pós-natais foram observadas CEs imunomarcadas apenas nos vasos interlobulares e, dentre estes, nos mais calibrosos.

Nos grupos pré-natais, constituídos de machos e fêmeas, não observamos qualquer diferença entre os sexos. 
Córtex
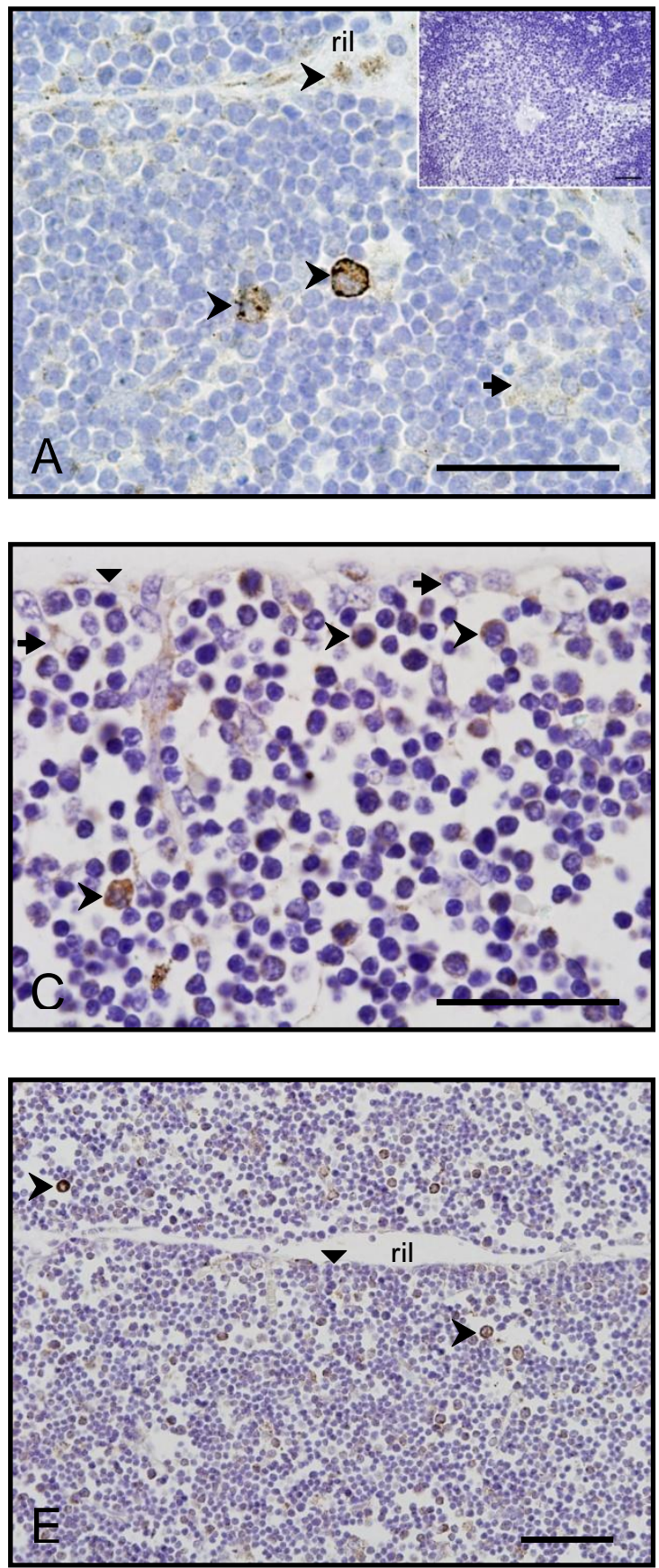

Medula
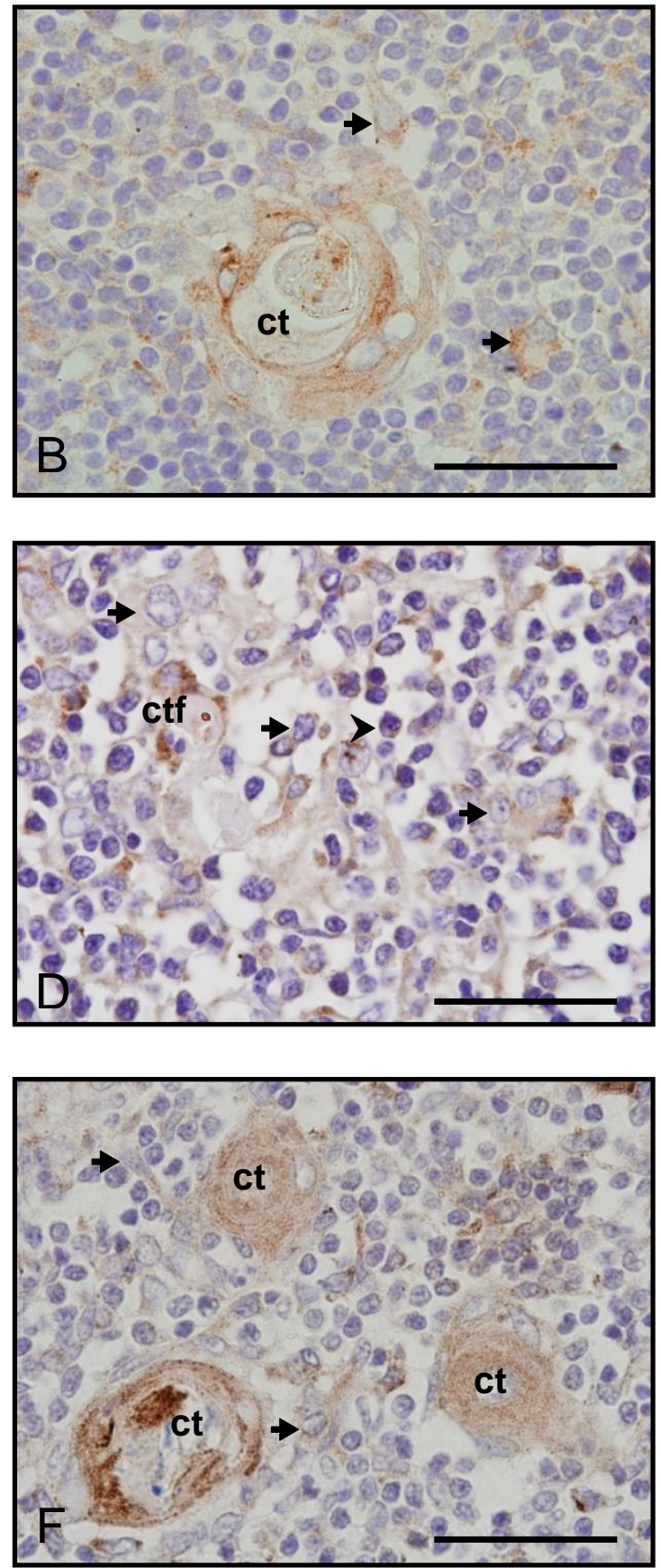

Figura $6(\mathrm{~A}-\mathrm{F})$ - Fotomicrografias da expressão da proteína VEGF no timo suíno. Reação imuno-histoquímica realizada com anticorpo policlonal antiVEGF (Santa Cruz sc 152) diluído 1:300. Amostras dos grupos prénatais: 65 (A e B), 85 (C e D) e 111 (E e F) dias de gestação. Legenda: ril, região interlobular; ct, corpúsculo tímico; ctf, corpúsculo tímico em formação; $>$, célula migratória; $\boldsymbol{\nabla}$, cápsula do órgão; $\rightarrow$, célula epitelial tímica (cortical ou medular). Notar a intercomunicação entre os desmossomos, muito mais aparente que nas células epiteliais tímicas do córtex devido à menor densidade celular da região. Inserção: controle negativo (vale para as figuras 7 e 8). Barras: $50 \mu \mathrm{m}$ 
Córtex
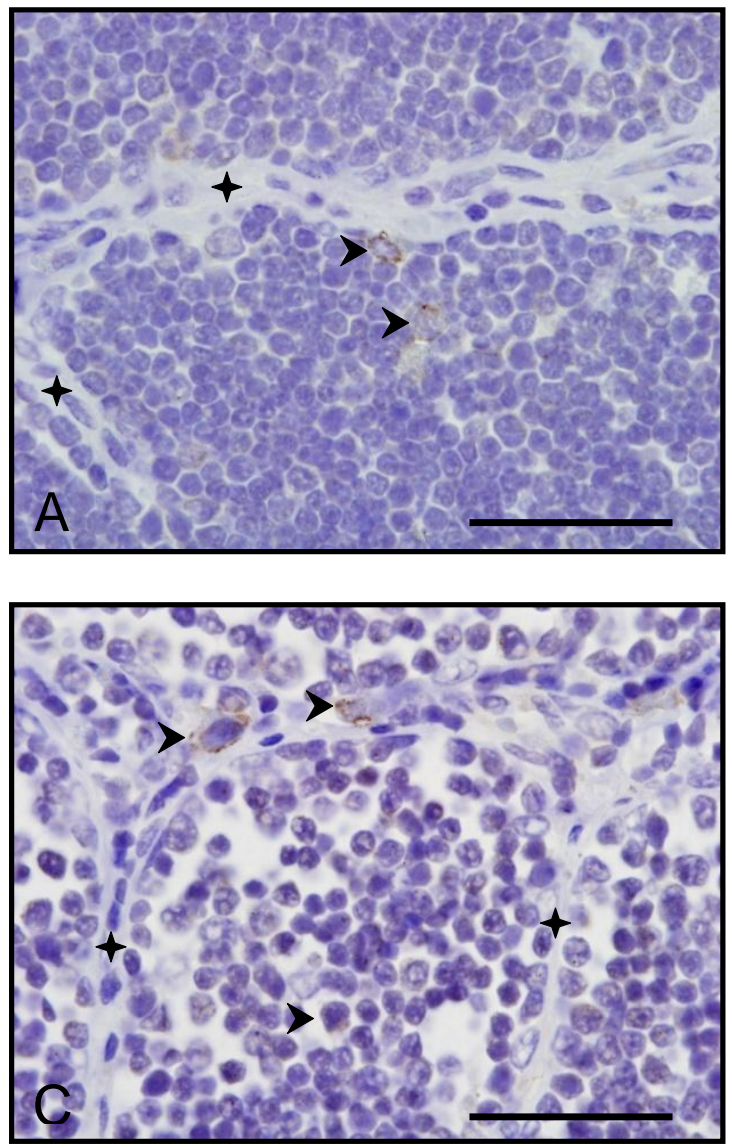

Figura $7(A-D)$ - Fotomicrografias da expressão da proteína VEGF no timo suíno. Reação imuno-histoquímica realizada com anticorpo policlonal antiVEGF (Santa Cruz SC 152) diluído 1:300. Amostras dos grupos pósnatais: 5 meses (A e B) e 2 anos de idade (C e D). Legenda: ct, corpúsculo tímico; $>$, célula migratória; $\boldsymbol{+}$, septo do órgão; $\rightarrow$, célula epitelial tímica. Barras: $50 \mu \mathrm{m}$ 

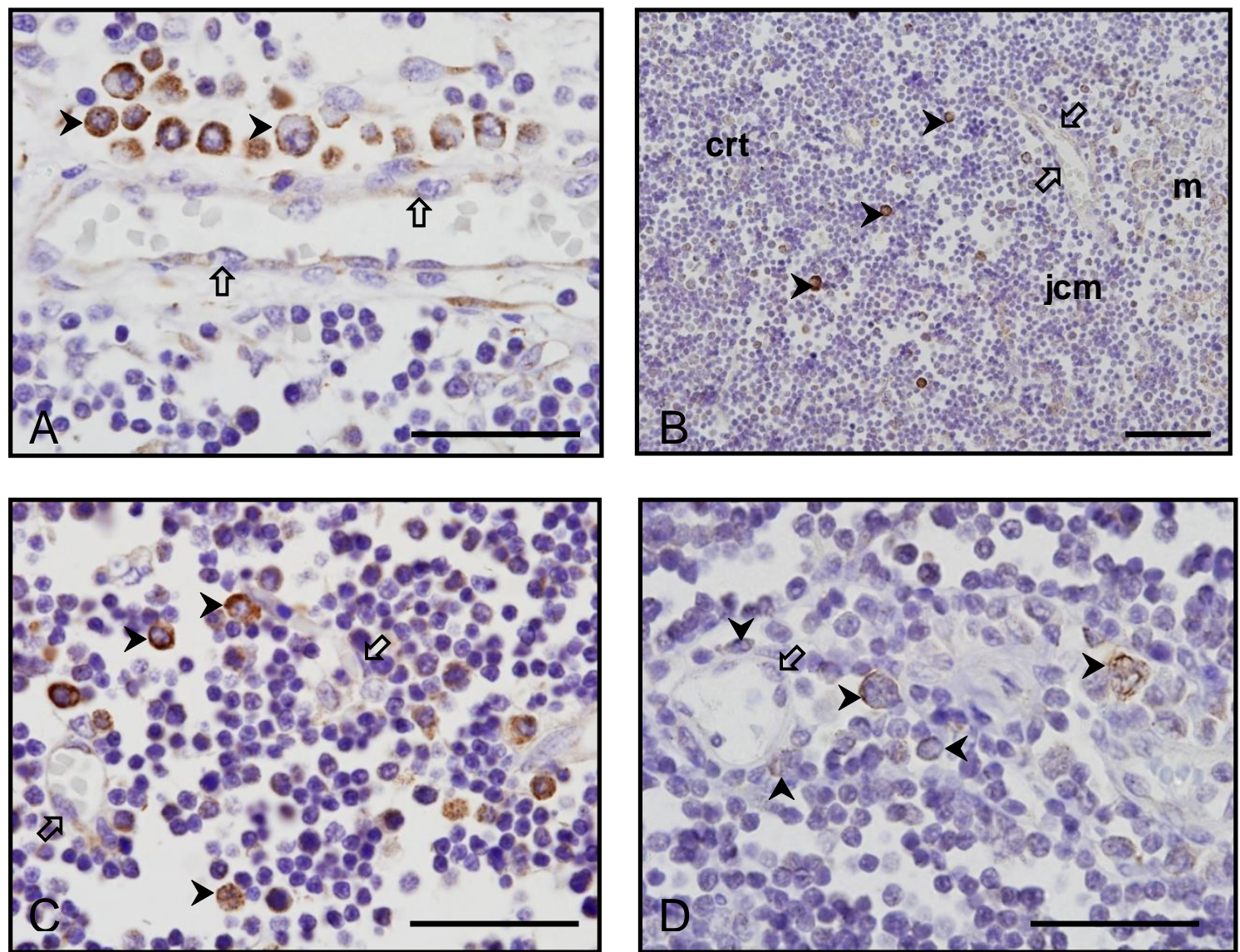

Figura $8(A-D)$ - Fotomicrografias da expressão da proteína VEGF no timo suíno. Reação imuno-histoquímica realizada com anticorpo policlonal antiVEGF (Santa Cruz sc 152) diluído 1:300. A) Região interlobular de um feto de 85 dias. B) Córtex (crt), medula (m) e junção corticomedular (jcm) de um feto de 111 dias. C) Ampliação da JCM de B. D) JCM de um animal de 5 meses de idade. Legenda: $\uparrow$, célula endotelial; >, célula migratória. Barras: $50 \mu \mathrm{m}$ 


\subsubsection{Imunolocalização do Flt-1}

Expressão positiva da proteína do Flt-1 (Figuras 9, 10 e 11) foi observada no timo suíno em todas as idades pré e pós-natais estudadas. Entretanto, os tipos celulares imunomarcados variaram entre os grupos e, assim como a proteína do VEGF, expressão mais rara foi observada no timo dos animais dos grupos de 5 meses e 2 anos de idade.

No córtex do timo dos animais de todas as fases pré-natais observamos CETc imunomarcadas, principalmente nos animais dos grupo de 65 dias (Figura 9-A), porém nos animais dos grupos pós-natais nenhuma imunomarcação em CETc foi observada (Figura 10-A e C). CETm apresentaram imunomarcação em todos os grupos pré e pós-natais, entretanto mais comumente nos animais de 65 dias (Figura 9-B), tornando-se raras nos animais dos grupos pós-natais (Figura 10-B e D), principalmente nos animais de 2 anos de idade (Figura 10-D). CTs apresentaram imunomarcação em todos os grupos pré (Figura 9-B, D e F), e pós-natais (Figura 10-B e D) estudados.

Em todos os grupos experimentais observamos CMs imunomarcadas pelo córtex, JCM e regiões interlobulares. Geralmente estas células se encontravam em proximidade com vasos sanguíneos e foram comumente observadas nos animais dos grupos pré-natais (Figura 9-C e E e Figura 11-A e C) e do grupo de 5 meses (Figura 10-A e Figura 11-B), mas raramente nos animais do grupo de 2 anos de idade (Figura 10-C e Figura 11-D).

Imunomarcação foi observada em CEs de vasos sanguíneos interlobulares e da JCM dos animais de todos os grupos pré-natais, mas principalmente dos animais de 65 dias (Figura 11-A). Os animais de 5 meses apresentaram CEs imunomarcadas em vasos interlobulares (Figura 11-B) e subcapsulares, enquanto que nenhuma CE imunomarcada foi observada nos animais do grupo de 2 anos de idade.

Nos grupos pré-natais, constituídos de machos e fêmeas, não observamos qualquer diferença entre os sexos. 


\section{Córtex}
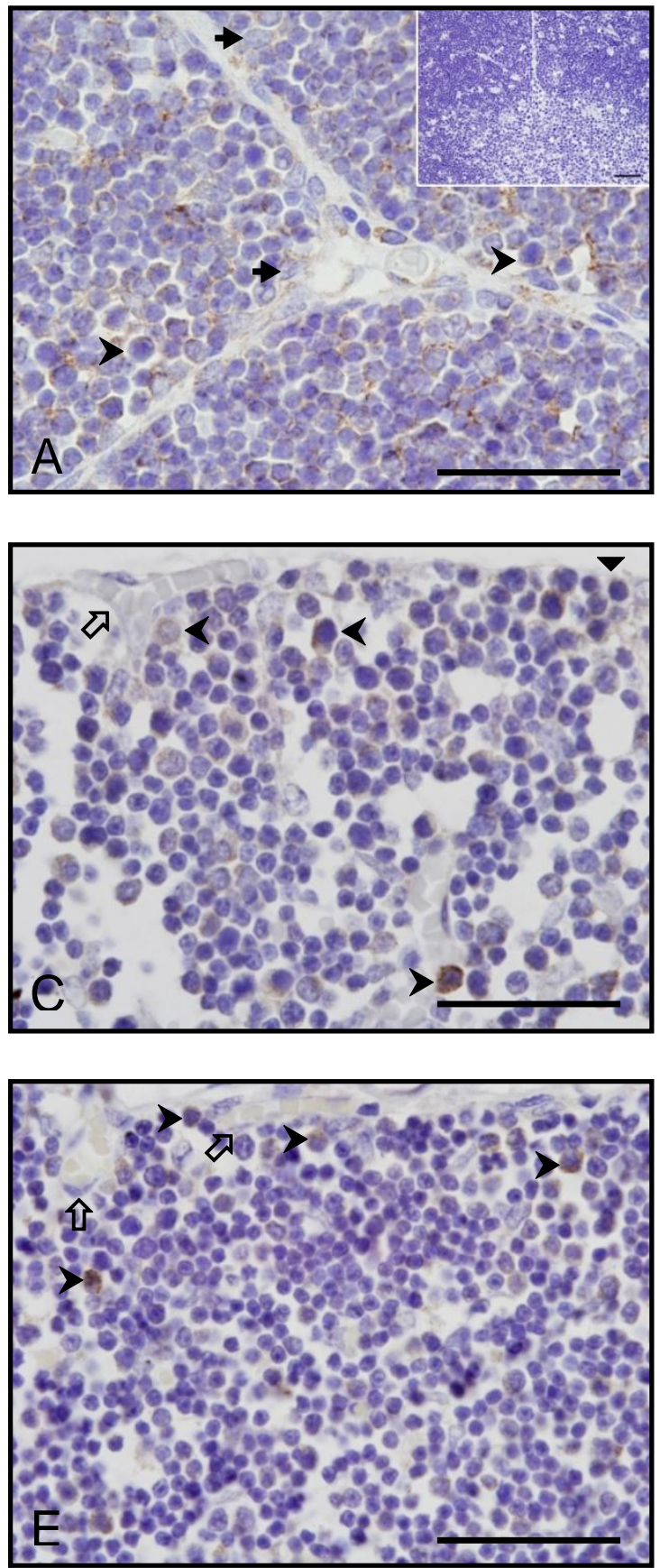

Medula
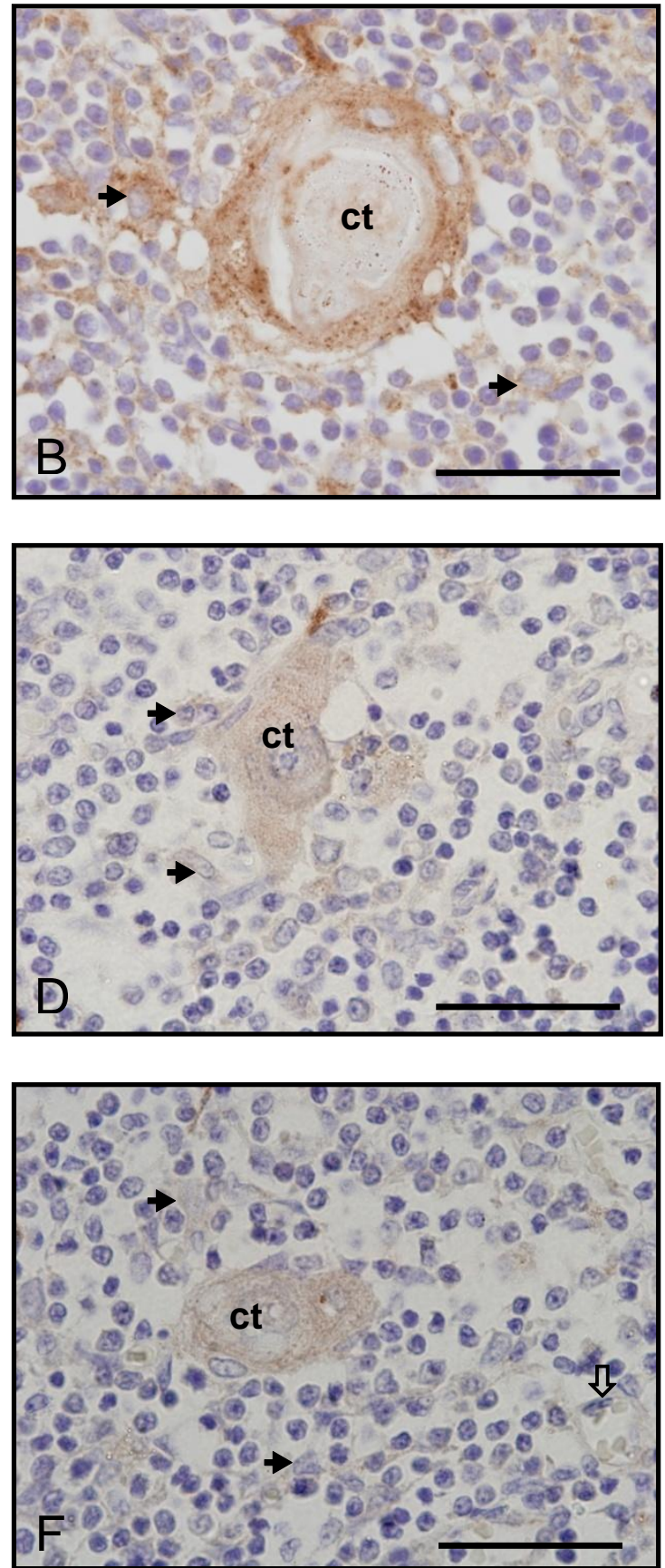

Figura $9(\mathrm{~A}-\mathrm{F})$ - Fotomicrografias da expressão da proteína Flt-1 no timo suíno. Reação imuno-histoquímica realizada com anticorpo policlonal antiFlt-1 (Santa Cruz sc 316) diluído 1:500. Amostras dos grupos prénatais: 65 (A e B), 85 (C e D) e 111 (E e F) dias de gestação. Legenda: ct, corpúsculo tímico; $\mathbf{\nabla}$, cápsula; $>$, célula migratória; + , septo; 仓, célula endotelial; $\rightarrow$, célula epitelial tímica. Inserção: controle negativo (vale para as figuras 10 e 11). Barras: $50 \mu \mathrm{m}$ 
Córtex
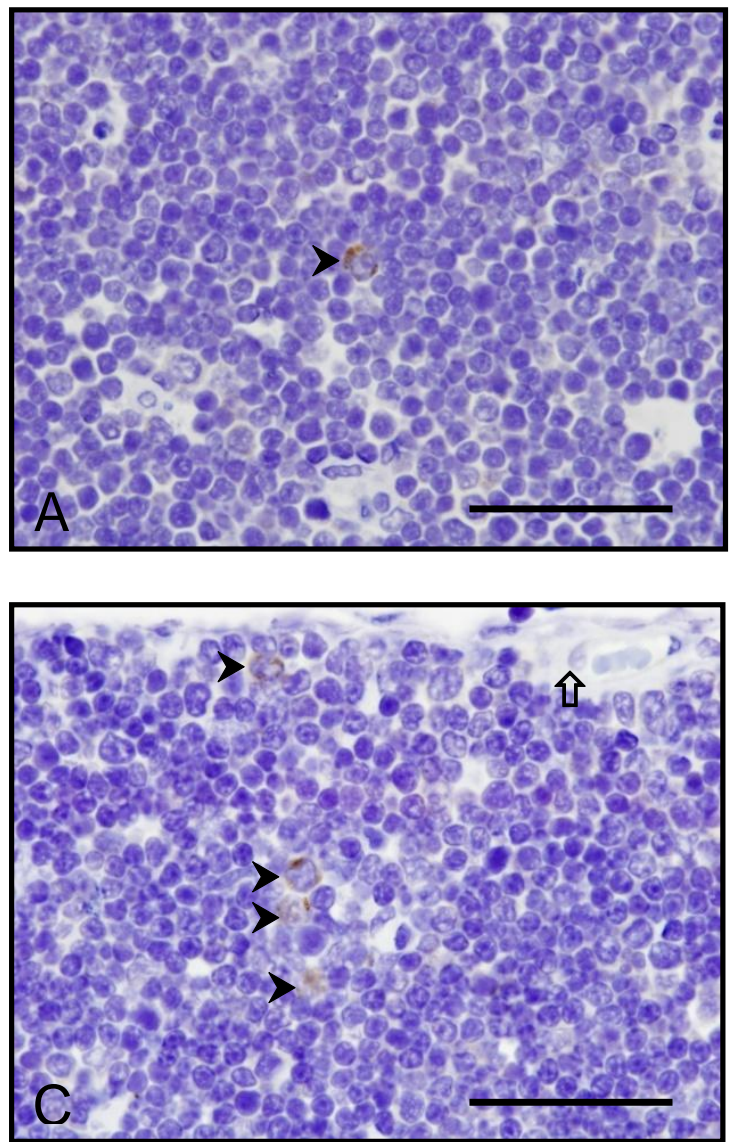

Medula
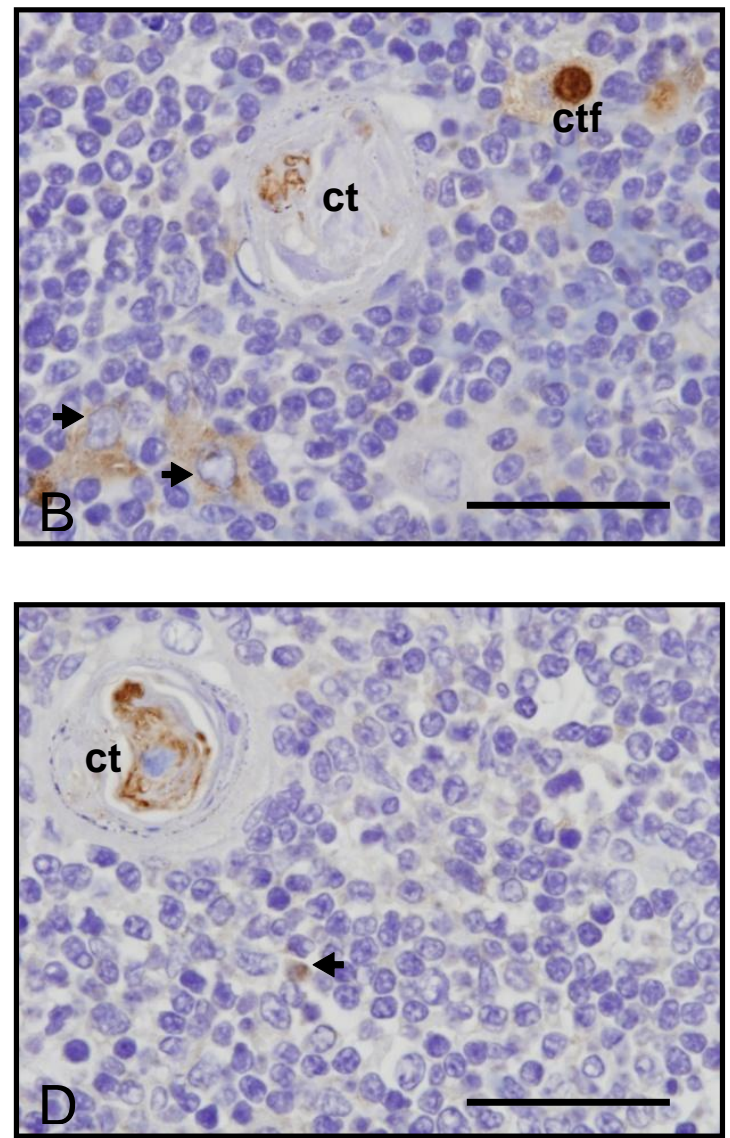

Figura $10(A-D)$ - Fotomicrografias da expressão da proteína Flt-1 no timo suíno. Reação imuno-histoquímica realizada com anticorpo policlonal antiFlt-1 (Santa Cruz sc 316) diluído 1:500. Amostras dos grupos pósnatais: 5 meses (A e B) e 2 anos de idade (C e D). Legenda: $>$, célula migratória; ct, corpúsculo tímico; ctf, corpúsculo tímico em formação; $\rightarrow$, célula epitelial tímica; $\uparrow$, célula endotelial. Note a ausência de marcação na grande maioria das CETc em A e C, e marcação em poucas CETm em B e D. Barras: $50 \mu \mathrm{m}$ 

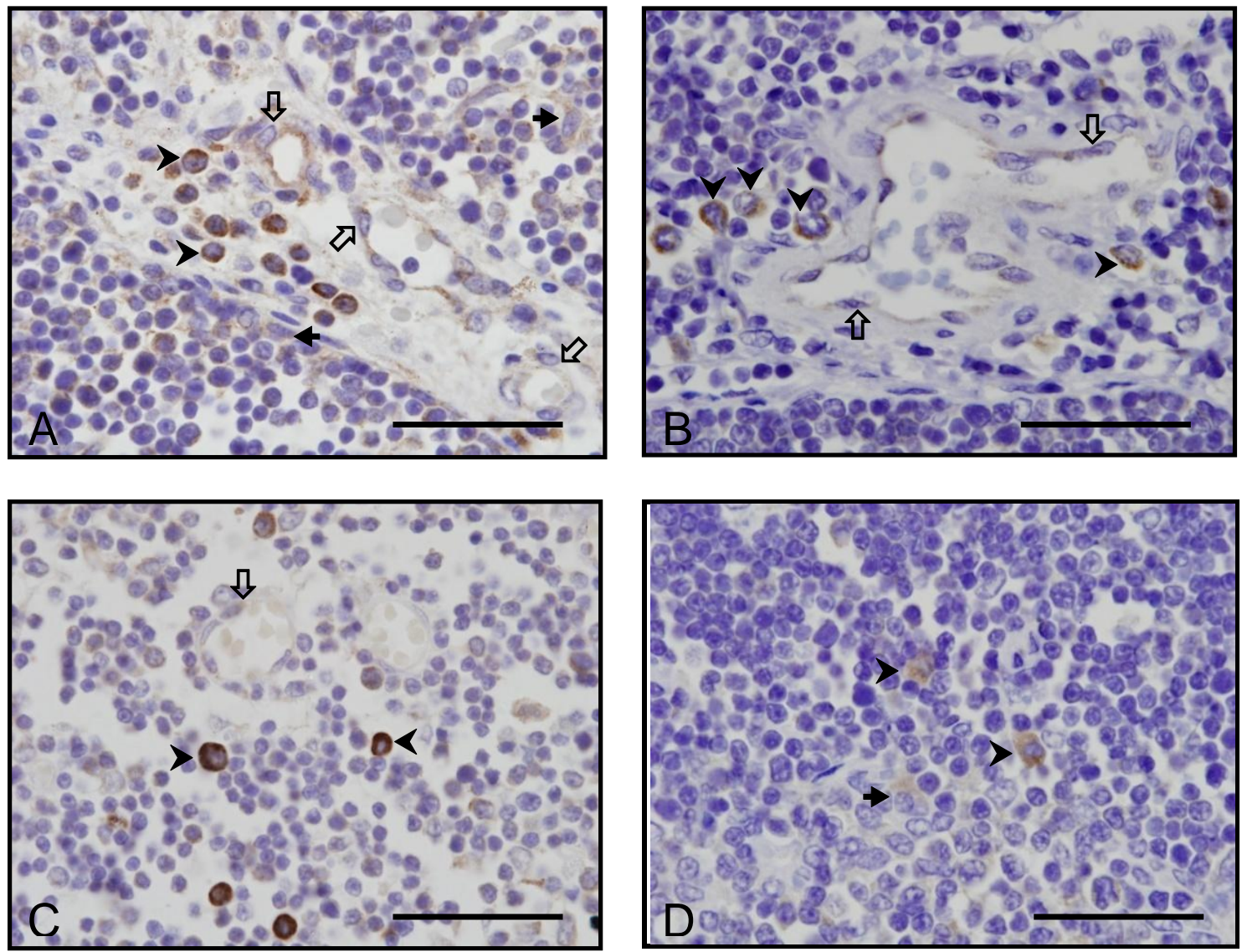

Figura $11(A-D)$ - Fotomicrografias da expressão da proteína Flt-1 no timo suíno. Reação imuno-histoquímica realizada com anticorpo policlonal antiFlt-1 (Santa Cruz sc 316) diluído 1:500. A) Região interlobular de um feto de 65 dias. B) Região interlobular de um animal de 5 meses. C) JCM de um feto de 111 dias. D) JCM de um animal de 2 anos de idade. Legenda: $\uparrow$, Célula endotelial; > célula migratória; $\rightarrow$, célula epitelial tímica. Barras: $50 \mu \mathrm{m}$ 


\subsubsection{Imunolocalização do KDR}

Assim como a proteína do VEGF e Flt-1, a proteína do KDR foi identificada no timo suíno de todos os grupos experimentais, pré e pós-natais (Figuras 12, 13 e 14). De acordo com a idade também observamos variação da sua expressão em determinadas células do órgão, porém novamente os animais dos grupos pós-natais apresentaram imunomarcação mais rara nos diversos tipos celulares do órgão.

Imunomarcação foi observada nas CETc da RS dos animais de todos os grupos pré-natais (Figura 12-A, C e E). Nos grupos pós-natais, foram raras as CETc imunomarcadas nos animais de 5 meses (Figura 13-A), enquanto que nenhuma marcação foi observada nestas células nos animais 2 anos de idade (Figura 13-C).

CETm apresentaram imunomarcação nos animais de todos os grupos prénatais, especialmente nos animais de 65 dias (Figura 12-B). Nos grupos pós-natais, raras CETm imunomarcadas, geralmente próximas a CTs, foram observadas nos animais de 5 meses (Figura 13-C), enquanto que nenhuma CETm imunomarcada foi observada nos animais de 2 anos de idade (Figura 13-D).

Imunomarcação em CMs foi observada em todos os grupos pré e pós-natais, mas muito mais raramente nestes últimos. CMs imunomarcadas foram identificadas por todo o córtex, mas especialmente na RS, próximas a septos e vasos sanguíneos (Figura 12-C e Figura 14-D). Tais células também foram observadas próximas a vasos da JCM (Figura 14-A e C) e regiões interlobulares (Figura 13-C e Figura 14$B$ ), assim como na região mais central da medula, quando próximas a CTs (Figura 12-D e Figura 13-B) e vasos sanguíneos (Figura 12-F).

Os CTs apresentaram imunomarcação nos animais de todas as fases pré (Figura 12-A, D e F) e pós-natais (Figura 13-B e D).

CEs imunomarcadas foram observadas nos animais de 65 e 85 dias de idade gestacional, especialmente em vasos sanguíneos da JCM e medula (Figura 12-B e Figura 13-F). Raras CEs imunomarcadas foram observadas nos animais de 111 dias, enquanto que ausência de imunomarcação nestas células foi observada nos grupos pós-natais (Figura 13-A e Figura 14-D). 
Nos grupos pré-natais, constituídos de machos e fêmeas, não observamos qualquer diferença entre os sexos. 


\section{Córtex}
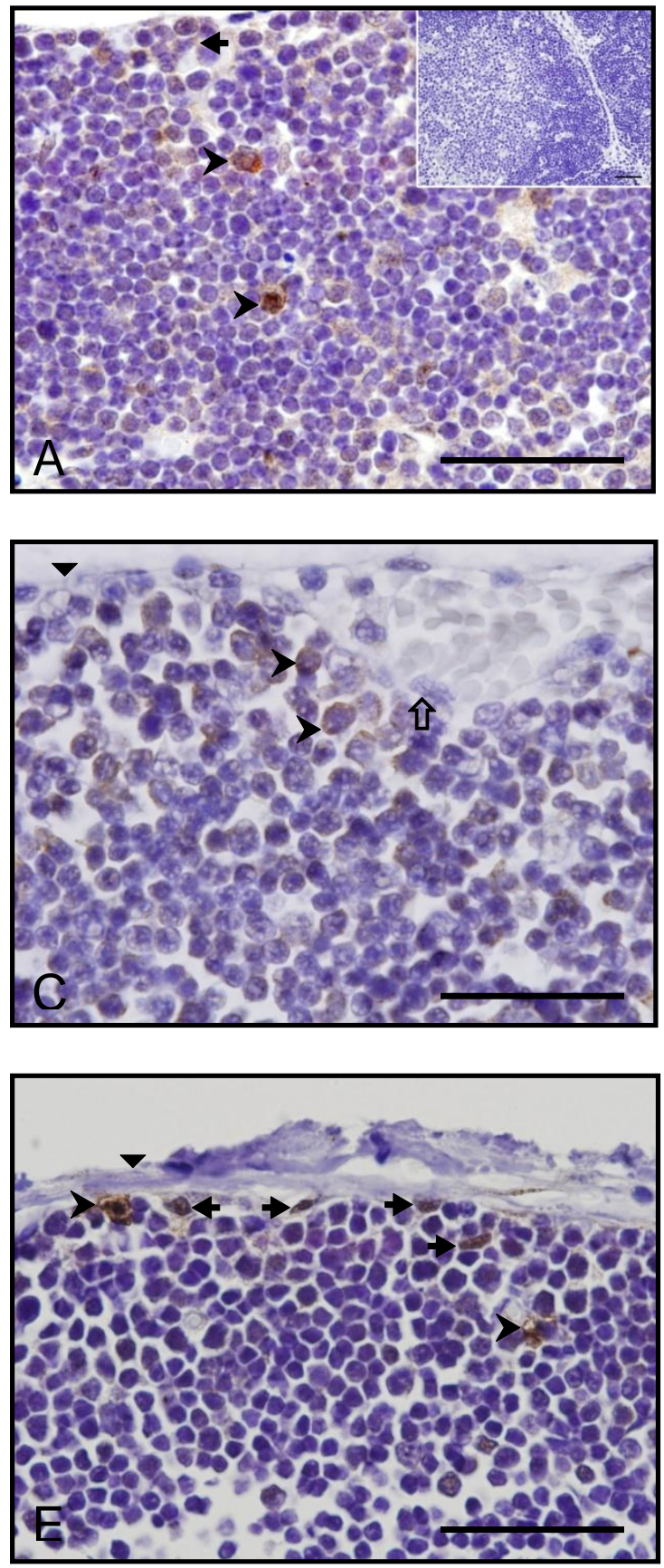

Medula
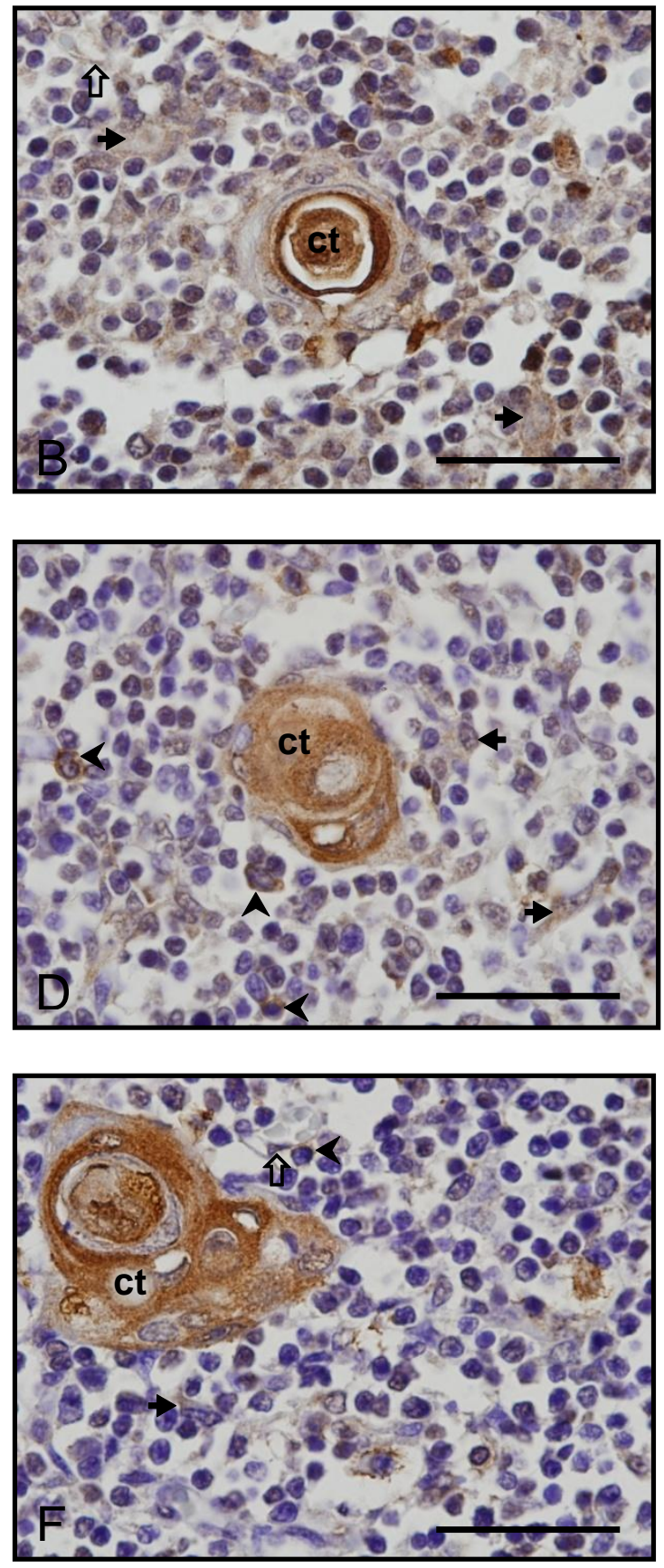

Figura $12(\mathrm{~A}-\mathrm{F})$ - Fotomicrografias da expressão da proteína KDR no timo suíno. Reação imuno-histoquímica realizada com anticorpo policlonal antiKDR (Santa Cruz sc 315) diluído 1:500. Amostras dos grupos prénatais: 65 (A e B), 85 (C e D) e 111 (E e F) dias de gestação. Legenda: ct, corpúsculo tímico; $>$, célula migratória; 仓, célula endotelial; $\nabla$, cápsula; $\rightarrow$, célula epitelial tímica. Inserção: controle negativo (vale para as figuras 13 e 14). Barras: $50 \mu \mathrm{m}$ 


\section{Córtex}
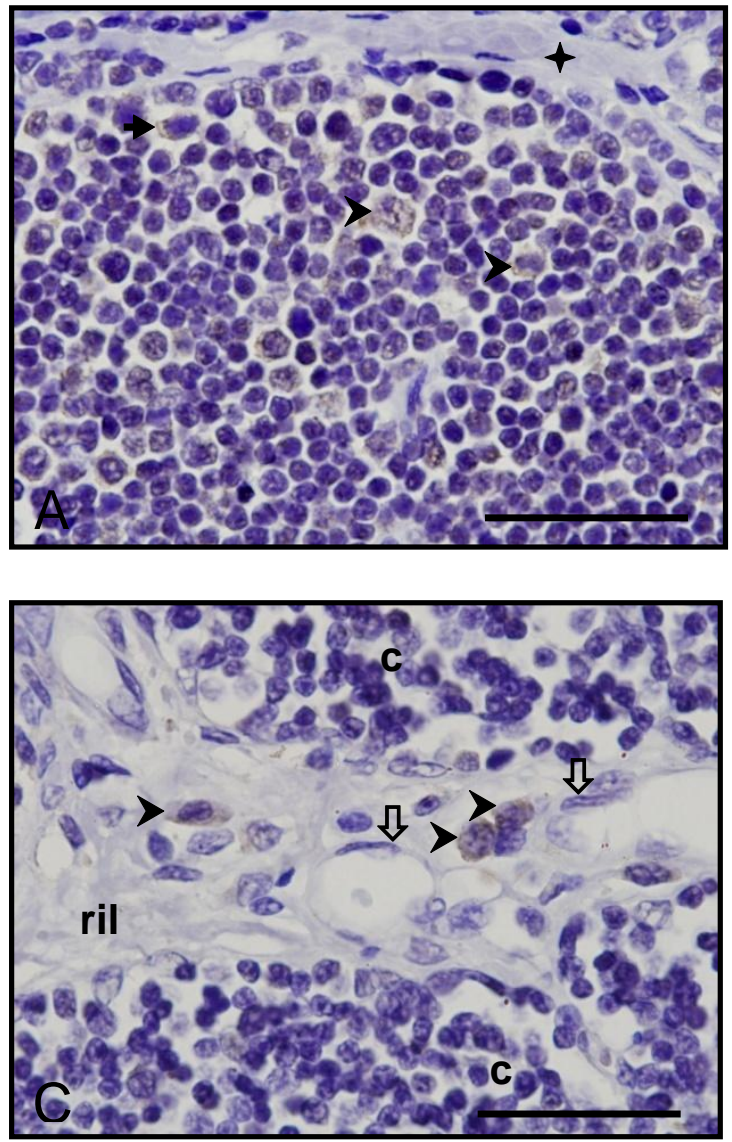

Medula
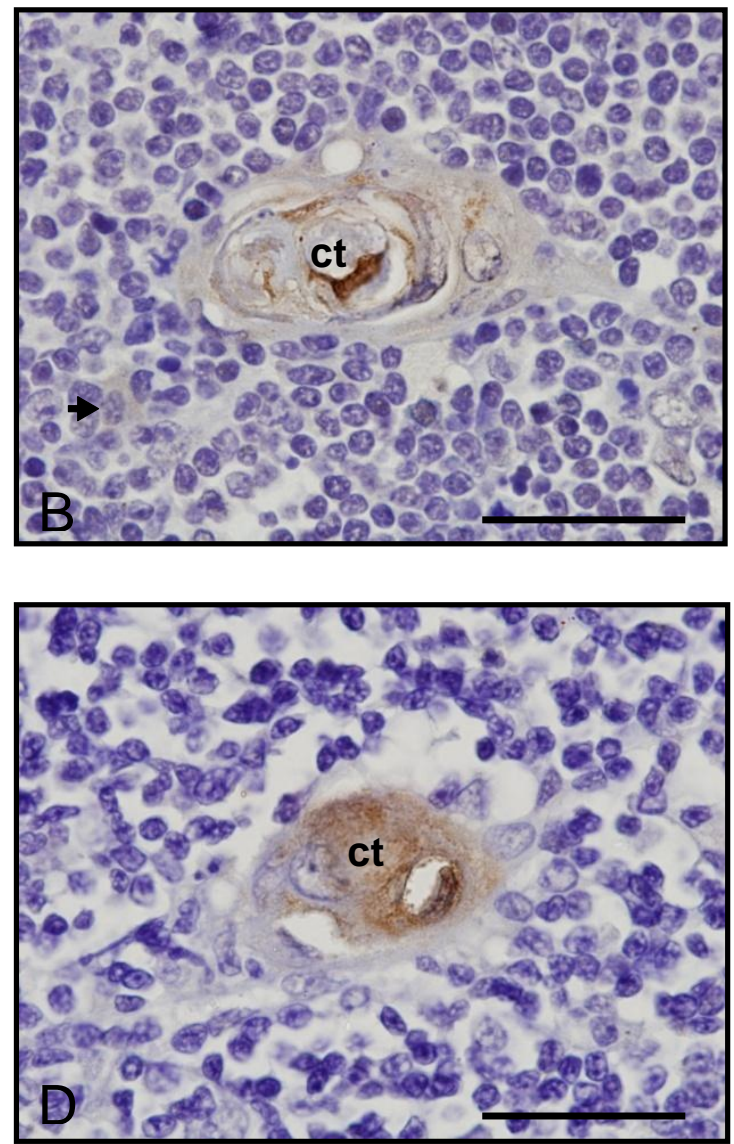

Figura $13(A-D)$ - Fotomicrografias da expressão da proteína KDR no timo suíno. Reação imuno-histoquímica realizada com anticorpo policlonal antiKDR (Santa Cruz sc 315) diluído 1:500. Amostras dos grupos pósnatais: 5 meses (A e B) e 2 anos de idade (C e $\mathbf{D})$. Legenda: $\mathbf{c}$, córtex; ct, corpúsculo tímico; ril, região interlobular; $\boldsymbol{+}$, septo; $\boldsymbol{\rangle}$, célula migratória com imunomarcação em região interlobular; 仓) célula endotelial; $\rightarrow$, célula epitelial tímica. Barras: $50 \mu \mathrm{m}$ 

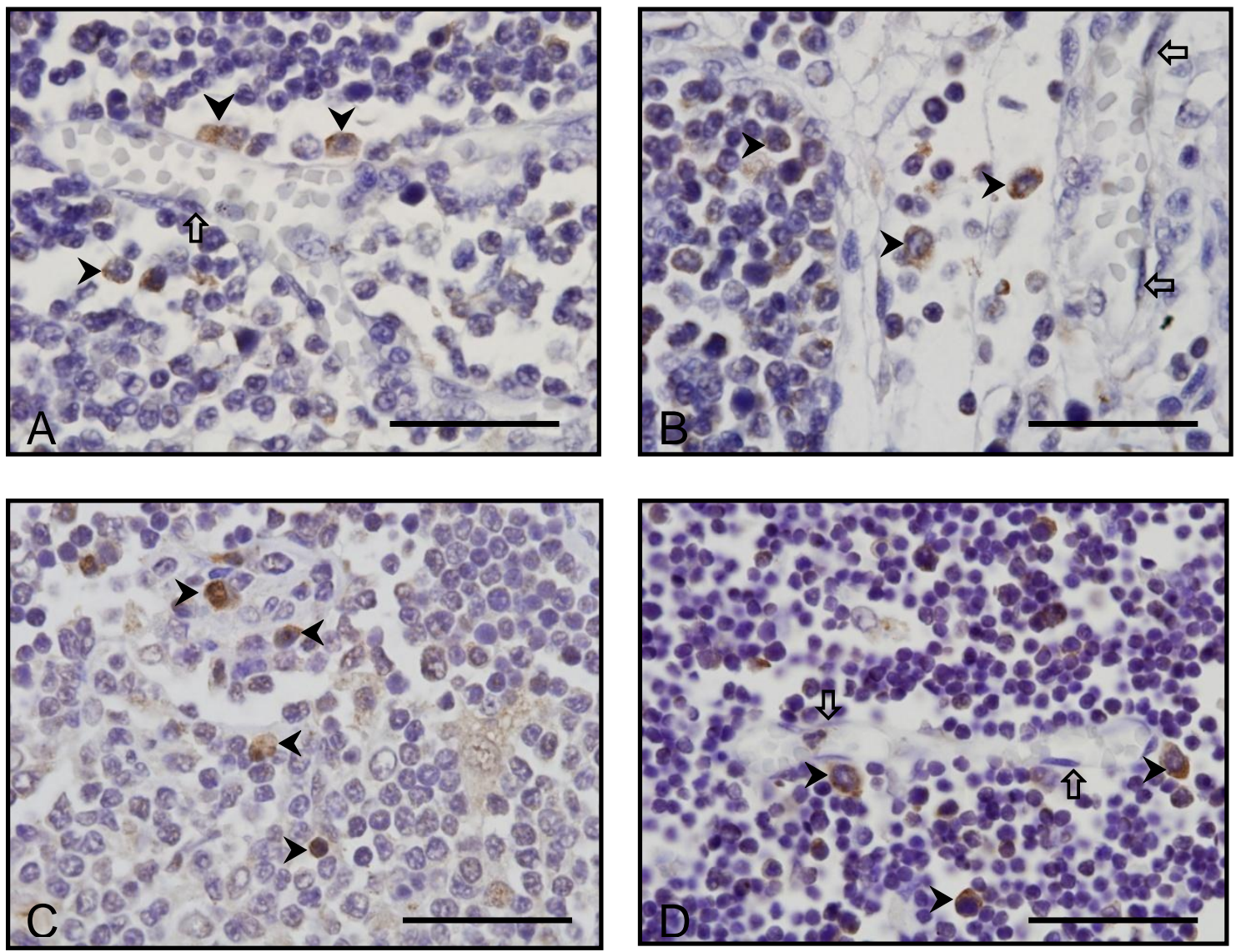

Figura $14(A-D)$ - Fotomicrografias da expressão da proteína KDR no timo suíno. Reação imuno-histoquímica realizada com anticorpo policlonal antiKDR (Santa Cruz sc 315) diluído 1:500. A) JCM de um feto de 85 dias. B) Região interlobular de um feto de 85 dias. C) JCM de um animal de 5 meses. D) Córtex de um animal de 5 meses. Legenda: $>$, célula migratória; 亿, célula endotelial. Barras: $50 \mu \mathrm{m}$ 


\subsection{RELAÇÃO ENTRE A EXPRESSÃO GÊNICA TEMPORAL DO VEGF E SEUS RECEPTORES (Flt-1 E KDR) E AS VARIÁVEIS V Vivaso,timo], S S vivaso,timo] $E$ $L_{v[v a s o, t i m o]}$ NO CÓRTEX E JUNÇÃO CORTICOMEDULAR}

Por serem parâmetros quantificáveis, as variáveis estereológicas relativas à vascularização foram correlacionadas à expressão gênica do VEGF e seus receptores (FIt-1 e KDR) (Gráficos 5, 6 e 7), também diretamente relacionados à vascularização do órgão. Observamos que existe um padrão que se repete no córtex e na JCM para as três variáveis estereológicas estimadas ao longo do desenvolvimento e involução do timo: no córtex diminuem gradativamente e na JCM apresentam valores mais elevados nos timos dos animais de 111 dias de gestação. A expressão do mRNA do VEGF e do seu receptor Flt-1 correlacionou-se negativamente às variáveis $\mathrm{V}_{\mathrm{v}[\text { vasos,timo], }} \mathrm{S}_{\mathrm{v} \text { [vasos,timo] }}$ e $\mathrm{L}_{\mathrm{v}[\text { vasos,timo], tanto no córtex como }}$ na JCM; todas as correlações negativas significativas $(p<0,05)$ podem ser observadas na Tabela 9. Já o KDR apresentou correlação positiva com as três variáveis estereológicas estudadas, porém de forma não significativa (Tabela 9). É interessante notar que a expressão do mRNA do VEGF correlacionou-se de maneira negativa principalmente com a vascularização do córtex e o Flt-1 com a vascularização da JCM. Este padrão não foi observado para o KDR.

Como não realizamos a quantificação da expressão protéica do VEGF e de seus receptores estudados (Flt-1 e KDR), não pudemos analisar se existe ou não correlação entre esta expressão e os valores das densidades estereológicas referentes à vascularização. Porém, qualitativamente podemos afirmar que a expressão protéica acompanha a vascularização do córtex, diminuindo gradativamente com o decorrer da idade. 


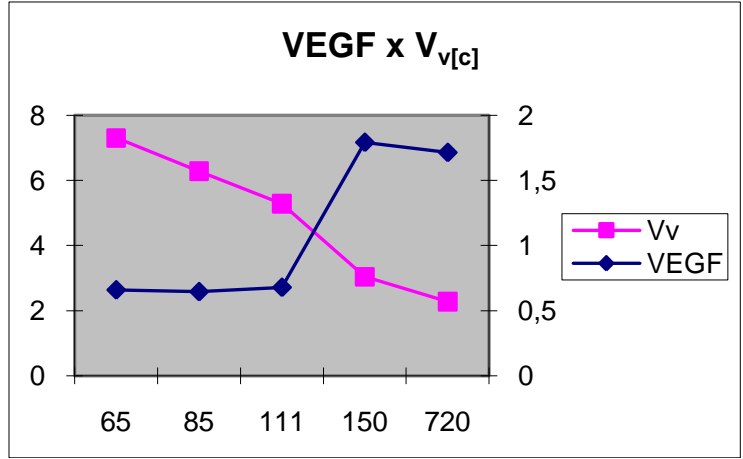

A
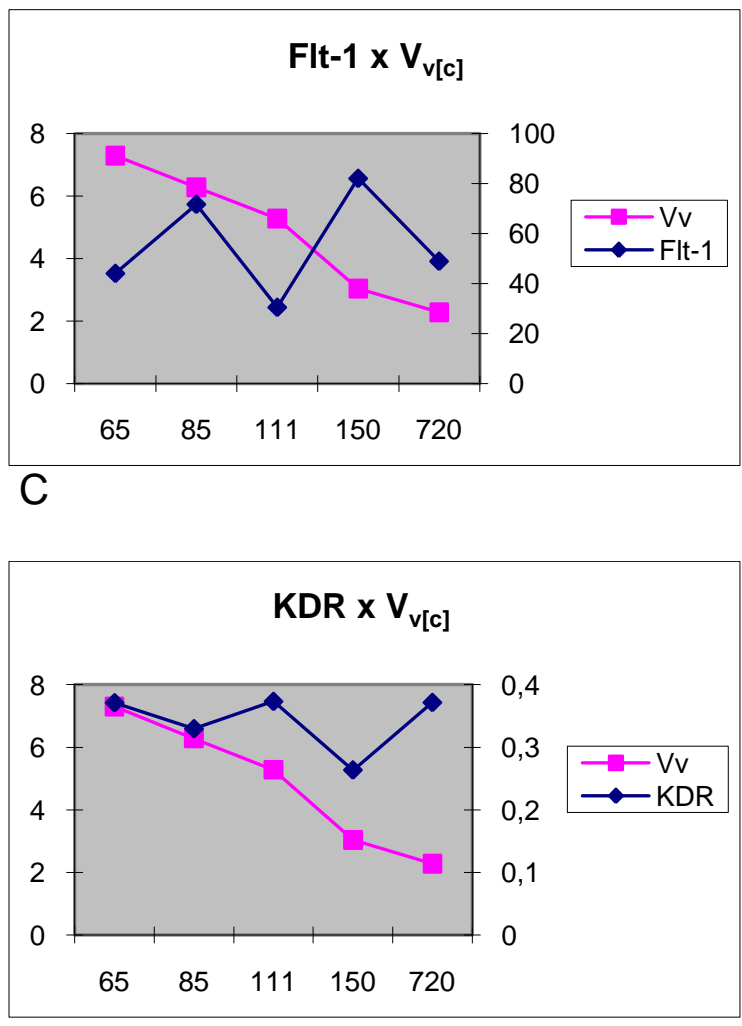

$\mathrm{E}$

Gráfico $5(\mathrm{~A}-\mathrm{F})$ - Relação entre a expressão gênica temporal do VEGF e seus receptores (FIt-1 e KDR) e a variável estereológica densidade de volume vascular no córtex $\left(\mathrm{V}_{\mathrm{v}[\mathrm{c}]}\right)$ e na junção corticomedular $\left(\mathrm{V}_{\mathrm{v}[\mathrm{m}]}\right)$ do timo de suínos em idades pré-natais (65, 85 e 111 dias) e pós-natais de 5 meses (150 dias) e 2 anos (720 dias) de idade

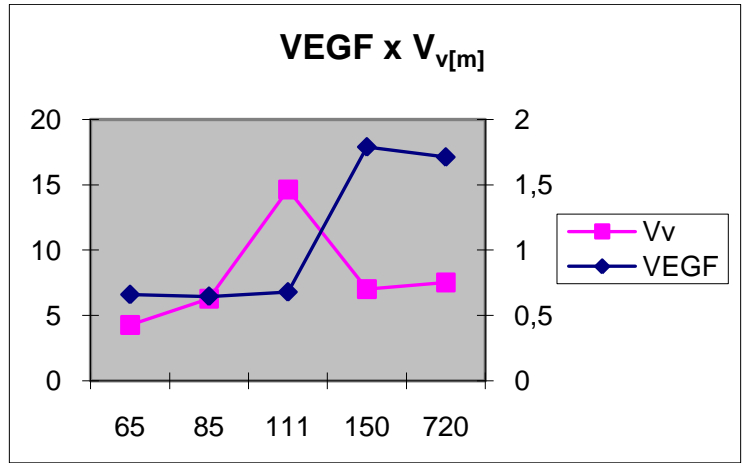

B
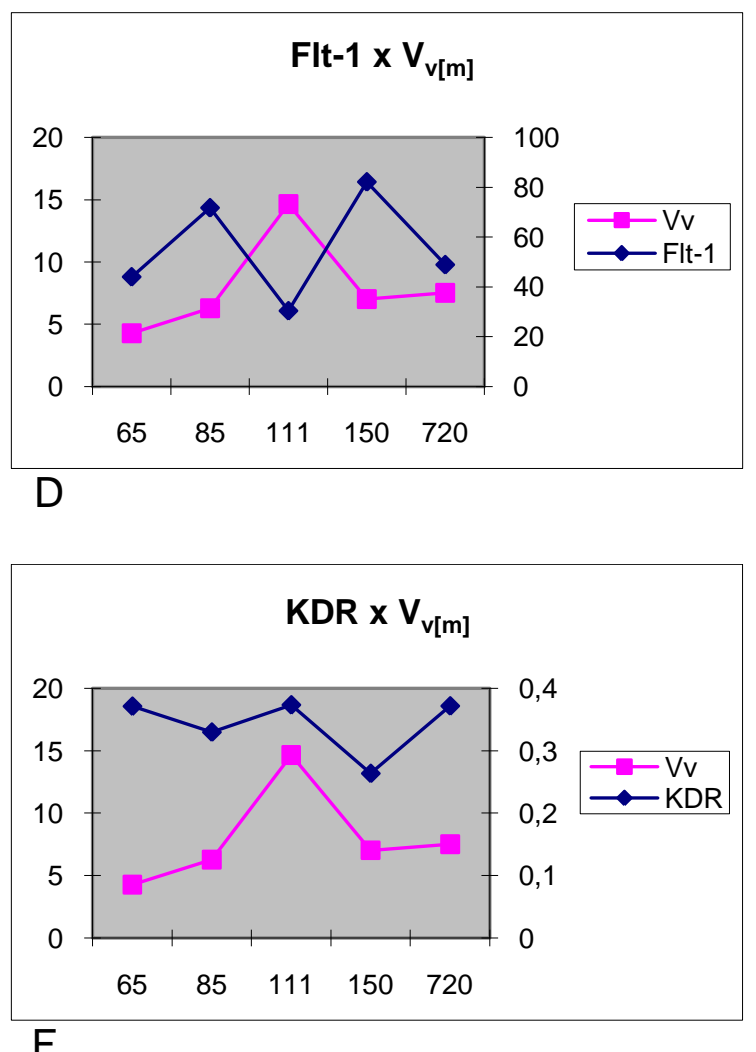

$\mathrm{F}$ 


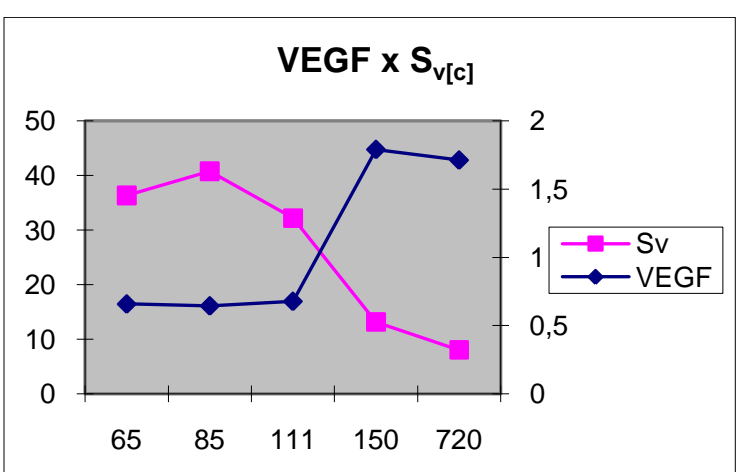

A

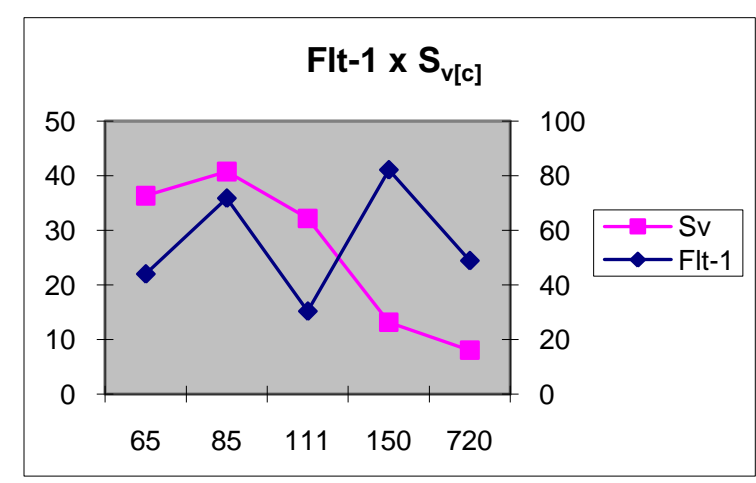

C

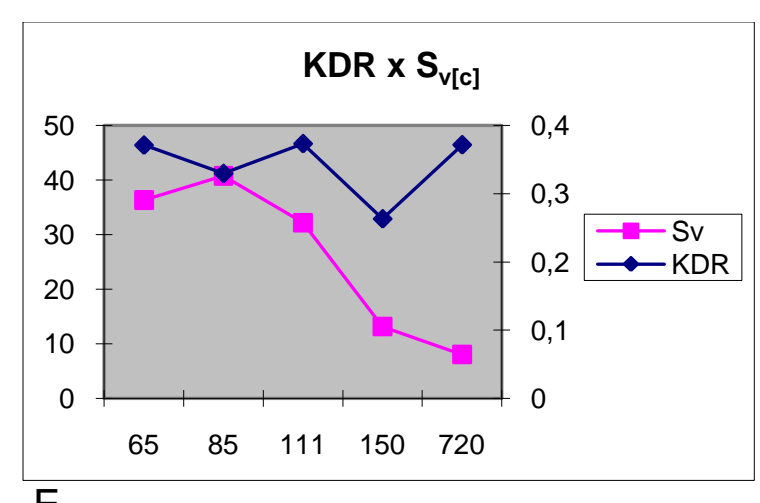

$\mathrm{E}$

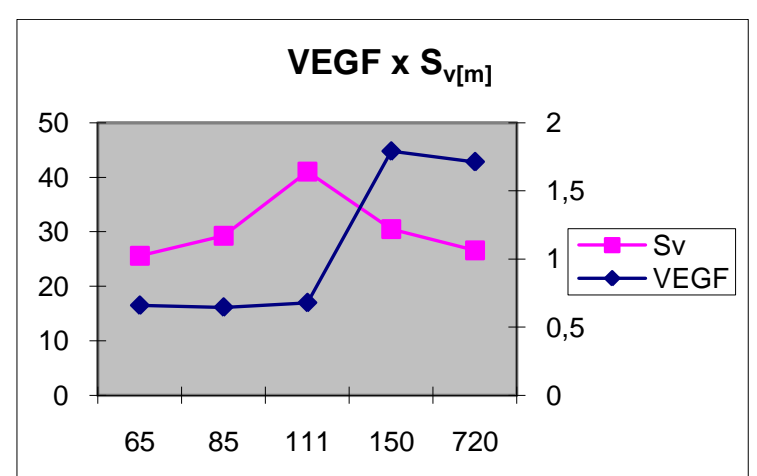

B

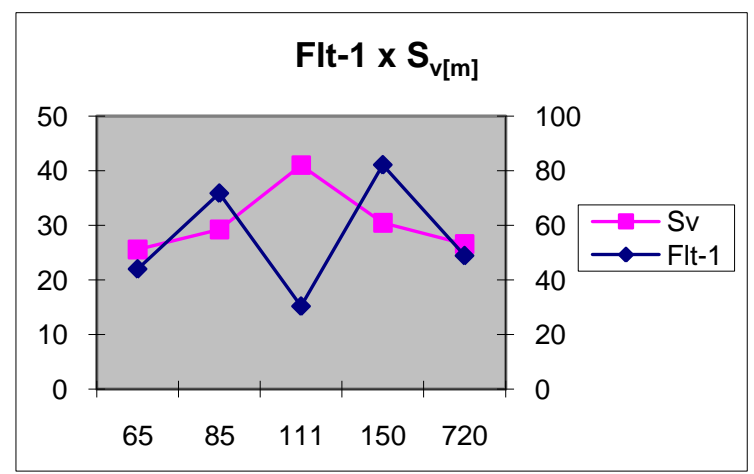

D

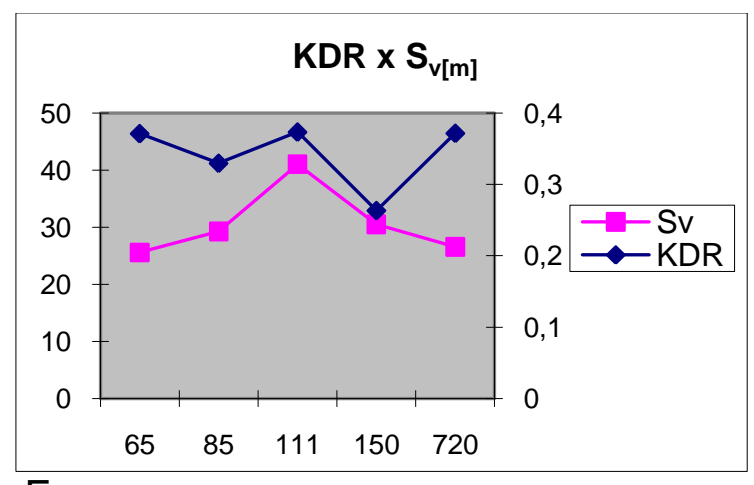

$\mathrm{F}$

Gráfico 6 (A-F) - Relação entre a expressão gênica temporal do VEGF e seus receptores (Flt-1 e KDR) e a variável estereológica densidade de área vascular no córtex $\left(S_{v[c]}\right)$ e na junção corticomedular $\left(S_{v[m]}\right)$ do timo de suínos em idades pré-natais (65, 85 e 111 dias) e pós-natais de 5 meses (150 dias) e 2 anos (720 dias) de idade 


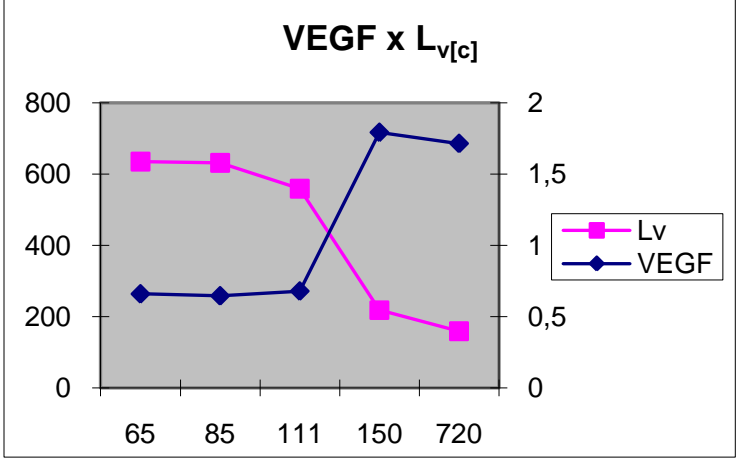

A

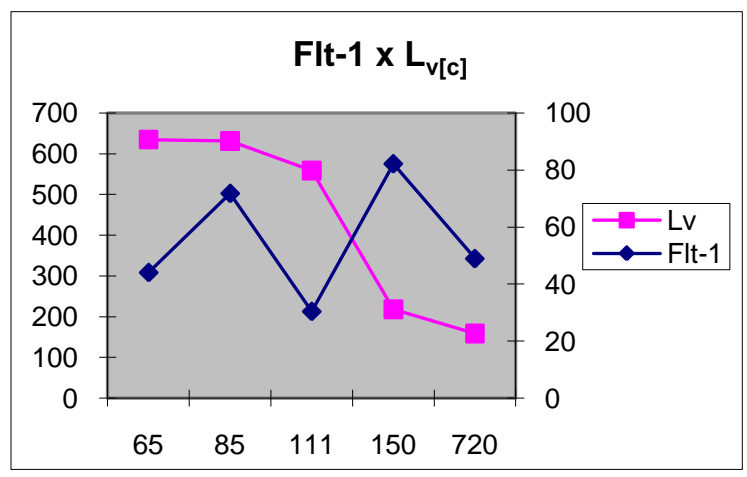

C

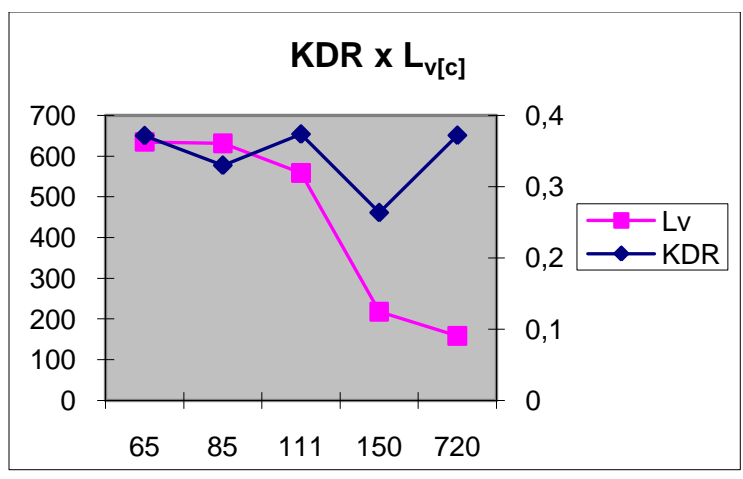

$\mathrm{E}$

Gráfico 7 (A-F) - Relação entre a expressão gênica temporal do VEGF e seus receptores (Flt-1 e KDR) e a variável estereológica densidade de comprimento vascular no córtex $\left(L_{v[c]}\right)$ e na junção corticomedular $\left(L_{v[m]}\right)$ do timo de suínos em idades pré-natais $(65,85$ e 111 dias) e pós-natais de 5 meses (150 dias) e 2 anos (720 dias) de idade

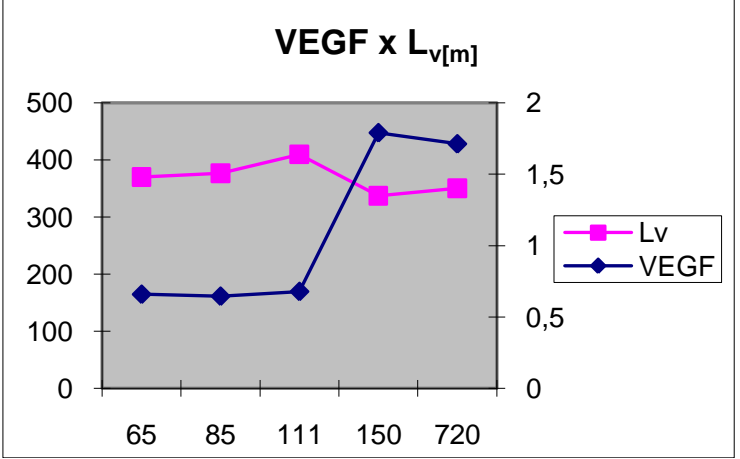

B

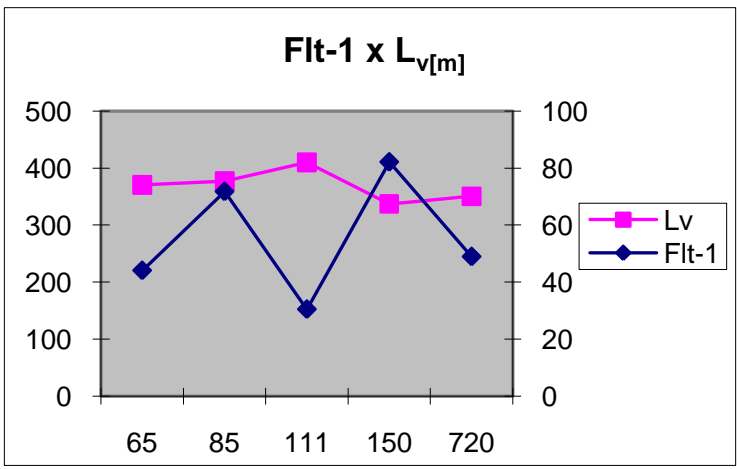

D

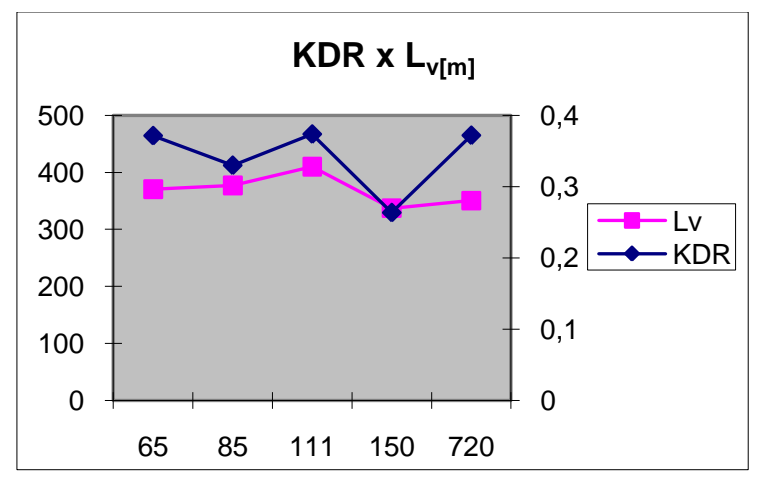

F 
Tabela 9 - Correlação entre as variáveis estereológicas e a expressão gênica do sistema VEGF-A

\begin{tabular}{|c|c|c|c|c|c|c|c|c|c|}
\hline & $\mathrm{L}_{\mathrm{v}[\mathrm{c}]}$ & $\mathrm{L}_{\mathrm{v}[\mathrm{m}]}$ & $\mathrm{S}_{\mathrm{v}[\mathrm{c}]}$ & $\mathrm{S}_{\mathrm{v}[\mathrm{m}]}$ & $\mathrm{V}_{\mathrm{v}[\mathrm{c}]}$ & $\mathbf{V}_{\mathrm{v}[\mathrm{m}]}$ & VEGF & Flt-1 & KDR \\
\hline$L_{v[c]}$ & 0 & & & & & & & & \\
\hline$L_{v[m]}$ & $\begin{array}{c}r=0,72 \\
(0,1624)\end{array}$ & 0 & & & & & & & \\
\hline$S_{v[c]}$ & $\begin{array}{l}r=0,99 \\
(0,005)^{*}\end{array}$ & $\begin{array}{l}r=0,69 \\
(0,1946)\end{array}$ & 0 & & & & & & \\
\hline $\mathbf{S}_{\mathrm{v}[\mathrm{m}]}$ & $\begin{array}{l}r=0,20 \\
(0,7442)\end{array}$ & $\begin{array}{l}r=0,71 \\
(0,1768)\end{array}$ & $\begin{array}{l}r=0,18 \\
(0,7655)\end{array}$ & 0 & & & & & \\
\hline $\mathrm{V}_{\mathrm{V}[\mathrm{c}]}$ & $\begin{array}{l}r=0,97 \\
(0,005)^{*}\end{array}$ & $\begin{array}{l}r=0,57 \\
(0,3058)\end{array}$ & $\begin{array}{c}r=0,95 \\
(0,0115)^{*}\end{array}$ & $\begin{array}{l}r=0,01 \\
(0,9801)\end{array}$ & 0 & & & & \\
\hline$V_{v[m]}$ & $\begin{array}{l}r=0,02 \\
(0,9698)\end{array}$ & $\begin{array}{l}r=0,67 \\
(0,2160)\end{array}$ & $\begin{array}{c}r=-0,006 \\
(0,9914)\end{array}$ & $\begin{array}{c}r=0,95 \\
(0,0132)^{*}\end{array}$ & $\begin{array}{l}r=-0,47 \\
(0,4170)\end{array}$ & 0 & & & \\
\hline VEGF & $\begin{array}{c}r=-0,98 \\
(0,002)^{*}\end{array}$ & $\begin{array}{l}r=-0,82 \\
(0,0875)\end{array}$ & $\begin{array}{c}r=-0,96 \\
(0,01)^{*}\end{array}$ & $\begin{array}{l}r=-0,27 \\
(0,6489)\end{array}$ & $\begin{array}{l}r=-0,54 \\
(0,3369)\end{array}$ & $\begin{array}{l}r=-0,14 \\
(0,8186)\end{array}$ & 0 & & \\
\hline Flt-1 & $\begin{array}{l}r=-0,31 \\
(0,6077)\end{array}$ & $\begin{array}{l}r=-0,69 \\
(0,1899)\end{array}$ & $\begin{array}{l}r=-0,20 \\
(0,7361)\end{array}$ & $\begin{array}{l}r=-0,39 \\
(0,5163)\end{array}$ & $\begin{array}{l}r=-0,31 \\
(0,6083)\end{array}$ & $\begin{array}{l}r=-0,52 \\
(0,3622)\end{array}$ & $\begin{array}{l}r=0,44 \\
(0,4494)\end{array}$ & 0 & \\
\hline KDR & $\begin{array}{l}r=0,36 \\
(0,5470)\end{array}$ & $\begin{array}{l}r=0,59 \\
(0,2856)\end{array}$ & $\begin{array}{l}r=0,28 \\
(0,6429)\end{array}$ & $\begin{array}{l}r=0,07 \\
(0,9051)\end{array}$ & $\begin{array}{l}r=0,36 \\
(0,5478)\end{array}$ & $\begin{array}{l}r=0,24 \\
(0,6911)\end{array}$ & $\begin{array}{l}r=-0,49 \\
(0,3942)\end{array}$ & $\begin{array}{c}r=-0,90 \\
(0,05)^{*}\end{array}$ & 0 \\
\hline
\end{tabular}

r, razão; *diferença estatisticamente significativa 
DISCUSSÃO 


\section{DISCUSSÃO}

Ao considerarmos a relevância da anatomia do timo para o entendimento dos diferentes fenômenos que the são peculiares, julgamos pertinente incluirmos nesta discussão alguns aspectos referentes às nossas observações sobre a morfologia do órgão, bem como algumas considerações sobre a sua nomenclatura, na intenção de esclarecer pontos e permitir uma análise comparativa em relação a outros trabalhos.

\subsection{MORFOLOGIA DO TIMO SUÍNO}

Diferenças importantes nos padrões morfológicos, topográficos ou sintópicos já estabelecidos para o timo da espécie estudada não foram observadas durante a dissecção para coleta do órgão. No entanto, observamos a ausência da porção cranial do lobo cervical direito do timo de $1(6,6 \%)$ dos 15 fetos por nós estudados. Achados similares de ausência de lobos ou partes tímicas foram relatados em estudos de outros autores. Drummond (1996) relatou a ausência de massa tímica no antímero direito de $8(28,5 \%)$ suínos dos 28 animais por ele estudados e a ausência total da parte torácica de 1 (3,3\%) dos 30 animais examinados em estudo anterior. Ausência do lobo torácico direito foi observada por Silva e Gonçalez (1998) em 20\% de um total de 30 animais da raça Pietran por eles estudados. Já Carneiro e Silva et al. (2003), em um estudo com 30 animais da raça Piau, relataram ausência do lobo torácico direito em $10 \%$ das amostras e do lobo torácico esquerdo em 3,3\%, enquanto Gonçalez et al. (2003), ao estudarem 30 fetos da linhagem Rezende, relataram ausência do lobo torácico direito em $30 \%$ dos animais. Consideramos que tais achados possam estar associados a variações raciais e de linhagem, entretanto a variação individual não pode ser descartada, mesmo porque notamos a inexistência de estudos com o objetivo de pesquisar se a ausência de partes tímicas é determinada por fatores genéticos e/ou congênitos, bem como se de fato esta seria uma condição comum na espécie. 
Ainda, sobre a morfologia do órgão, uma observação importante diz respeito à quinta e mais atual edição da Nomina Anatomica Veterinaria (N.A.V.) (INTERNATIONAL COMMITTEE ON VETERINARY GROSS ANATOMICAL NOMENCLATURE, 2005), que abrange o assunto sobre a lobação tímica de maneira generalista, não fazendo qualquer distinção de nomenclatura e organização do órgão entre as espécies domésticas, ao oposto do modo como apresenta outros órgãos lobados como por exemplo os pulmões, fígado e pâncreas. A nomenclatura convencionada pelo comitê responsável por tal publicação compreende 5 lobos tímicos (lobo cervical direito e esquerdo, lobo intermédio e lobo torácico direito e esquerdo), porém, como não há correlações espécie-específicas e é sabido que esta nomenclatura lobar não corresponde à exata lobação do órgão em todas as espécies de animais domésticos. Assim, necessita o leitor se remeter a publicações clássicas em anatomia veterinária para embasar a aplicação dos termos sugeridos às características descritas para o órgão da espécie pesquisada. No entanto, para a espécie suína tal nomenclatura pode ser aplicada integralmente devido a espécie apresentar o timo constituído de todos os lobos por ela listados, o que pudemos constatar em nossas observações, que estão de acordo com as descrições de Schummer et al. (1981), Venzke (1986) e König e Liebich (2002).

\subsection{AMOSTRAGEM EXPERIMENTAL}

As similaridades fisiológicas entre humanos e suínos (MARIANO, 2003; VACKOVA et al., 2007) foi aproveitada no presente estudo especialmente com a intenção de explorar o potencial uso prático da espécie no esclarecimento de eventos importantes, ainda não abordados na literatura, com relação ao desenvolvimento, maturação e involução do timo. Ademais, julgamos que as vantagens da espécie como modelo experimental em estudos temporais e imunológicos facilitam pesquisas que visam o entendimento de mecanismos de controle de expressão gênica e, portanto, de fatores de crescimento relacionados à vascularização. 
Quanto à definição das idades dos animais dos grupos pré-natais utilizados neste experimento, objetivamos abranger os terços inicial, médio e final de desenvolvimento fetal da espécie. De acordo com Patten (1948), na espécie suína a transição entre o fim da fase embrionária e início da fase fetal ocorre por volta do 35을 dia de gestação. Obtivemos animais com esta idade, mas constatamos dificuldades em identificar macroscopicamente o timo, o que inviabilizou a coleta e, portanto, optamos por constituir o primeiro grupo pré-natal com fetos em idade mais avançada. Assim, associamos os dados de Badertscher (1915), que relacionam o comprimento fetal suíno com o estágio de desenvolvimento tímico, aos de Evans e Sack (1973), que estabelecem curvas de crescimento no desenvolvimento pré-natal de diversas espécies domésticas, relacionando o "crown-rump" com a idade gestacional em dias, e consideramos ideal que o primeiro grupo pré-natal fosse coletado ao $65^{\circ}$ dia de desenvolvimento, pois o órgão neste estágio apresenta tamanho adequado para se obter um fragmento de $0,5 \mathrm{~cm}^{3}$, ideal para análises de quantificação relativa da expressão de mRNA por PCR em tempo real.

Utilizamos apenas animais fêmeas nos grupos pós-natais (Grupos 4 e 5) em virtude dos machos destinados ao abate de granjas comerciais serem precocemente castrados, o que pode interferir na função tímica afetando as linhagens de timócitos e o desenvolvimento normal do órgão devido à consequente redução da concentração plasmática dos hormônios esteróides sexuais acarretada com este procedimento, como já demonstrado e relatado por diversos autores (OLSEN et al., 1994; VISELLI et al., 1995; RODEN et al., 2004; REZZANI et al., 2008). Frente aos estudos que demonstram que em ratos e camundongos os efeitos da gonadectomia sobre a função tímica não são permanentes e sim temporários, apesar de prolongados (MIN et al., 2006; PESIC et al., 2007), consideramos que por não haverem estudos similares em suínos, animais gonadectomizados constituiriam uma potencial fonte de viés na amostra. 


\subsection{ASPECTOS HISTOLÓGICOS DO TIMO SUÍNO}

Comparado ao órgão do animal adulto, o timo neonatal murino é dominado pelo córtex, ou seja, há pouca área medular e, além disso, apresenta a junção corticomedular pouco definida. Porém, a transição para o padrão adulto ocorre rapidamente, logo na primeira semana de vida pós-natal (CUDDIHY et al., 2009).

No presente estudo, observamos que o timo suíno pré-natal, a partir de 65 dias de gestação, apresenta grandes áreas medulares e junção corticomedular bem definida, o que difere dos dados em camundongos apresentados por Cuddihy et. al (2009) e encontra fundamentação em relatos de que o timo das espécies domésticas amadurece precocemente em relação ao timo dos roedores, o que implicaria num maior desempenho funcional antes do nascimento (TIZARD, 2000).

Não investigamos o timo de neonatos, mas sim de fetos e animais adultos, o que nos permite afirmar que características similares ao padrão histológico do timo adulto já estão presentes na espécie suína antes mesmo do nascimento, o que nos faz levantar a hipótese de que tal fato pode inferir em diferenças espécie-específicas nos processos de proliferação, maturação e diferenciação de timócitos, assim como em demais eventos relacionados a interações célula-célula no órgão. Por outro lado, concomitantemente observamos uma aparente menor densidade celular nas fases pré-natais em relação aos animais de 5 meses e 2 anos de idade, tanto no córtex, como na medula. Entretanto, tal observação necessita ser confirmada em estudos futuros por meio de métodos que permitam análise de frequência e identificação celular como citometria de fluxo. Cuddihy et al. (2009) utilizaram o método para confirmarem a quantificação realizada por imuno-histoquímica de fluorescência para citoqueratinas $\mathrm{K} 5$ e K8, expressas por CETm e CETc, respectivamente. A fenotipagem de timócitos, CETs e demais células presentes no órgão, como as células de linhagem leucocitária, também seria de grande utilidade, pois no presente estudo constatamos dificuldades na precisa identificação destas células quando expressaram a proteína do VEGF e de seus receptores Flt-1 e KDR. 


\subsection{A EXPRESSÃO DO SISTEMA VEGF-A E A VASCULARIZAÇÃO TÍMICA}

O timo promove a diferenciação e a seleção de precursores de células $T$ originadas da medula óssea, sob um processo denominado timopoiese. A diferenciação de células $T$ compreende vários estágios de rearranjo genético, proliferação, morte celular seletiva e expressão diferencial de moléculas de superfície (LEPOSAVIĆ; PERIŠIĆ, 2008).

O papel do sistema VEGF-A no timo á abrangente, compreendendo uma atuação que vai desde a formação vascular até a modulação da maturação linfocitária. Neste contexto, Cuddihy et al. (2009) relatam que camundongos neonatos apresentam uma densa e imatura rede vascular VEGF-dependente que consiste de finos ramos capilares, poucos pericitos e altos níveis endoteliais de $\mathrm{CD} 1^{+}$, um marcador de adesão celular; relatam ainda que a inibição da sinalização do VEGF durante o período neonatal resulta na perda da densa rede capilar tímica e acentuada redução da timopoiese. Já Cimpeam et al. (2008) afirmam que o desenvolvimento da rede vascular do timo é dependente de altas concentrações de VEGF nas CETs. Corbel et al. (2007) e Gabrilovich et al. (1998) ressaltam o papel do VEGF na maturação e diferenciação linfocitária, além da importância na interação entre as células dendríticas apresentadoras de antígeno e os linfócitos. É de consenso comum que tanto as CETc como as CETm apresentam papéis específicos no direcionamento de timócitos à maturação, diferenciação e sobrevivência. Por outro lado, a presença dos timócitos também exerce influência no desenvolvimento e sobrevivência das CETs, e os mecanismos moleculares envolvidos nesta interação podem envolver o VEGF (CORBEL et al., 2007) apesar de serem em grande parte desconhecidos (VAN EWIJK et al., 2000; CUDDIHY et al., 2009).

No presente estudo, as descrições de localização das proteínas do VEGF e seus receptores Flt-1 e KDR foram procedidas com base na observação das mesmas tanto em células estromais como em células hematopoiéticas, embora não tenham sido realizadas técnicas de dupla marcação durante o processamento das amostras, o que possibilitaria a precisa identificação de tipos e subtipos celulares. Células da linhagem leucocitária representaram particular dificuldade de 
identificação. Apesar disso, essa limitação não nos impediu de identificarmos timócitos e CETs, que constituíram a base de nossas inferências sobre a expressão protéica do sistema VEGF-A no timo suíno pré e pós-natal.

Frente ao exposto e de acordo com nossos resultados, a localização dos receptores do VEGF em timócitos indica que o VEGF apresenta um papel direto na função destas células. Corbel et al. (2007) localizou ainda o receptor neurofilina 1 (NP1) em células tímicas concentradas na região subcapsular, receptor este também descrito como mediador das ações do VEGF-A 165 e 121 (SOKER et al., 1998); a junção corticomedular apresentou imunomarcação para o NP1, porém de forma menos evidente. No trabalho destes autores a proteína do VEGF não foi encontrada em linfócitos, apenas em células estromais, o que pode ser devido às condições de cultivo celular às quais as células foram submetidas antes da análise (DAS et al., 2009). Os autores sugerem que a interação entre as células do estroma e os linfócitos aconteça via VEGF que, depois de produzidos pelo estroma tímico, se ligam aos receptores NP1 de algumas populações de linfócitos. Outros autores ainda sugerem a possibilidade da ligação do VEGF diretamente a algumas populações de linfócitos que expressam a proteína do KDR (Cuddihy et al., 2009). Ademais, sabe-se que os receptores NP1 também aumentam a capacidade de ligação do VEGF ao seu receptor KDR (SOKER et al., 1998), o que implicaria em uma ação sinérgica no tecido tímico. A migração dos timócitos DN para marcadores como CD4 e CD8, que nesta condição são timócitos em fase inicial de diferenciação, encontrados comumente na região subcapsular, depende de sinais advindos de regiões do córtex (PROCKOP; PETRIE, 2000). A imunomarcação para VEGF descrita no presente trabalho aponta para a maior expressão desta proteína na região subcapsular do córtex dos timos fetais, especialmente na idade de 65 dias. 0 trabalho de Corbel et al. (2007) também relata a localização dos receptores NP1 na mesma região, corroborando com nossa hipótese de ação sinérgica entre as proteínas.

A expressão protéica do VEGF e seus receptores Flt-1 e KDR foi observada em CETm e corpúsculos tímicos de todas as idades gestacionais estudadas. Entretanto, nos grupos pós-natais observamos que a imunomarcação em CETm foi rara e, quando presente, estas células encontravam-se próximas a corpúsculos 
tímicos. Estes, por sua vez, tanto nos animais de 5 meses como nos animais de 2 anos de idade, apresentaram-se sempre imunomarcados para VEGF, Flt-1 e KDR. Cimpean et al. (2008), observaram imunomarcação para VEGF e seus receptores Flt-1 e KDR em corpúsculos tímicos de 100\% das amostras de um total de 17 timos humanos de indivíduos com idades que variaram de 1 mês a 50 anos de vida, em condições fisiológicas normais e patológicas. Os referidos autores afirmam que, em condições normais, após o nascimento a expressão de VEGF diminui rapidamente e que a imunomarcação de corpúsculos tímicos para este fator de crescimento e seus receptores suporta a hipótese de que os corpúsculos tímicos são estruturas ativas no processo de maturação e seleção de linfócitos no período pós-natal (WATANABE et al., 2005). Nossos resultados revelam que a expressão protéica do sistema VEGF-A do timo suíno pós-natal se assemelha aos achados de Cimpean et al. (2008) em humanos, o que corrobora com a hipótese de participação ativa dos corpúsculos tímicos na timopoiese.

Timócitos CD4 e CD8 DN presentes no córtex expressam VEGF quando em processo de maturação (CUDDIHY et al., 2009), sendo que o timo murino em período neonatal expressa mais VEGF do que timos de animais adultos, relação também observada entre os timos suínos pré e pós-natais do presente estudo. É possível que exista uma modificação das populações celulares que expressam VEGF e seus receptores no timo após o nascimento, no entanto, estudos específicos utilizando dupla marcação ainda não foram realizados e não é possível realizar tal inferência com precisão por meio de análise histológica, conforme comentado anteriormente, também em relação ao presente trabalho. No entanto, alguns autores hipotetizam que a timopoiese seja regulada, via VEGF, tanto pelo compartimento hematopoiético, como pelo compartimento epitelial do timo (OLSSON et al., 2006).

Dockery e Fraher (2007), ao versarem sobre a aplicação da estereologia em estudos vasculares, relatam que uma variedade de descrições numéricas, como análises de fractais e correlações espaciais, vem sendo usada para caracterizar leitos vasculares, porém a estereologia tem sido empregada em um número limitado de áreas que estudam a vascularização. Os mesmos autores alertam para a necessidade da extensão da estereologia em estudos dessa natureza, pois dados 
importantes que a técnica fornece sobre a estrutura espacial biológica, na qual residem informações fisiológicas e moleculares, demonstram o seu potencial de utilidade. De fato, em nosso estudo a correlação das variáveis estereológicas estimadas com os valores da expressão gênica do VEGF e seus receptores KDR e Flt-1 constituiu ferramenta importante na fundamentação de nossas inferências.

Em um estudo temporal quantitativo sobre a vascularização do timo de cães, que abrangeu animais neonatos e em diferentes estágios de desenvolvimento fetal, Agreste (2005) constatou que a vascularização do órgão diminuiu no decorrer do desenvolvimento para aumentar em período próximo ao nascimento, o que corrobora com nossos achados em suínos. Apesar deste estudo em cães ter quantificado a vascularização do órgão sem fazer distinção entre regiões específicas, de modo diferente de como realizamos em nosso experimento, considerando o córtex e a junção corticomedular, esse aumento vascular em proximidade ao nascimento nesta espécie é condizente ao que verificamos para a junção corticomedular do timo suíno, especificamente em relação aos valores das variáveis $S_{v[m]}$ e $V_{v[m]}$. Apesar de não observarmos o mesmo padrão para a variável $L_{v[m]}$, constatamos que os valores da mesma são superiores aos valores da variável $L_{v[c]}$ nos animais de 5 meses e que esse padrão é mantido nos animais de 2 anos de idade. Assim, constatamos que a variável $L_{v[m]}$ supera a variável $L_{v[c]}$ em algum momento entre o final da gestação e os 5 meses de idade, ou seja, ainda em período de intensa atividade tímica.

No presente estudo observamos que no momento no qual as variáveis $\mathrm{S}_{\mathrm{v}[\mathrm{vasos}, \text { timo] }}$ e $\mathrm{V}_{\mathrm{v}[\mathrm{vasos}, \mathrm{timo}}$ apresentaram-se mais altas na junção corticomedular, aos 111 dias de idade gestacional, a expressão do mRNA do KDR no tecido tímico como um todo também foi mais alta. Sabe-se que o KDR é mediador de diversas ações do VEGF como, por exemplo, vasculogênese e angiogênese, permeabilidade vascular, migração e sobrevivência celular (OLSSON et al., 2006). É possível que todas estas ações desencadeadas pelo VEGF, via KDR, estejam acontecendo concomitantemente na junção corticomedular do timo dos fetos aos 111 dias, o que necessita de maior expressão de KDR para que sejam desempenhadas a contento.

A interação VEGF-KDR depende também da presença do outro receptor para VEGF, o Flt-1, que atua regulando a disponibilidade do ligante VEGF-A. 
Normalmente o Flt-1 se liga ao VEGF e impede que o mesmo se ligue ao KDR. A ligação ao KDR inicia uma cascata intracelular de fosforilação dos resíduos de tirosina para culminar nas ações expostas acima.

Observamos que o padrão de expressão do mRNA do Flt-1 é exatamente oposto ao do KDR, ou seja, quando a expressão de um aumenta, a do outro diminui. A correlação de $-0,9 \quad(p<0,05)$ encontrada para as expressões de Flt-1 e KDR corrobora com dados publicados sobre o controle fino da angiogênese, que depende da inter-relação entre os vários receptores e co-receptores do sistema VEGF-A como, por exemplo, as neurofilinas (TAKASHIMA et al., 2002). Esta interdependência já foi observada em estágios iniciais do desenvolvimento murino, quando a ausência total de Flt-1 (Flt-1 $\left.1^{-/-}\right)$causou morte embrionária aos 8,5 dias de gestação por excesso de proliferação das células endoteliais, que acabaram por obliterar o lúmen dos vasos, provavelmente em consequência do aumento de acesso do VEGF-A ao KDR (OLSSON et al., 2006).

Nos períodos estudados ao longo do desenvolvimento e involução do timo suíno, aos 5 meses de idade a expressão do VEGF se apresentou mais elevada e este momento coincide com a mais elevada expressão do Flt-1 e a menor expressão do KDR. Nesta idade, os suínos se encontram próximos à puberdade, período iniciado na espécie em média aos 6 meses de idade (SACK, 1982) e que parece influenciar a função tímica (OLSEN et al., 1994; VISELLI et al., 1995; RODEN et al., 2004; REZZANI et al., 2008). Além disso, esse aumento considerável na expressão do mRNA do VEGF se correlaciona negativamente à fase de diminuição acentuada das variáveis $V_{v[v a s o s, t i m o]}, S_{v[v a s o s, t i m o]}$ e $L_{v[v a s o s, t i m o]}$, o que pode causar hipóxia por diminuição da área de trocas hemato-gasosas no órgão e aumento compensatório de VEGF (GERBER et al., 1997; PUGH; RATCLIFFE, 2003). A hipóxia também induz ajustes de expressão do Flt-1 e KDR (GERBER et al., 1997; OLSZEWSKAPAZDRAK et al., 2009). Além da hipóxia, o próprio VEGF é capaz de induzir aumento ou diminuição de seus receptores (OLSZEWSKA-PAZDRAK et al., 2009).

O timo é um órgão fisiologicamente hipóxico (BRAUN et al., 2001; HALE et al., 2002), que apresenta uma concentração média de $\mathrm{O}_{2}\left(\mathrm{PO}_{2}\right)$ de menos de 10 $\mathrm{mmHg}$, a qual chega a ser, no mínimo, quatro vezes menor que a $\mathrm{PO}_{2}$ do sangue arterial periférico. Os timócitos e células epiteliais apresentam uma adaptação 
peculiar a esta condição hipóxica, que parece ser fundamental para processos fisiológicos tímicos como a seleção, maturação e diferenciação de timócitos (TORRES-ROCA et al., 2000). Genes comumente responsivos à hipóxia como os genes COX-2, HMOX-1 e BNIP3, não são ativados quando células do timo são submetidas a concentrações baixas de $\mathrm{O}_{2}$ (ar ambiente) em relação a concentrações altas (100\%), o que ocorre em qualquer tecido ou linhagem celular exposto a estas condições (HALE et al., 2002). Mesmo diante de um aumento da $\mathrm{PO}_{2}$, as células de diferentes regiões anatômicas do timo não deixam de apresentar reação positiva para pimonidazol (um marcador de células em hipóxia) mesmo quando situadas nas proximidades de vasos sanguíneos, o que indica a ativação de mecanismos intrínsecos de manutenção do estado hipóxico (HALE et al., 2002). Tais mecanismos ainda não foram elucidados, mas os dados do presente estudo apontam para uma regulação temporal da vascularização do timo, o que sugere que o aporte sanguíneo no órgão varie, em acordo com a expressão observada do VEGF e seus receptores KDR e Flt-1, e com os valores estimados das variáveis estereológicas.

A vascularização do timo é feita por artérias que, passando pela cápsula, adentram o órgão e seguem por meio dos seus septos de tecido conjuntivo que o dividem em vários lóbulos. Estas artérias alcançam a junção corticomedular, de onde se ramificam e se direcionam à periferia da camada cortical externa, até próximo à cápsula, para depois retornarem à sua região de origem, formando assim alças que atravessam todo o córtex. As alças vasculares, envoltas por células epiteliais tímicas, compõem a barreira hemato-tímica e impedem em grande parte o acesso de macromoléculas à área de maturação linfocitária (PEARSE, 2006). Quando estas alças chegam à região subcapsular, delineiam vasos de disposição paralela à cápsula, conferindo notável irrigação à região. Este padrão de vascularização cortical determina, provavelmente, o menor grau de hipóxia encontrado na região subcapsular do timo, conforme demonstrado por Hale et al. (2002), e também corrobora com os achados do mesmo estudo que descrevem diferentes graus de $\mathrm{PO}_{2}$ no baço, de acordo com o padrão de sua vascularização.

A condição de baixas tensões de $\mathrm{O}_{2}$ acompanha o timo ao longo de todo seu desenvolvimento e involução; foi demonstrado que tanto camundongos de 4, como de 40 semanas de idade, apresentam os mesmos valores de $\mathrm{PO}_{2}$ (HALE et al., 
2002). Os dados do presente estudo apontam para pouca modificação das variáveis estereológicas relacionadas à vascularização, tanto no córtex como na junção corticomedular, após o nascimento, ou seja, no grupo de 5 meses em relação ao grupo de 2 anos de idade. No entanto, a expressão dos genes dos receptores para VEGF variou entre 5 meses e 2 anos de idade, mas também em relação aos grupos em fases de desenvolvimento fetal.

Sabe-se que a hipóxia é um potente indutor da transcrição do gene do VEGF (GERBER et al., 1997; PUGH; RATCLIFFE, 2003) e do Flt-1 (GERBER et al., 1997) e não modifica a expressão do gene do KDR, apenas influencia na estabilidade de seu mRNA (OLSZEWSKA-PAZDRAK et al., 2009). No presente estudo observamos que no momento em que ocorre uma diminuição significativa dos valores de $V_{v[v a s o s, t i m o]}, S_{v[v a s o s, t i m o]}$ e $L_{v[v a s o s, t i m o]}$, entre o final da gestação (111 dias de idade gestacional) e 5 meses de idade, ocorre também um aumento significativo destes dois genes responsivos à hipóxia, o VEGF e o Flt-1. Ao contrário, como era de se esperar conforme discutido acima em relação ao balanço de expressão entre os receptores do VEGF, o gene do KDR sofre uma regulação negativa aos 5 meses de idade. Estes dados indicam que, apesar de ser um órgão fisiologicamente hipóxico, as células do timo apresentam capacidade de responder a estímulos que diminuem o aporte sanguíneo ao órgão e que, apesar de outros genes que respondem à hipóxia não terem sua expressão modificada (HALE et al., 2002), os genes do VEGF e de seus receptores Flt-1 e KDR apresentam característica diferente no timo suíno.

Se a resposta do sistema VEGF-A à diminuição da vascularização do timo representa uma tentativa de compensar este estado de hipóxia ou se esta resposta é gerada para manutenção do estado hipóxico fisiológico do órgão, estes são aspectos que merecerão atenção em estudos futuros. É interessante ressaltar que a relação observada entre as varáveis $V_{v[v a s o s, t i m o]}, S_{v[v a s o s, t i m o]}$ e $L_{v[v a s o s, t i m o]}$ e a expressão gênica do sistema VEGF-A é negativa para o VEGF e para o Flt-1, mas positiva para o KDR, conforme apresentado na Tabela 9, o que nos permite afirmar que quanto maior a vascularização, e portanto quanto maior a $\mathrm{PO}_{2}$ no timo, menor é a transcrição de VEGF e Flt-1 e maior a transcrição de KDR, o que corrobora com os dados acima e enfatiza a idéia de que o timo desenvolve mecanismos para regular o suprimento de $\mathrm{O}_{2}$ à demanda de suas células in vivo (HALE et al., 2002). 
O que podemos ainda acrescentar no aspecto da manutenção do estado hipóxico no timo, com base nos resultados obtidos, é que apesar da alteração da expressão dos genes, as proteínas codificadas por eles, que efetivamente desempenham ação na manutenção da vascularização pela formação de novos vasos, não apresentam aumento de expressão em acompanhamento ao aumento da expressão gênica.

Comumente encontramos relatos na literatura de que a expressão aumentada do gene do VEGF e de seus receptores é acompanhada de aumento da expressão protéica. No presente estudo, a expressão protéica do sistema VEGF-A, acessada por meio de imuno-histoquímica, se apresentou mais evidente nos timos das fases gestacionais do que nos timos de animais jovens e adultos. Em contraposição, a expressão do mRNA do VEGF e do Flt-1 se apresentou mais elevada após o nascimento, enquanto que a expressão do mRNA do KDR diminuiu aos 5 meses para se elevar novamente aos 2 anos de idade. A meia vida média do mRNA do VEGF é menor do que 1 hora (LEVY et al., 1996). No entanto, em situações de hipóxia sua expressão aumenta de 2 a 3 vezes, devido ao aumento de sua estabilidade (IKEDA et al., 1995).

Como discutido anteriormente, o timo é um órgão que desempenha suas funções em condições de hipóxia relativa e o VEGF e o Flt-1 seriam os genes que responderiam a um desafio de diminuição da quantidade de vasos, sendo esta uma possível causa da diminuição da $\mathrm{PO}_{2}$. Além da regulação transcricional exercida pela hipóxia (SHARKEY et al., 2000), hormônios como o FSH, progesterona e estradiol também modulam a expressão do VEGF (BAUSERO et al., 1998). Sabe-se que o gene do VEGF também é passível de regulação no nível pós-transcricional, o que acontece por meio de ligações com proteínas da família HuR na terminação 3' do gene do VEGF e mesmo sinalização da região 5' para entrada no ribossomo (STEIN et al., 1998), o que aumenta ou diminui a tradução do gene. Assim, quadros de hipóxia, onde normalmente ocorre diminuição de 30 a 50\% do total da tradução, não afetam diretamente a tradução do VEGF, exatamente devido à presença dos mecanismos citados (STEIN et al., 1998). Como no presente estudo a expressão protéica diminuiu drasticamente quando ocorreu diminuição dos valores das variáveis estereológicas, ou seja, nas fases pós-natais, pode-se inferir que esta 
diminuição não seja determinada pela hipóxia, ao contrário do que ocorre com a expressão do gene.

O VEGF também é mediador das relações entre timócitos e células endoteliais, como também das relações entre estas e células do estroma tímico, principalmente no período pós-natal (CUDDIHY et al., 2009).

A vascularização tímica, considerada por estes autores como o terceiro compartimento anatômico do órgão, parece desempenhar função adicional no desenvolvimento tímico, além de sua função clássica de carrear os precursores de linfócitos, oriundos da medula óssea, para o interior do órgão. De acordo com os mesmos autores, expressão reduzida de VEGF nas células epiteliais leva a uma completa alteração do padrão vascular. De fato, a expressão da proteína e do mRNA do sistema VEGF-A no timo suíno, conforme demonstrado e descrito no presente trabalho, não se relaciona apenas às células do endotélio vascular do órgão, podendo inclusive se relacionar negativamente à vascularização. 
CONCLUSÃO 


\section{CONCLUSÃO}

Os resultados deste estudo permitem concluir que:

1) A expressão gênica e protéica do sistema VEGF-A no timo suíno obedece a um padrão temporal e se correlaciona com o desenvolvimento e involução do órgão.

2) A expressão do mRNA do VEGF e seus receptores Flt-1 e KDR é modulada diferentemente durante as fases fetais e nas fases pós-natais estudadas.

3) A expressão protéica do VEGF e seus receptores Flt-1 e KDR em células epiteliais tímicas indica função deste fator como agente modulador destas células e não apenas das células endoteliais do órgão.

4) Ação parácrina e/ou autócrina do VEGF e seus receptores Flt-1 e KDR é indicada no timo suíno.

5) A expressão da proteína do sistema VEGF-A se correlaciona negativamente com aspectos quantitativos da vascularização no timo suíno em período próximo ao nascimento.

6) A progressão da idade após o nascimento se correlaciona negativamente com aspectos quantitativos a vascularização do órgão, mas não com a expressão gênica do sistema VEGF-A, sugerindo resposta do sistema a uma condição hipóxica. 
REFERÊNCIAS 


\section{REFERÊNCIAS}

ACHEN, M. G.; JELTSCH, M.; KUKK, E.; MAKINEN, T.; VITALI, A.; WILKS, A. F.; ALITALO, K.; STACKER, S. A. Vascular endothelial growth factor D (VEGF-D) is a ligand for the tyrosine kinases VEGF receptor 2 (Flk1) and VEGF receptor 3 (Flt4). Proceedings of the National Academy of Sciences of the United States of America, v. 95, n. 2, p. 548-553, 1998.

AGRESTE, F. R. Estudo quantitativo da vascularização do timo em cães. 2005. 118 p. Dissertação (Mestrado em Ciências) - Faculdade de Medicina Veterinária e Zootecnia, Universidade de São Paulo, São Paulo, 2005.

ANDERSEN, B. B.; PAKKENBERG, B. Stereological quantitation in cerebella from people with schizophrenia. Brazilian Journal Psychiatry, v. 182, p. 354-361, 2003.

ANDERSON, M.; ANDERSON, S. K.; FARR, A. G. Thymic vasculature: organizer of the medullary epithelial compartment? International Immunology, v. 12, n. 7, p. 1105-1110, 2000.

APPOLINÁRIO, A. V. M. Vascularização arterial do timo de coelhos (Oryctolagus cuniculus, LINNAEUS, 1758) da raça Nova Zelândia Branco. 1998. 66 p. Dissertação (Mestrado em Ciências) - Faculdade de Medicina Veterinária e Zootecnia, Universidade de São Paulo, São Paulo, 1998.

BADDELEY, A. J.; GUNDERSEN, H. J. G.; CRUZ-ORIVE, L. M. Estimation of surface area from vertical sections. Journal of Microscopy, v. 142, n. 3, p. 259-276, 1986.

BAPTISTA, J. S. Repercussões morfológicas no timo de ratos adultos submetidos à desnutrição protéica e à renutrição precocemente corrigida. 2008. 108 p. Dissertação (Mestrado em Ciências) - Instituto de Ciências Biomédicas, Universidade de São Paulo, São Paulo, 2008.

BARDERTSCHER, J. A. The development of the thymus in the pig: I. Morphogenesis. The American Journal of Anatomy, v. 17, n. 3, p. 317-337, 1915a.

BARDERTSCHER, J. A. The development of the thymus in the pig: II. Histogenesis. The American Journal of Anatomy, v. 17, n. 4, p. 437-493, $1915 \mathrm{~b}$.

BATES, D. O.; HARPER, S. J. Regulation of vascular permeability by vascular endothelial growth factors. Vascular Pharmacology, v. 39, n. 4-5, p. 225-237, 2002. 
BELL, E. T. The development of the thymus. The American Journal of Anatomy, v. 5, p. 29-62, 1905.

BAUSERO, P.; CAVAILLÉ, F.; MÉdURI, G.; FREITAS, S.; PERROT-APPLANAT, M. Paracrine action of vascular endothelial growth factor in the human endometrium: production and target sites, and hormonal regulation. Angiogenesis, v. 2, n. 2, p. 167-182, 1998.

BLACKBURN, C. C.; MANLEY, N. R. Developing a new paradigm for thymus organogenesis. Nature Reviews Immunology, v. 4, p. 278-289. 2004.

BODEY, B.; BODEY JR., B.; SIEGEL S. E.; KAISER H. E. Involution of the mammalian thymus, one of the leading regulators of aging. In Vivo, v. 11, p. 421440, 1997.

BOMBONATO, P. P. Aspectos da morfologia, topografia, e vascularização arterial do timo em fetos de búfalo. 1997. 88 p. Tese (Título de Professor Livre Docente) - Faculdade de Medicina Veterinária e Zootecnia, Universidade de São Paulo, São Paulo, 1997.

BRAUN, R. D.; LANZEN, J. L.; SNYDER, S. A.; DEWHIRST, M. W. Comparison of tumor and normal tissue oxygen tension measurements using OxyLite or microelectrodes in rodents. American Journal of Physiology. Heart and Circulatory Physiology, v. 280, p. 2533-2544, 2001.

BRELINSKA, R.; MALENDOWICZ, L. K.; MALINSKA, A.; KOWALSKA, K. Characteristics of age-related changes in rat thymus: morphometric analysis and epithelial cell network in various thymic compartments. Biogerontology, v. 9, n. 2, p. 93-108, 2008.

BRETAGNE, T. As perspectivas futuras. A genética do futuro será baseada no sangue chinês. Pen Ar Lan ao Vivo - Especial Evolução Genética, n. 10, p. 4, 2009. Disponível em: <http://www.penarlan.com.br/download/ao_Vivo_10-janeiro2009_web.pdf>. Acesso em: 16 fev. 2009.

BUSTARD, L. K.; MCCLELLAN, R. O. Use of pigs in biomedical research. Nature, v. 208, p. 531-535, 1965.

CARNEIRO E SILVA, F. O.; SEVERINO, R. S.; DRUMMOND, S. S.; BOMBONATO, P. P.; BENTO, L. R. T.; MENDES DE LIMA, E. M. Artérias do lobo torácico do timo de sus scrofa da raça Piau. Biotemas, v. 16, n. 1, p. 109-119, 2003.

CASTLE, S. C. Clinical relevance of age-related immune dysfunction. Clinical Infectious Diseases. v. 31, n.2, 578-585, 2000. 
CIMPEAN, A. M.; RAICA, M.; ENCICA, S.; CORNEA, R.; BOCAN, V. Immunohistochemical expression of vascular endothelial growth factor A (VEGF), and its receptors (VEGFR1, 2) in normal and pathologic conditions of the human thymus. Annals of Anatomy, v. 190, n. 3, p. 238-245, 2008.

CORBEL, C.; LEMARCHANDEL, V.; THOMAS-VASLIN, V.; PELUS, A.S.; AGBOTON, C.; ROMÉO, P. H. Neuropilin 1 and CD25 co-regulation during early murine thymic differentiation. Developmental and Comparative Immunology, v. 31, n. 11, p. 1082-1094, 2007.

CUDDIHY, A. R.; GE, S.; ZHU, J.; JANG, J.; CHIDGEY, A.; THURSTON, G.; BOYD, R.; CROOKS, G. M. VEGF-mediated cross-talk within the neonatal murine thymus. Blood, v. 113, n. 12, p. 2723-2731, 2009.

DAS, R. H. J.; VAN OSCH, G. J. V. M.; KREUKNIET, M.; OOSTRA, J.; WEINANS, $\mathrm{H}$.; JAHR, H. Effects of individual control of $\mathrm{pH}$ and hypoxia in chondrocyte culture. Journal of Orthopaedic Research, v. in press, 2009. DOI: 10.1002/jor.20994.

Disponível em:

$<$ http://www3.interscience. wiley.com/user/accessdenied?ID=122627753\&Act=2138\& Code=4717\&Page=/cgi-bin/fulltext/122627753/PDFSTART>. Acesso em: 10 nov. 2009.

DE VRIES, C.; ESCOBEDO, J. A.; UENO, H.; HOUCK, K.; FERRARA, N.; WILLIAMS, L. T. The fms-like tyrosine kinase, a receptor for vascular endothelial growth factor. Science, v. 255, n. 5047, p. 989-991, 1992.

DE WAAL, E. J.; RADEMAKERS, L. H. P. M. Heterogeneity of epithelial cells in the rat thymus. Microscopy Research and Technique, v. 38, p. 227-236, 1997.

DEMIR, R.; KAYISLIA, U. A.; CAYLIA, S.; HUPPERTZ, B. Sequential steps during vasculogenesis and angiogenesis in the very early human placenta. Placenta, v. 27, p. 535-539, 2006.

DEMIR, R.; SEVAL, Y.; HUPPERTZ, B. Vasculogenesis and angiogenesis in the early human placenta. Acta Histochemica, v. 109, p. 257-265, 2007.

DEMIR, R.; YABA, A.; HUPPERTZ, B. Vasculogenesis and angiogenesis in the endometrium during menstrual cycle and implantation. Acta Histochemica, v. in press, 2009. DOI:10.1016/j.acthis.2009.04.004. Disponível em: $<$ http://www.sciencedirect.com/science?_ob=ArticleURL\&_udi=B7CW7-4WD6XS2$1 \&$ _user $=5674931 \&$ _coverDate $=05 \% 2 F 29 \% 2 F 2009 \&$ alid $=1133189958 \&$ rdoc $=8$ \& $\mathrm{fmt}=\mathrm{high} \&$ _orig=search\&_cdi=18099\&_sort=r\&_docanchor $=\&$ view $=\mathrm{c} \&$ _ct $=19 \&$ acct $=$ 
C000049650\&_version=1\&_urlVersion=0\&_userid $=5674931 \&$ md5=72354f7dd93d48 e72616ec514a559256>. Acesso em: 10 jul. 2009.

DOCKERY, P.; FRAHER, J. The quantification of vascular beds: a stereological approach. Experimental and Molecular Pathology, v. 82, p. 110-120, 2007.

DOUEK, D. C.; MCFARLAND, R. D.; KEISER, P. H.; GAGE, E. A.; MASSEY, J. M.; HAYNES, B. F.; POLIS, M. A.; HAASE, A. T.; FEINBERG, M. B.; SULLIVAN, J. L.; JAMIESON, B. D.; ZACK, J. A.; PICKER, L. J.; KOUP, R. A. Changes in thymic function with age and during the treatment of HIV infection. Nature, v. 396, p. 690695, 1998.

DRUMMOND, S. S. Aspectos morfométricos e vascularização arterial do timo em suínos da raça Hampshire. 1996. 57 p. Tese (Doutorado em Ciências) Faculdade de Medicina Veterinária e Zootecnia, Universidade de São Paulo, São Paulo, 1996.

DVORAK, H. F.; SIOUSSAT, T. M.; BROWN, L. F.; BERSE, B.; NAGY, J. A.; SOTREL, A.; MANSEAU, E. J.; VAN DE WATER, L.; SENGER, D. R. Distribution of vascular permeability factor (vascular endothelial growth factor) in tumors: concentration in tumor blood vessels. The Journal of Experimental Medicine, v. 174, n. 5, p. 1275-1278, 1991.

DYCE, K. M.; SACK, W. O.; WENSING, C. J. G. Tratado de anatomia veterinária. 3. ed. Rio de Janeiro: Elsevier, 2004. 813 p.

EVANS, H. E.; SACK, W. O. Prenatal development of domestic and laboratory mammals: growth curves, external features and selected references. Anatomia, Histologia, Embryologia, v. 2, p. 11-45, 1973.

FERRARA, N. Vascular endothelial growth factor: basic science and clinical progress. Endocrine Reviews, v. 25, n. 4, p. 581-611, 2004.

FERRARA, N.; CARVER-MOORE, K.; CHEN, H.; DOWD, M.; LU, L.; O'SHEA, K. S.; POWELL-BRAXTON, L.; HILLAN, K. J.; MOORE, M. W. Heterozygous embryonic lethality induced by targeted inactivation of the VEGF gene. Nature, v. 380, p. 439442, 1996.

FLORES, K. G., LI, J.; SEMPOWSKI, G. D.; HAYNES, B. F.; HALE, L. P. Analysis of the human thymic perivascular space during aging. Journal of Clinical Investigation, v. 104, p. 1031-1039, 1999.

FOURNIER, E.; BIRNBAUM, D.; BORG, J. P. Receptors for factors of the VEGF family. Cancer Bulletin, v. 84, p. 397-403, 1997. 
FRASER, C.; DONNELLY, C. A.; CAUCHEMEZ, S.; HANAGE, W. P.; VAN KERKHOVE, M. D.; HOLLINGSWORTH, T. D.; GRIFFIN, J.; BAGGALEY, R. F.; JENKINS, H. E.; LYONS, E. J.; JOMBART, T.; HINSLEY,W. R.; GRASSLY, N. C.; BALLOUX, F.; GHANI, A. C.; FERGUSON, N. M.; RAMBAUT, A.; PYBUS, O. G.; LOPEZ-GATELL, H.; ALPUCHE-ARANDA, C. M.; CHAPELA, L. B.; ZAVALA, E. P.; GUEVARA, D. M. E.; CHECCHI, F.; GARCIA, E.; HUGONNET, S.; ROTH, C. Pandemic potential of a strain of influenza $A(\mathrm{H} 1 \mathrm{~N} 1)$ : early findings. Science, v. 324, n. 5934, p. 1557-1561, 2009.

GABRILOVICH, D.; ISHIDA, T.; OYAMA, T.; RAN, S.; KRAVTSOV, V.; NADAF, S.; CARBONE, D. P. Vascular endothelial growth factor inhibits the development of dendritic cells and dramatically affects the differentiation of multiple hematopoietic lineages in vivo. Blood, v. 92, n. 11, p. 4150-4166, 1998.

GERBER, H. P.; CONDORELLI, F.; PARK, J.; FERRARA, N. Differential transcriptional regulation of the two vascular endothelial growth factor receptor genes. Flt-1, but not Flk-1/KDR, is up-regulated by hypoxia. The Journal of Biological Chemistry, v. 272, p. 23659-23667, 1997.

GOLDBERG, G. L.; ZAKRZEWSKI, J. L.; PERALES, M. A.; VAN DEN BRINK, M. R. Clinical strategies to enhance $T$ cell reconstitution. Seminars in Immunology, v. 19, p. 289-296, 2007.

GONÇALEZ, P. O.; CARNEIRO E SILVA, F. O.; SEVERINO, R. S.; DRUMMOND, S. S. Suprimento arterial do lobo torácico do timo em suínos da linhagem "Rezende". Ciencêcia Rural, v. 33, n.3, p. 501-505, 2003.

GORDON, J.; WILSON, V. A.; BLAIR, N.F.; SHERIDAN, J.; FARLEY, A.; WILSON, L.; MANLEY, N. R.; BLACKBURN, C. C. Functional evidence for a single endodermal origin for the thymic epithelium. Nature Immunology, v. 5, n. 5, p. 546-553, 2004.

GRAHAM, A.; SMITH A. Patterning the pharyngeal arches. Bioessays, v. 23, p. 54$61,2001$.

GRAY, D. H.; CHIDGEY, A. P.; BOYD, R. L. Analysis of thymic stromal cell populations using flow cytometry. Journal of Immunological Methods, v. 260, p. 15-28, 2002.

HALE, L. P.; BRAUN, R. D.; GWINN, W. M.; GREER, P. K.; DEWHIRST, M. W. Hypoxia in the thymus: role of oxygen tension in thymocyte survival. American Journal of Physiology. Heart and Circulatory Physiology, v. 282, p. 1467-1477, 2002. 
HALLMANN, R.; HORN, N.; SELG, M.; WENDLER, O.; PAUSCH, F.; SOROKIN, L. $M$. Expression and function of laminins in the embryonic and mature vasculature. Physiological Reviews, v. 85, p. 979-1000, 2005.

HANAHAN, D. Signaling vascular morphogenesis and maintenance. Science, v. 277, n. 5322, p. 48-50, 1997.

HEIN, W. R.; GRIEBEL, P. J. A road less travelled: large animal models in immunological research. Nature Reviews Immunology, v. 3, p. 79-84, 2003.

HILFER, S. R.; BROWN, J. W. The development of the pharyngeal endocrine organs in mouse and chick embryos (Part 4). Scan Electron Microscopy, p. 2009-2022, 1984.

HINCE, M.; SAKKAL, S.; VLAHOS, K.; DUDAKOV, J.; BOYD, R.; CHIDGEY, A. The role of sex steroids and gonadectomy in the control of thymic involution. Cellular Immunology, v. 252, n.1-2, p. 122-138, 2008.

HOLLÄNDER, G.; GILL, J.; ZUKLYS, S.; IWANAMI, N.; LIU, C.; TAKAHAMA, Y. Cellular and molecular events during the early thymus development. Immunological Reviews, v. 209, p. 28-46, 2006.

IKEDA, E.; ACHEN, M. G.; BREIER, G.; RISAU, W. Hypoxia-induced transcriptional activation and increased mRNA stability of vascular endothelial growth factor in C6 glioma cells. The Journal of Biological Chemistry, v. 270, n. 34, p. 19761-19766, 1995.

INTERNATIONAL COMMITTEE ON VETERINARY GROSS ANATOMICAL NOMENCLATURE. Nomina anatomica veterinaria. 5. ed. Hannover, Columbia, Gent, Sapporo, 2005. 190 p.

JOORY, K. D.; LEVICK, J. R.; MORTIMER, P. S.; BATES, D. O. Vascular endothelial growth factor-C (VEGF-C) expression in normal human tissues. Lymphatic Research and Biology, v. 4, n. 2, p. 73-82, 2006.

JOUKOV, V.; PAJUSOLA, K.; KAIPAINEN, A.; CHILOV, D.; LAHTINEN, I.; KUKK, E.; SAKSELA, O.; KALKKINEN, N.; ALITALO, K. A novel vascular endothelial growth factor, VEGF-C, is a ligand for the Flt4 (VEGFR-3) and KDR (VEGFR-2) receptor tyrosine kinases. EMBO Journal, v. 15, n. 9, p. 290-298, 1996. 
JUSSILA, L.; VALTOLA, R.; PARTANEN, T. A.; SALVEN, P.; HEIKKILAE, P.; MATIKAINEN, M. T.; RENKONEN, R.; KAIPAINEN, A.; DETMAR, M.; TSCHACHLER, E.; ALITALO, R.; ALITALO, K. Lymphatic edothelium and Kaposi's sarcoma spindle cells detected by antibodies against the vascular endothelial growth factor receptor-3. Cancer Research, v. 58, p. 1599-1604, 1998.

KASTSCHENKO, N. Das schicksal der embryonalen schlundspalten bei säugethieren. Archiv für Mikroskopische Anatomie, v. 30, n. 1, p. 1-26, 1887.

KATO, S. Thymic microvascular system. Microscopy Research and Technique, v. 38, p. 287-299, 1997.

KISELEVA, E. P.; KRYLOV, A. V.; LYUDYNO, V. I.; SUVOROV, A. N. Effect of VEGF on mouse thymocyte proliferation and apoptosis in vitro. Bulletin of Experimental Biology and Medicine, v. 139, n. 5, p. 576-579, 2005.

KLUG, B. D.; CARTER, C.; GIMENEZ-CONTI, I. B.; RICHIE, E. R. Cutting edge: thymocyte-independent and thymocyte-dependent phases of epithelial patterning in the fetal thymus. Journal of Immunology, v. 169, p. 2842-2845, 2002.

KONG, Y. Y.; BOYLE, W. J.; PENNINGER, J. M. Osteoprotegerin ligand: a common link between osteoclastogenesis, lymph node formation and lymphocyte development. Immunology and Cell Biology, v. 77, p. 188-193, 1999.

KÖNIG, H. E.; LIEBICH, H. G. Anatomia dos animais domésticos: texto e atlas colorido. Porto Alegre: Artmed, 2002. 292 p.

KURATANI, S. Craniofacial development and the evolution of the vertebrates: the old problems on a new background. Zoological Sciences, v. 22, p. 1-19, 2005.

LANGE, T.; GUTTMANN-RAVIV, N.; BARUCH, L.; MACHLUF, M.; NEUFELD, G. VEGF162, a new heparin-binding vascular endothelial growth factor splice form that is expressed in transformed human cells. Journal of Biological Chemistry, v. 278, n. 19, p. 17164-17169, 2003.

LEE, H. W.; KIM, B. S.; KIM, H. J.; LEE, C. W.; YOO H. J.; KIM, J. B.; YOON, S. Upregulation of receptor activator of nuclear factor-kB ligand expression in the thymic subcapsular, paraseptal, perivascular, and medullary epithelial cells during thymus regeneration. Histochemistry and Cell Biology, v. 123, p. 491-500, 2005.

LEE, H. W.; KIM, S. M.; SHIM, N. R.; BAE, S. K.; JUNG, I. G.; KWAK, J. Y.; KIM, B. S.; KIM, J. B.; MOON, J. O.; CHUNG, J. S.; YOON, S. Expression of nerve growth factor is upregulated in the rat thymic epithelial cells during thymus regeneration following acute thymic involution. Regulatory Peptides, v. 141, p. 86-95, 2007. 
LEPOSAVIĆ, G.; PERIŠIĆ, M. Age-associated remodeling of thymopoiesis: role for gonadal hormones and catecholamines. Neuroimmunomodulation, v. 15, p. 290322, 2008.

LEVY, A. P.; LEVY, N. S.; GOLDBERG, M. A. Post-transcriptional regulation of vascular endothelial growth factor by hypoxia. The Journal of Biological Chemistry, v. 271, n. 5, p. 2746-2753, 1996.

LÖWEN, G. L. Resultados do P76 suprême. Pen Ar Lan ao Vivo - Boletim Informativo da Genética Suína, n. 11, p. 2, 2009. Disponível em: <http://www.penarlan.com.br/download/ao Vivo11 julho-2009-web.pdf>. Acesso em: 10 ago. 2009.

MARIANO, M. Miniature swine (minipig) in biomedical experimental research: the Minipig br1. Acta Cirurgica Brasileira, v. 18, n. 5, p. 387-391, 2003.

MARODER, M.; BELLAVIA, D.; VACCA, A.; FELLI, M. P.; SCREPANTI, I. The thymus at the crossroad of neuroimmune interactions. Annals of the New York Academy of Science, v. 7, p. 917-741, 2000.

MANDARIM-DE-LACERDA, C. A. Métodos quantitativos em morfologia. Rio de Janeiro: EDUERJ, 1995. $131 \mathrm{p}$.

MANDARIM-DE-LACERDA, C. A. Stereological tools in biomedical research. Annals of the Brazilian Academy of Sciences, v. 75, n. 4, p. 469-486, 2003.

MANLEY, N. R.; BLACKBURN, C. C. A developmental look at thymus organogenesis: where do the non-hematopoetic cells in the thymus come from? Current Opinion in Immunology, v. 15, n. 2, p. 225-232, 2003.

MAYHEW, T. M. The new stereological methods for interpreting functional morphology from slices of cells and organs. Experimental Physilogy, v. 76, p. 639665, 1991.

MEHLE, A.; DOUDNA, J. A. Adaptive strategies of the influenza virus polymerase for replication in humans. Proceedings of the National Academy of Sciences of the United States of America, v. 106, n. 50, p. 21312-21316, 2009.

MESTAS, J.; HUGHES, C. C. W. Of mice and not men: differences between mouse and human immunology. Journal of Immunology, v. 172, n. 5, p. 2731-2738, 2004.

MIN, H.; MONTECINO-RODRIGUEZ, E.; DORSHKIND, K. Reassessing the role of growth hormone and sex steroids in thymic involution. Clinical Immunology, v. 118, p. 117-123, 2006. 
MÜLLER, S. M.; TERSZOWSKI, G.; BLUM, C.; HALLER, C.; ANQUEZ, V.; KUSCHERT, S.; CARMELIET, P.; AUGUSTIN, H. G.; RODEWALD, H. R. Gene targeting of VEGF-A in thymus epithelium disrupts thymus blood vessel architecture. Proceedings of the National Academy of Sciences of the United States of America, v. 102, n. 30, p. 10587-10592, 2005.

NAVEAU, Y. Qualidade da carne suína: importância real?. Pen Ar Lan ao Vivo Boletim Informativo da Genética Suína, n. 5, p. 1, 2006. Disponível em: $<$ http://www.penarlan.com.br/download/PAL¥Direct-5-2006.pdf>. Acesso em: 16 fev. 2009.

NAVEAU, Y. A importância econômica da prolificidade na genética fêmea. Pen Ar Lan ao Vivo - Boletim Informativo da Genética Suína, n. 7, p. 1, 2007. Disponível em: <http://www.penarlan.com.br/download/PAL AO VIVO 007 TODAS AS PAGS.pdf>. Acesso em: 16 fev. 2009.

NISHIO, H.; MATSUI, K.; TSUJI, H.; TAMURA, A.; SUZUKI, K. Immunolocalization of the mitogen-activated protein kinase signaling pathway in Hassall's corpuscles of the human thymus. Acta Histochemica, v. 103, n. 1, p. 89-98, 2001.

OLOFSSON, B.; PAJUSOLA, K.; KAIPAINEN, A.; VON EULER, G.; JOUKOV, V.; SAKSELA, O.; ORPANA, A.; PETTERSSON, R. F.; ALITALO, K.; ERIKSSON, U. Vascular endothelial growth factor $B$, a novel growth factor for endothelial cells. Proceedings of the National Academy of Sciences of the United States of America, v. 93, p. 2576-2581, 1996.

OLSEN, N. J.; VISELLI, S. M.; SHULTS, K.; STELZER, G.; KOVACS, W. J. Induction of immature thymocyte proliferation after castration of normal male mice. Endocrinology, v. 134, p. 107-113, 1994.

OLSSON, A. K.; DIMBERG, A.; KREUGER, J.; CLAESSON-WELSH, L. VEGF receptor signaling - in control of vascular function. Nature reviews. Molecular cell biology, v. 7, n. 5, p. 359-371, 2006.

OLSZEWSKA-PAZDRAK, B.; HEIN, T. W.; OLSZEWSKA, P.; CARNEY, D. H. Chronic hypoxia attenuates VEGF signaling and angiogenic responses by downregulation of KDR in human endothelial cells. American Journal of Physiology. Cell Physiology, v. 296, n. 5, p. 1162-1170, 2009.

ORTIZ-HIDALGO, C. Early clinical pathologists 5: The man behind Hassall's corpuscles. Journal of Clinical Pathology, v. 45, p. 99-10, 1992. 
PAAVONEN, K.; HORELLI-KUITUNEN, N.; CHILOV, D.; KUKK, E.; PENNANEN, S.; KALLIONIEMI, O.; PAJUSOLA, K.; OLOFSSON, B.; ERIKSSON, U.; JOUKOV, V.; PALOTIE, A.; ALITALO, K. Novel human vascular endothelial growth factor genes VEGF-B and VEGF-C localize to chromosomes $11 q 13$ and 4q34, respectively.

Circulation, v. 93, p. 1079-1082, 1996.

Park, H. J.; Kim, M. N.; Kim, J. G.; Bae, Y. H.; Bae, M. K.; Wee, H. J.; Kim, T. W.; Kim, B. S.; Kim, J. B.; Bae, S. K.; Yoon, S. Up-regulation of VEGF expression by NGF that enhances reparative angiogenesis during thymic regeneration in adult rat. Biochimica et Biophysica Acta, v. 1773, p. 1462-1472, 2007.

PATTEN, B. M. Embryology of the pig. 3. ed. New York: McGraw-Hill, 1948, p. 352.

PEARSE, G. Normal structure, function and histology of the thymus. Toxicologic Pathology, v. 34, p. 504-514, 2006.

PESIC, V.; RADOJEVIC, K.; KOSEC, D.; PLECAS-SOLAROVIC, B.; PERISIC, M.; LEPOSAVIC, G. Peripubertal orchidectomy transitorily affects age-associated thymic involution in rats. Brazilian Journal of Medical and Biological Research, v. 40, n. 11, p. 1481-1493, 2007.

PFAFFL, M. W. A new mathematical model for relative quantification in real-time RTPCR. Nucleic Acids Research, v. 29, n. 9, p. 2002-2007, 2001.

PHILIPS, H. S.; HAINS, J.; LEUNG, D. W.; FERRARA, N. Vascular indothelial growth factor is expressed in the rat corpus luteum. Endocrinology, v. 127, p. 965-967, 1990.

PLENDL, J. Angiogenesis and vascular regression in the ovary. Anatomia, Histologia, Embryologia, v. 29, n. 5, p. 257-266, 2000.

PROCKOP, S.; PETRIE, H. T. Cell migration and the anatomic control of thymocyte precursor differentiation. Seminars in immunology, v. 12, p. 435-444, 2000.

PUGH, C. W.; RATCLIFFE, P. J. Regulation of angiogenesis by hypoxia: role of the HIF system. Nature Medicine, v. 9, p. 677-684, 2003.

RAICA, M.; ENCICĂ, S.; MOTOC, A.; CÎMPEAN, A. M.; SCRIDON, T.; BÂRSAN, M. Structural heterogeneity and immunohistochemical profile of Hassall corpuscles in normal human thymus. Annals of Anatomy, v. 188, n. 4, p. 345-352.

RAMAKERS, C.; RUIJTER, J. M.; DEPREZ, R. H. L.; MOORMAN, A. F. M. Assumption-free analysis of quantitative real-time polymerase chain reaction (PCR) data. Neuroscience Letters, v. 339, p. 62-66, 2003. 
REZZANI, R.; BONOMINI, F.; RODELLA, L. F. Histochemical and molecular overview of the thymus as site for T-cells development. Progress in Histochemistry and Cytochemistry, v. 43, p. 73-120, 2008.

REYNOLDS, L. P.; REDMER, D. A. Angiogenesis in the placenta. Biology of Reproduction, v. 64, n. 4, p. 1033-1040, 2001.

RIBATTI, D.; VACCA, A.; NICO, B.; RIA, R.; DAMMACCO, F. Cross-talk between hematopoiesis and angiogenesis signaling. Current Molecular Medicine, v. 2, n. 6 , p. 537-543, 2002.

RODEN, A. C.; MOSER, M. T.; TRI, S. D.; MERCADER, M.; KUNTZ, S. M.; DONG, $\mathrm{H}$. Augmentation of T-cell levels and responses induced by androgen deprivation. Journal of Immunology, v. 173, p. 6098-6108, 2004.

ROTHKÖTTER, H. J.; SOWA, E.; PABST, R. The pig as a model of developmental immunology. Human \& Experimental Toxicology, v. 21, p. 533-536, 2002.

SACK, W. O. Part I: essentials of pig anatomy - head and neck. In: Pig anatomy and atlas. Ithaca, NY: Veterinary Textbooks, p. 3-15, 1982. 192 p.

SAVINO, W. The thymus is a common target organ in infectious diseases. PLoS Pathogens, v. 2, n. 6, p. 472-483, 2006.

SCHERLE W. A simple method for volumetry of organs in quantitative stereology. Mikroskopie, v. 26, p. 57-60, 1970.

SCHUMMER, A. Lymphatic system. In: NICKEL, R.; SCHUMMER, A. SEIFERLE, E. The anatomy of the domestic animals. Berlin: Varlag Paul Parey, 1981, v.3, p. 269-440.

SCHUURMAN, H. J.; KUPER, C. F.; KENDALL, M. D. Thymic microenvironment at the light microscopic level. Microscopy Research and Technique, v. 38, p. 216226, 1997.

SEMPOWSKI, G. D.; GOODING, M. E.; LIAO, H. X.; LE, P. T.; HAYNES, B. F. T cell receptor excision circle assessment of thymopoiesis in aging mice. Molecular Immunology, v. 38, p. 841-848, 2001.

SENGER, D. R.; PERRUZZI, C. A.; FEDER, J.; DVORAK, H. F. A highly conserved vascular permeability factor secreted by a variety of human and rodent tumor cell lines. Cancer Research, v. 46, n. 11, p. 5629-5632, 1986. 
SHARKEY, A. M.; DAY, K.; MCPHERSON, A.; MALIK, S.; LICENCE, D.; SMITH, S. K.; CHARNOCK-JONES, D. S. Vascular endothelial growth factor expression in human endometrium is regulated by hypoxia. The Journal of Clinical

Endocrinology and Metabolism, v. 85, n. 1, p. 402-409, 2000.

SILVA, F. O. C.; GONÇALEZ. P. O. Suprimento arterial da parte torácica do timo de fetos de suínos da raça Pietrain. In: ENCONTRO DE INICIAÇÃO CIENTÍFICA, 7., 1998, Uberlândia. Anais... Uberlândia: Universidade Federal de Uberlândia, 1998. p. 161

SINKORA, J.; REHAKOVA, Z.; SINKORA M.; CUKROWSKA, B.; TLASKALOVAHOGENOVA, H. Early development of immune system in pigs. Veterinary Immunology and Immunopathology, v. 87, p. 301-306, 2002.

SINKORA, M.; BUTLER, J. E.; HOLTMEIER, W.; SINKOROVA, J. Lymphocyte development in fetal piglets: facts and surprises. Veterinary Immunology and Immunopathology, v. 108, n. 1-2, p. 177-184, 2005.

SOKER, S.; TAKASHIMA, S.; MIAO, H. Q.; NEUFELD, G.; KLAGSBURN, M. Neuropilin-1 is expressed by endothelial and tumor cells as an isoform-specific receptor for vascular endothelial growth factor. Cell, v. 92, p. 735-745, 1998.

SOTTILE, J. Regulation of angiogenesis by extracellular matrix. Biochimica et Biophysica Acta, v. 1654, p. 13-22, 2004.

STEIN, I.; ITIN, A.; EINAT, P.; SKALITER, R.; GROSSMAN, Z.; KESHET, E. Translation of vascular endothelial growth Factor mRNA by internal ribosome entry: implications for translation under hypoxia. Molecular and Cellular Biology, v. 18, p. 3112-3119, 1998.

TAKASHIMA, S.; KITAKAZE, M.; ASAKURA, M.; ASANUMA, H.; SANADA, S.; TASHIRO, F.; NIWA, H., MIYAZAKI, J. J.; HIROTA, S.; KITAMURA, Y., KITSUKAWA, T.; FUJISAWA. H.; KLAGSBRUN, M.; HORI, M. Targeting of both mouse neuropilin-1 and neuropilin-2 genes severely impairs developmental yolk sac and embryonic angiogenesis. Proceedings of the National Academy of Sciences of the United States of America, v. 99, n. 6, p. 3657-3662, 2002.

TARBELL, K. V.; YAMAZAKI, S.; OLSON, K.; TOY, P.; STEINMAN, R. M. CD25+CD4+ T cells, expanded with dendritic cells presenting a single autoantigenic peptide, supress autoimmune diabetes. The Journal of Experimental Medicine, v. 199, n. 11, p. 1467-1477, 2004. 
TERMAN, B. I.; DOUGHER-VERMAZEN, M.; CARRION, M. E.; DIMITROV, D.; ARMELLINO, D. C.; GOSPODAROWICZ, D.; BOHLEN, P. Identification of the KDR tyrosine kinase as a receptor for vascular endothelial cell growth factor. Biochemical and Biophysical Research Communications, v. 187, n. 3, p. 1579-1586, 1992.

TIZARD, I. Órgãos do sistema imune. In: Introdução à imunologia veterinária. 6 . ed. São Paulo: Roca, 2000. p. 76-92.

TORRES-ROCA, J. F.; TUNG, J. W.; GREENWALD, D. R.; BROWN, J. M.; HERZENBERG, L. A.; HERZENBERG, L. A.; KATSIKIS, P. D. An early oxygendependent step is required for dexamethasone-induced apoptosis of immature mouse thymocytes. Journal of Immunology, v. 165, n. 9, p. 4822-4830, 2000.

TUMBLESON, M. E. Swine in biomedical research. New York: Plenum Press, 1986. 698 p.

VACKOVA, I.; UNGROVA, A.; LOPES, F. putative embryonic stem cell lines from pig embryos. Journal of Reproduction and Development, v. 53, n, 6, p. 1137-1149. 2007.

VAN DE WIJNGAERT, F. P.; KENDALL, M. D.; SCHUURMAN, H. J.; RADEMAKERS, H. P. M.; KATER, L. Heterogeneity of epithelial cells in the human thymus - an ultraestructural study. Cell and tissue Research, v. 237, p. 227-237, 1984.

VAN EWIJK, W. T-cell differentiation is influenced by thymic microenvironments. Annual Review of Immunology, v. 9, p. 591-615, 1991.

VAN EWIJK, W.; HOLLANDER, G.; TERHORST, C.; WANG, B. Stepwise development of thymic microenvironments in vivo is regulated by thymocyte subsets. Development, v. 127, p. 1583-1591, 2000.

VENZKE, W. G. Sistema Linfático em geral. In: GUETTY, R. Sisson/Grossman Anatomia dos animais domésticos. 5. ed. Rio de Janeiro: Guanabara Koogan, 1986. v, 1, p. 163-167.

VISELLI, S. M.; STANZIALE, S.; SHULTS, K.; KOVACS, W. J.; OLSEN, N. J. Castration alters peripheral immune function in normal male mice. Immunology, $v$. 84, p. 337-342, 1995.

WATANABE, N.; WANG, Y. H.; LEE, H. K.; ITO, T.; WANG, Y. H.; CAO, W.; LIU, Y. $J$. Hassall's corpuscles instruct dendritic cells to induce CD4+CD25+ regulatory $T$ cells in human thymus. Nature, v. 436, n. 7054, p. 1181-1185. 
WEIBEL, E. R. Stereological methods. Practical methods for biological morphometry. London: Academic Press, 1979. 415 p.

WINTHER, H.; AHMED, A.; DANTZER, V. Immunohistochemical localization of vascular endothelial growth factor (VEGF) and its two specific receptors, Flt-1 and KDR, in the porcine placenta and non-pregnant uterus. Placenta, v. 20, n. 1, p. 3543, 1999.

YAMASHITA, H.; KAMADA, D.; SHIRASUNA, K.; MATSUI, M.; SHIMIZU, T.; KIDA, K.; BERISHA, B.; SCHAMS, D.; MIYAMOTO, A. Effect of local neutralization of basic fibroblast growth factor or vascular endothelial growth factor by a specific antibody on the development of the corpus luteum in the cow. Molecular Reproduction and Development, v. 75, n. 9, p. 1449-1456, 2008.

YOON, S.; YOO, Y. H.; KIM, B. S.; KIM, J. J. Ultrastructural alterations of the cortical epithelial cells of the rat thymus after cyclophosphamide treatment. Histology and histopathology, v. 12, p. 401-413, 1997.

YOSHIDA, A.; ANAND-APTE, B.; ZETTER, B. R. Differential endothelial migration and proliferation to basic fibroblast growth factor and vascular endothelial growth factor. Growth Factors, v. 13, n. 1-2, p. 57-64, 1996.

ZAITSEVA, M.; KAWAMURA, T.; LOOMIS, R.; GOLDSTEIN, H.; BLAUVELT, A.; GOLDING, H. Stromal-derived factor 1 expression in the human thymus. Journal of Immunology, v. 168, n. 6, p. 2609-2617, 2002.

ZOTTERMAN, A. Die schweinthymus als eine thymus ecto-entodermalis.

Anatomischer Anzeiger, v. 38, p. 514-530, 1911. 